US Army Corps of Engineers ${ }_{\circledast}$

Engineer Research and

Development Center

Regional Sediment Management

\title{
Hydrodynamic and Sediment Transport Modeling for James River Dredged Material Management
}

Tahirih C. Lackey, Susan Bailey, Joseph Gailani, Sung-Chan Kim,

September 2020 and Paul Schroeder

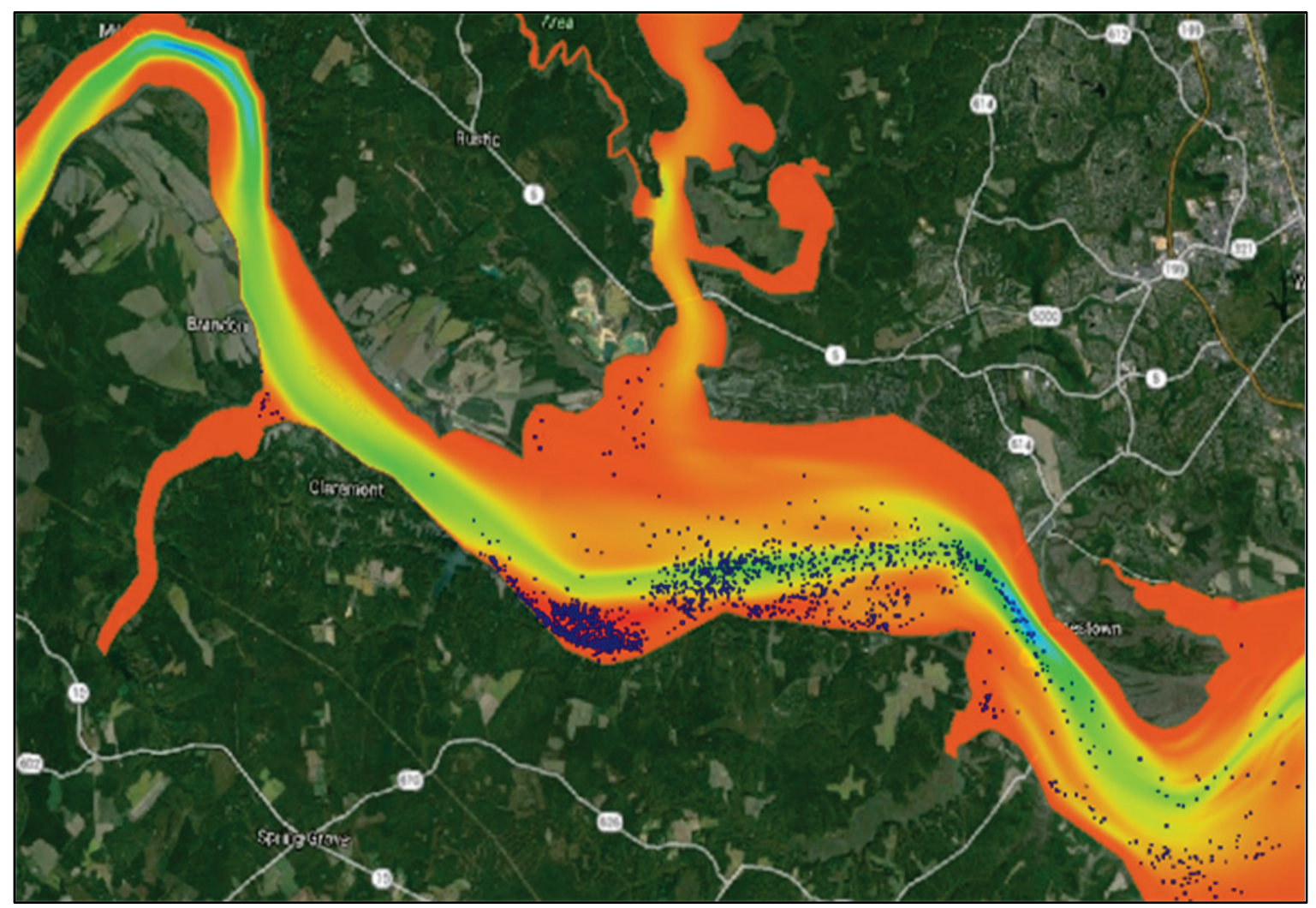


The US Army Engineer Research and Development Center (ERDC) solves the nation's toughest engineering and environmental challenges. ERDC develops innovative solutions in civil and military engineering, geospatial sciences, water resources, and environmental sciences for the Army, the Department of Defense, civilian agencies, and our nation's public good. Find out more at www.erdc.usace.army.mil.

To search for other technical reports published by ERDC, visit the ERDC online library at https://erdclibrary.on.worldcat.org/discovery. 


\section{Hydrodynamic and Sediment Transport Modeling for James River Dredged Material Management}

Tahirih C. Lackey, Joseph Gailani, and Sung-Chan Kim

Coastal and Hydraulics Laboratory

US Army Engineer Research and Development Center 3909 Halls Ferry Road

Vicksburg, MS 39180-6199

Susan Bailey and Paul Schroeder

Environmental Laboratory

US Army Engineer Research and Development Center 3909 Halls Ferry Road

Vicksburg, MS 39180-6199

Final report

Approved for public release; distribution is unlimited.

\footnotetext{
Prepared for US Army Corps of Engineers

Washington, DC 20314-1000

Under Project No, 448771; “James River Modeling”
} 


\section{Abstract}

The fate of material placed during dredging operations within the James River (Dancing Point-Swann Point reach) at a channel adjacent placement mound was modeled within this work. The study focuses on the potential migration of the placement mound into the channel as well as the transport of sediment resuspended during placement. A select combination of US Army Engineer Research and Development-developed models was utilized in this work to appropriately simulate hydrodynamic conditions, pipeline discharge near field suspended sediment estimates, far field transport of the pipeline discharge source term, and mound migration. Results show that the material released into the water column during placement remains in the placement area or is transported out of the area of interest downstream. A small fraction of sediment from the placement mound migrates into the channel after placement. The finegrained nature of these sediments precludes these small volumes of sediment from depositing in the channel where the currents are strong.

DISCLAIMER: The contents of this report are not to be used for advertising, publication, or promotional purposes. Citation of trade names does not constitute an official endorsement or approval of the use of such commercial products. All product names and trademarks cited are the property of their respective owners. The findings of this report are not to be construed as an official Department of the Army position unless so designated by other authorized documents. 


\section{Contents}

Abstract............................................................................................................. ii

Figures and Tables..............................................................................................................v

Preface ......................................................................................................... ix

1 Introduction .................................................................................................... 1

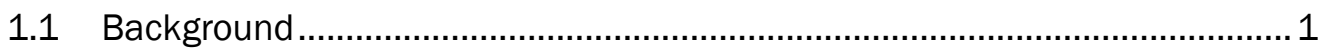

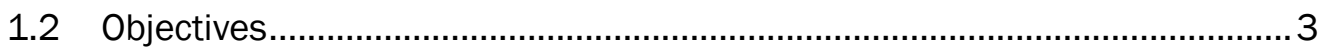

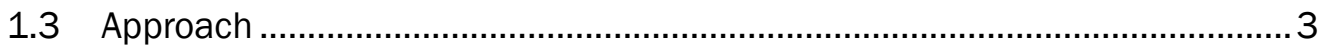

1.3.1 Curvilinear Hydrodynamic in 3-Dimensional (CH3D) (grid modification

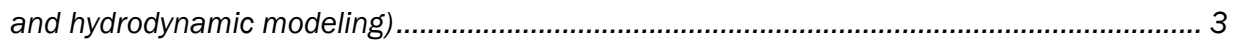

1.3.2 Continuous Discharge Fate (CDFATE) and related models (nearfield placement modeling) .................................................................................................... 3

1.3.3 Particle Tracking Model (PTM) (far field suspended loss transport

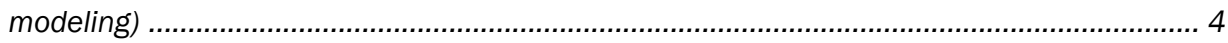

1.3.4 Longterm Fate (LTFATE) (morphology and overall mound transport).................... 4

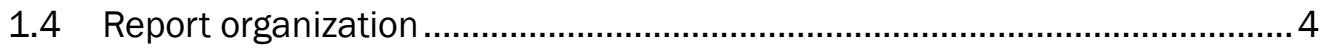

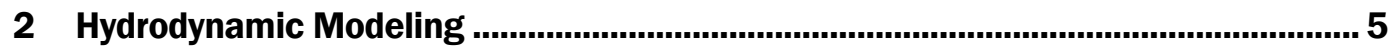

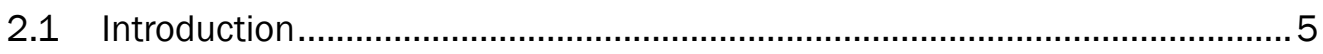

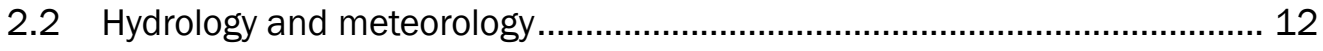

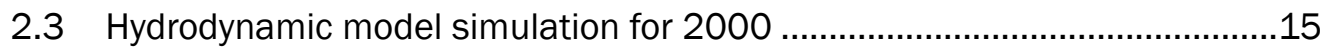

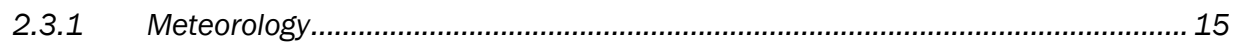

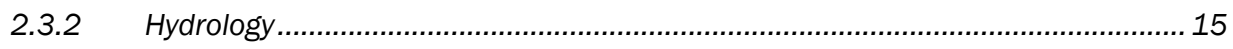

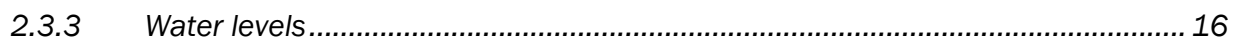

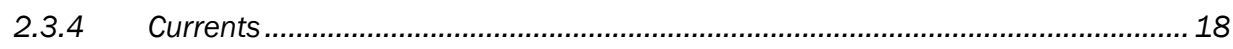

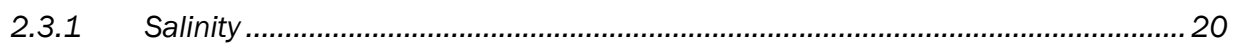

2.4 Summary and conclusion ............................................................... 22

3 Cohesive Sediment Transport Processes..............................................................23

3.1 Cohesive sediment transport processes............................................. 23

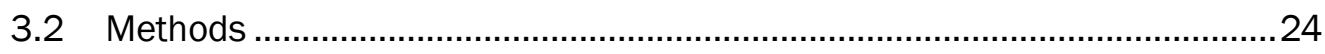

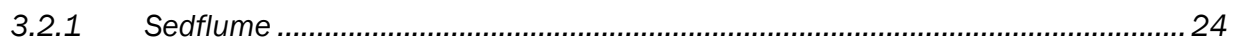

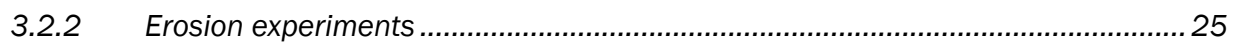

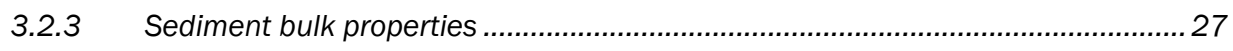

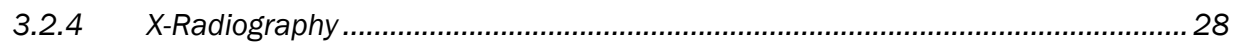

3.2.5 Multivariate erosion rate prediction............................................................... 32

3.3 Results and discussion .............................................................. 33

3.3.1 Core sample preparation ......................................................................................... 33

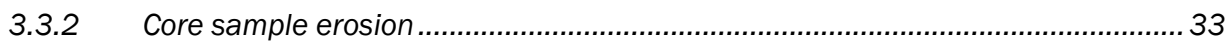

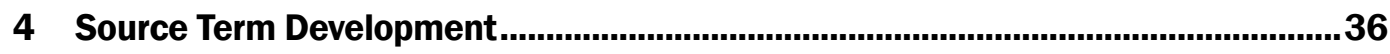

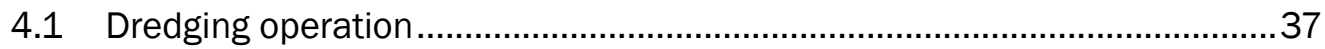




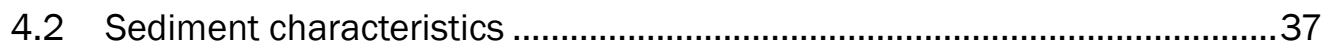

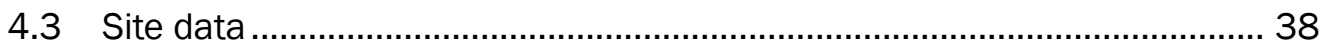

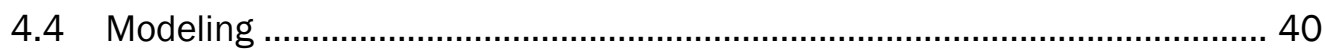

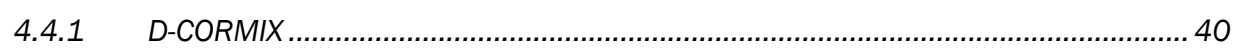

4.4.2 Dlsposal From a Continuous Discharge (DIFCD ...............................................41

4.4.3 DREDGE

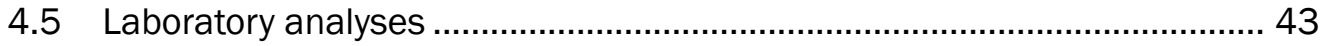

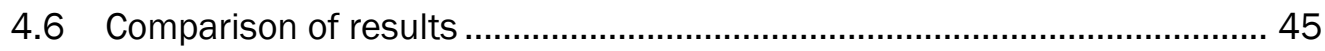

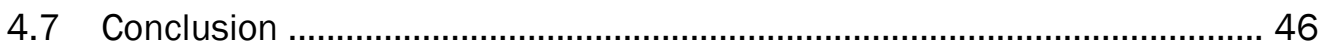

5 Far-Field Suspended Loss Transport Modeling (PTM Modeling) ............................47

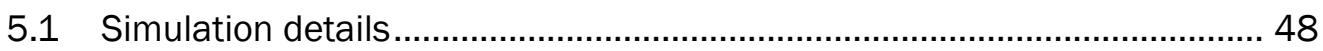

5.2 Source characterization ...................................................................... 49

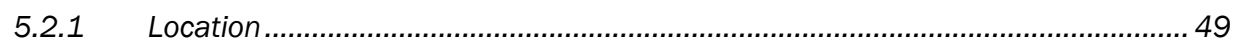

5.2.2 Hydrodynamics...................................................................................... 49

5.2.3 Sediment characterization ............................................................................. 50

5.2.4 Source strength.............................................................................................. 53

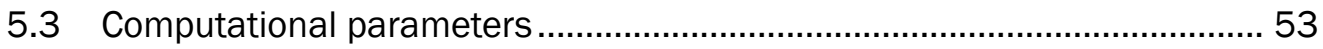

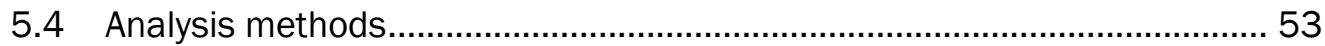

5.4.1 Calculation of suspended sediment concentration .............................................54

5.4.2 Calculation of depth of deposited sediment....................................................54

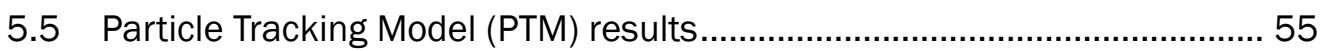

5.5.1 Suspended sediment concentration ..................................................................55

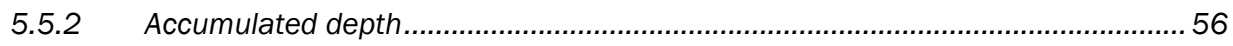

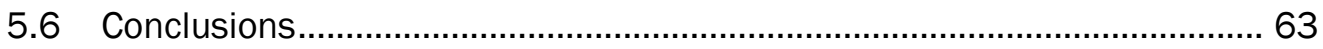

6 Morphology and Overall Mound Transport (LTFATE Modeling)...............................64

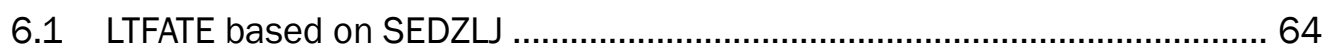

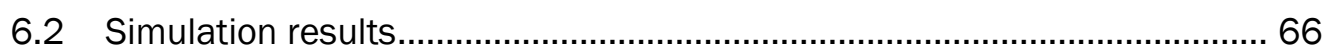

6.3 Summary and discussion ................................................................ 84

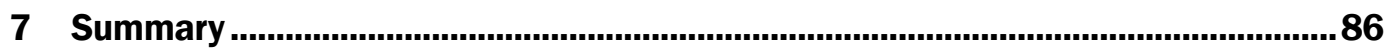

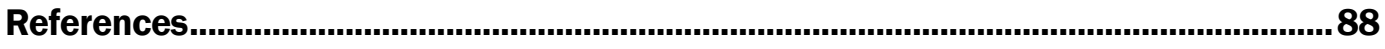

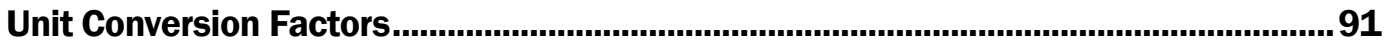

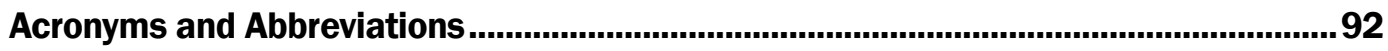

Report Documentation Page 


\section{Figures and Tables}

\section{Figures}

Figure 1-1. Site description.

Figure 2-1. Geophysical Scale Multi-Block modeling system

Figure 2-2. Grid for the existing Chesapeake Bay Water Quality model grid (Kim 2013).

Figure 2-3. Grids for the existing bay WQ model grid (blue) and the new grid (red) portion of Dancing Point - Swann Point Channel.

Figure 2-4. ADCIRC model grid.

Figure 2-5 MB grids for the James River and the adjoining Chesapeake Bay. Different colors represent different grid blocks. Also shown is the ADCIRC grid (red line) adjacent to the MB model domain

Figure 2-6. Fourteen grid blocks for the James River.

Figure 2-7. Grid block for Dancing Point - Swann Point reach of the James River (cyan). Upstream block reaches to Richmond (green). Also shown is a downstream block (gray).

Figure 2-8. Grids following navigation channel for Dancing Point-Swann Point reach.

Figure 2-9. Tide gage locations for James River.

Figure 2-10. Selected Chesapeake Bay Program long-term monitoring stations for the James River and adjoining Chesapeake Bay.

Figure 2-11. Hydrological, hydrodynamic, and meteorological conditions for 2010. Top panel is for fresh water discharge from James River and Appomattox River. Second panel is the water level records at Chesapeake Bay Bridge Tunnel (CBBT) tide gage location. Third and fourth panels represent wind speed and direction recorded at CBBT.

Figure 2-12. Freshwater discharge to the Chesapeake Bay (source: US Geological Survey [USGS]).

Figure 2-13. Freshwater discharges from the James River and the Appomattox River (source USGS).

Figure 2-14. Progress of an extratropical low-pressure system during a 1-day event in January 2000.

Figure 2-15. Freshwater discharge rate from the James River in 2000 (source: USGS).

Figure 2-16. Water levels at Sewells Point. Red plus sign represents the observation from the National Oceanic and Atmospheric Administration (NOAA) tide gage while the blue line represents the simulation.

Figure 2-17. M2 tide phase and amplitude along the James River. HAMELS was used for 2000 simulation data and compared with NOAA tide tables.

Figure 2-18. Drogue survey data. Solid blue line represents flood phase while red dotted lines represent ebb phase. The data covers 28 October 2000 to 09 November 2000. 
Figure 2-19. Average surface currents during ebb in 18 October 2000 from simulation.

Figure 2-20. Average surface currents during flood in 18 October 2000 from simulation.

Figure 2-21. Time series of surface (red) and bottom (blue) salinity at selected Chesapeake Bay Program (CBP) long-term monitoring stations along the James River. Lines represent simulation, and the circles are from CBP monitoring data.

Figure 3-1. Sedflume erosion flume (lower right). Core inserted into test section (upper left). Core surface flush with bottom of flow channel (upper right). Table of shear stress associated with channel flow rates (lower left).

Figure 3-2. Diagram of sediment core erosion process. The brown arrow indicates direction of motion of the sediment into the flume as the screw jack is advanced.

The blue arrow indicates flow direction of water.

Figure 3-3. Grain size data for samples extracted from original slurry. ............................ 31

Figure 3-4. Density profile for a core consolidated for 3 days.

Figure 3-5. Erosion data for Station $\mathrm{CHO} 2$ showing increasing erosion resistance with depth up to $9 \mathrm{~cm}$ below the original sediment/water interface due to increasing density. Erosion is relatively constant below $9 \mathrm{~cm}$ (within measurement error) because bed density is constant. 35

Figure 4-1. Pipeline placement at James River (photo by NAO). 36

Figure 4-2. Locations along James River selected for modeling. .39

Figure 4-3. Total sediment mass flux remaining as predicted by D-CORMIX. 40

Figure 4-4. Discharged solids remaining at distances downstream of the discharge from Point 2

Figure 4-5. Discharged solids remaining at distances downstream of the discharge from Point 3.

Figure 4-6. Mass of solids remaining in suspension as predicted by DREDGE model calculations.

Figure 4-7. Fraction solids (mass) remaining in water column during small-scale column settling test.

Figure 4-8. Fraction solids (mass) remaining in water column after pumping sediment slurry into $1.6 \mathrm{ft}$ of water.

Figure 5-1. Initial source locations for PTM simulations.

Figure 5-2. Hydrodynamic conditions at source locations. 50

Figure 5-3. PTM dataset analysis grid.

Figure 5-4. Suspended sediment concentration at P2 after (A) 1 day, (B) 1 week, (C) 2 weeks, and (D) 1 month.

Figure 5-5. Suspended sediment concentration at P4 after (A) 1 day, (B) 1 week, (C) 2 weeks, and (D) 1 month. 58

Figure 5-6. Suspended sediment concentration at P6 after (A) 1 day, (B) 1 week, (C) 2 weeks, and (D) 1 month.

Figure 5-7. Deposition depth at P2 after after (A) 1 day, (B) 1 week, (C) 2 weeks, and (D) 1 month. 
Figure 5-8. Deposition depth at P4 after after (A) 1 day, (B) 1 week, (C) 2 weeks, and (D) 1 month.

Figure 5-9. Deposition depth at P6 after after (A) 1 day, (B) 1 week, (C) 2 weeks, and (D) 1 month.

Figure 6-1. Distribution map for core types.

Figure 6-2. Location of navigation channel (red) and placement mound (marked by blue line) on computational grid blocks 1 (green), 2 (orange), and 3 (cyan).

Figure 6-3. Hydrodynamics and bed evolution-from top to bottom (a) freshwater discharge from James River, (b) simulated water levels in the navigation channel, (c) magnitude of mean bottom velocities in the channel, and (d) mean bed elevation deviations from initial bed at the mound (red) and the channel (blue).

Figure 6-4. Bottom suspended sediment concentration $\left(\mathrm{g} / \mathrm{cm}^{3}\right)$ during flood at 4/8 03:00 and 4/8 04:00.

Figure 6-5. Bottom suspended sediment concentration $\left(\mathrm{g} / \mathrm{cm}^{3}\right)$ during flood at 4/8 05:00 and 4/8 06:00

Figure 6-6. Bottom suspended sediment concentration $\left(\mathrm{g} / \mathrm{cm}^{3}\right)$ during flood at 4/8 07:00 and 4/8 08:00.

Figure 6-7. Bedload concentration $\left(\mathrm{g} / \mathrm{cm}^{3}\right)$ during flood at $4 / 8$ 03:00 and 4/8 04:00.

Figure 6-8. Bedload concentration $\left(\mathrm{g} / \mathrm{cm}^{3}\right)$ during flood at $4 / 8$ 05:00 and 4/8 06:00

Figure 6-9. Bedload concentration $\left(\mathrm{g} / \mathrm{cm}^{3}\right)$ during flood at 4/8 07:00 and 4/8 08:00.

Figure 6-10. Bottom suspended sediment concentration $\left(\mathrm{g} / \mathrm{cm}^{3}\right)$ during ebb at 4/8 05:00 and 4/8 06:00 .

Figure 6-11. Bottom suspended sediment concentration $\left(\mathrm{g} / \mathrm{cm}^{3}\right)$ during ebb at 4/8 12:00 and 4/8 13:00

Figure 6-12. Bottom suspended sediment concentration $\left(\mathrm{g} / \mathrm{cm}^{3}\right)$ during ebb at 4/8 14:00 and 4/8 15:00.

Figure 6-13. Bedload concentration $\left(\mathrm{g} / \mathrm{cm}^{3}\right)$ during ebb at $4 / 810: 00$ and $4 / 8$ 11:00.

Figure 6-14. Bedload concentration $\left(\mathrm{g} / \mathrm{cm}^{3}\right)$ during ebb at 4/8 12:00 and 4/8 13:00

Figure 6-15. Bedload concentration $\left(\mathrm{g} / \mathrm{cm}^{3}\right)$ during ebb at 4/8 14:00 and 4/8 15:00.

Figure 6-16. Bed thickness change $(\mathrm{cm})$ during flood at 4/8 05:00 and 4/8 06:00.

Figure 6-17. Bed thickness change $(\mathrm{cm})$ during ebb at 4/8 12:00 and 4/8 13:00..........82

Figure 6-18. Sediment mass $\left(\mathrm{g} / \mathrm{cm}^{2}\right)$ in the bed layers at the end of the simulation period.

Figure 6-19. Net gain of sediments in the bed per unit area at final stage. 


\section{Tables}

Table 2-1. Top seven harmonic constituents at CBBT (NOAA Gage 8638863).

Data source -

http://tidesandcurrents.noaa.gov/harcon.html?unit=0\&timezone=0\&id=8638863\&name=

Chesapeake+Bay+Bridge+Tunnel\&state=VA .................................................................. 17

Table 3-1. Grain size distribution results..................................................................... 32

Table 3-2. Values of parameters in Equation 3-6 for James River dredged

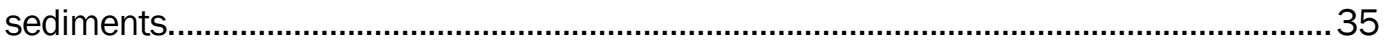

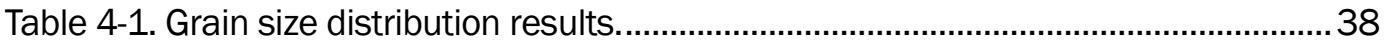

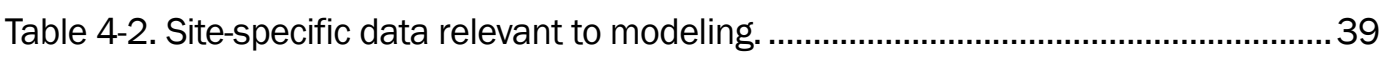

Table 4-3. Particle settling velocity applied to the DREDGE model for each size

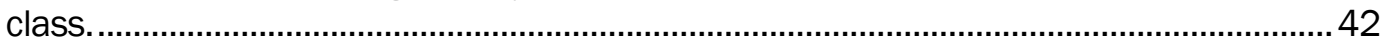

Table 4-4. Percent solids remaining predicted by laboratory tests and different

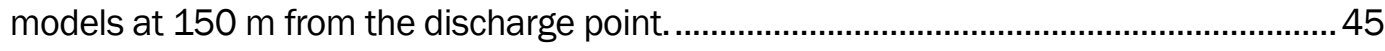

Table 4-5. Mass source description for discharge at each location....................................46

Table 5-1. Details of dredging operations...................................................................... 48

Table 5-2. PTM Source sediment grain size description. ...................................................... 51

Table 5-3. PTM Computational runtime parameters. ......................................................53

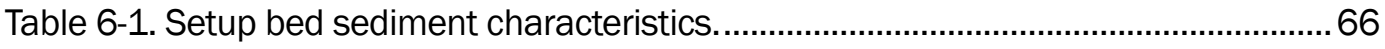




\section{Preface}

This study was conducted for Headquarters, US Army Corps of Engineers, under Project Number 448771, "James River Modeling." This study was conducted as part of the Regional Sediment Management program under the direction of Dr. Katherine Brutsché, Program Manager.

The work was performed by the Coastal Processes Branch of the Flood and Storm Protection Division, US Army Engineer Research and Development Center, Coastal and Hydraulics Laboratory (ERDC-CHL), and Environmental Engineering Branch of the Environmental Processes and Engineering Division, ERDC, Environmental Laboratory (EL). At the time of publication of this report, Ms. Ashley Frey was Chief, Coastal Process Branch; Dr. Cary Talbot was Chief, Flood and Storm Protection Division; and Mr. Charles E. Wiggins was the Technical Director for Navigation. The Deputy Director of ERDC-CHL was Mr. Jeffrey R. Eckstein, and the Director was Dr. Ty V. Wamsley. Dr. W. Andy Martin was Chief, Environmental Branch, and Mr. Warren Lorentz was Chief, Environmental Processes and Engineering Division. Dr. Brandon Lafferty was Deputy Director of ERDC-EL, and Dr. Jack E. Davis was the Director.

Appreciation is expressed for the following: the contribution of Mr. Robert Pruhs from the Norfolk District, who provided data and sitespecific information regarding the study area; the personnel of the Field Data Collection and Analysis Branch of the CHL, who assisted with the analysis of the sediment samples; and the assistance and funding from the Regional Sediment Management Program, which allowed the completion of this work.

At the time of publication of this report, COL Teresa Schlosser was the Commander of ERDC, and Dr. David Pittman was the Director. 


\section{Introduction}

\subsection{Background}

The James River Federal Navigation Project was congressionally authorized by the River and Harbors Act of 5 July 1884 and modified by the River and Harbor Act of 13 June 1902, 3 March 1905, 3 July 1930, 26 August 1937, 2 March 1945, 17 May 1950, and 23 October 1962. The federal navigation channel in the James River runs from Hampton Roads to Richmond, Virginia, a distance of approximately 90 miles. The project provides for a channel $35 \mathrm{ft}^{*}$ deep and $300 \mathrm{ft}$ wide from Hampton Roads to Richmond Deepwater Terminal, approximately 86 miles in length. However, the channel is currently maintained to a dredging depth of $28 \mathrm{ft}$ and $300 \mathrm{ft}$ wide. The Dancing Point - Swann Point Channel is located in the middle James River between Dancing Point and Glass House Point with James City County to the north and Surry County to the south. The channel segment is approximately 7.5 miles in length and requires maintenance dredging annually to maintain safe navigable depths. The Norfolk District removes between 300,000 to 600,000 cy of sediment from the channel each year. Dredged material is placed at an authorized (i.e., permitted) overboard placement site located parallel to the channel using pipeline placement. The centerline of the overboard placement site is approximately 6.5 miles in length and is generally located approximately $2,200 \mathrm{ft}$ south of the channel (Figure 1-1).

\footnotetext{
* For a full list of the spelled-out forms of the units of measure used in this document, please refer to US Government Publishing Office Style Manual, 31st ed. (Washington, DC: US Government Publishing Office 2016), 248-52, https://www.govinfo.gov/content/pkg/GPO-STYLEMANUAL-2016/pdf/GPOSTYLEMANUAL-2016.pdf.
} 
Figure 1-1. Site description.

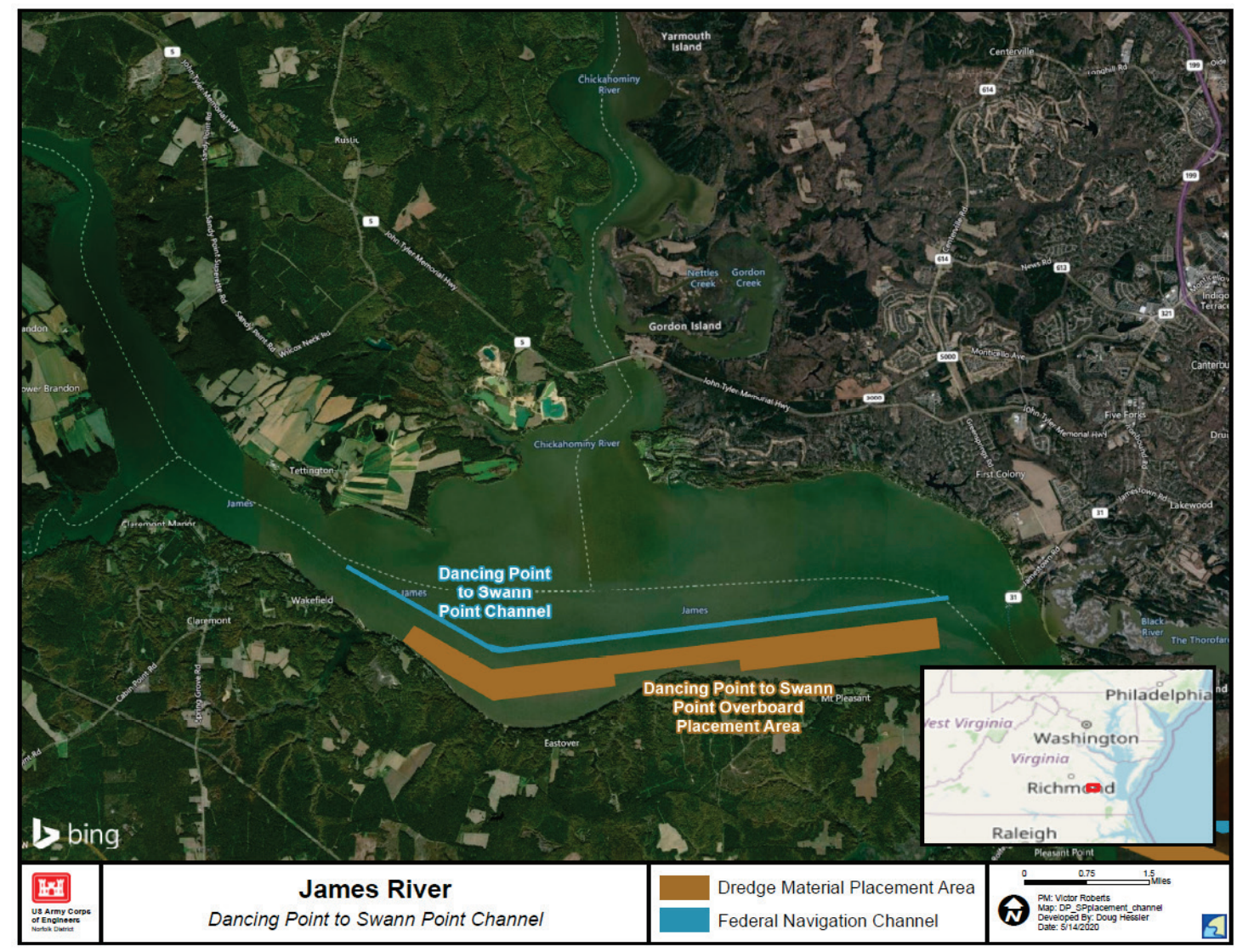

Increased dredging costs over recent years along with Operations and Maintenance budget cuts have decreased the amount of dredging that can be accomplished to maintain the navigation project to meet navigation needs and the goal of unrestricted navigation on the James River. Modeling of the fate of sediments dredged from the channel may assist in dredged material management at the site to optimize the placement of the dredged material and evaluate shoaling rates and contribute to the sediment budget development using the Sediment Budget Analysis System software (Rosati and Kraus 1999).

The Norfolk District-Operations Branch recently renewed the Virginia Marine Resources Commission (VMRC) subaqueous permit for encroachments on state-owned bottomlands for overboard placement of dredged material in the James River. One condition of the VMRC permit requires the US Army Corps of Engineers (USACE) to "...report on the fate of the disposal material (DM)...." To meet this condition in the permit, the proposed work effort will use the recent Tribell Shoals Channel DM modeling effort by the US Army Engineer Research and Development 
Center as a framework for evaluating the fate of the dredged material from Dancing Point - Swann Point Channel and its placement operations. To accomplish the task of modeling the transport of dredged material, several models will be used.

\subsection{Objectives}

The purpose of this study is to predict the fate of dredged material placed in the Dancing Point - Swann Point reach of the James River. This study focuses on the potential migration of the placement mound into the channel as well as the transport of sediment resuspended during placement.

\subsection{Approach}

The following numerical models will be used to predict transport in the James River.

\subsubsection{Curvilinear Hydrodynamic in 3-Dimensional (CH3D) (grid modification and hydrodynamic modeling)}

The $\mathrm{CH}_{3} \mathrm{D}$-WES (Curvilinear Hydrodynamic in three-dimensional (3D), Waterways Experiment Station) (Chapman et al. 1996) model solves 3D Reynolds-averaged, Boussinesq approximated, Navier-Stokes equations. It is a finite difference model and involves two major manipulations: mode splitting for internal and external mode transport and boundary fitted grid in horizontal dimension. The equations are transformed to fit the curvilinear non-orthogonal grid in horizontal plane.

The model has been applied to the Chesapeake Bay for Chesapeake Bay Water Quality Model (Cerco et al. 2010) and the James River for Tribell Shoal dredged material displacement study. The model also uses a multiblock (MB) version of $\mathrm{CH}_{3} \mathrm{D}$-WES (Chapman and Luong 2009), which enables high-resolution computational domains without an excessive burden of execution time.

\subsubsection{Continuous Discharge Fate (CDFATE) and related models (nearfield placement modeling)}

When dredged material is discharged into a receiving water body, a plume will form. The size, location, and movement of the plume in the water column, and hence the impact on the receiving water, can be estimated using the CDFATE model (Chase 1994; Havis Environmental 1994) and its component models (Dredging Cornell Mixing Model D-CORMIX [Doneker et al. 2004] and DIsposal From a Continuous Discharge [DIFCD] [Johnson 1990; Brandsma and Divoky 1976]). These models can be used 
to determine the extent of the mixing zone, that is, that area in the immediate vicinity of the discharge point where water quality (WQ) parameters may exceed established criteria. Information that characterizes the receiving water environment and the dredged material disposal method is provided to the model. The model uses these data in concert with numerical computations to generate information describing the plume location, plume geometry, and concentration of sediment within the plume as a function of time. Additionally, if needed, the Pipeline Disposal Fate model can provide a description of the deposition movement and spreading on the sediment bed.

\subsubsection{Particle Tracking Model (PTM) (far field suspended loss transport modeling)}

The PTM is a Lagrangian particle tracker designed to simulate particle transport processes (MacDonald et al. 2006; Lackey and Smith 2008; Gailani et al. 2016). PTM has been developed for application to dredging and coastal projects including dredged material dispersion and fate, sediment pathway and fate, and constituent transport. The model contains algorithms that appropriately represent transport, settling, deposition, mixing, and resuspension processes in nearshore wave/current conditions. It uses waves and currents developed through other models as input to PTM forcing functions.

\subsubsection{Longterm Fate (LTFATE) (morphology and overall mound transport)}

Longterm Fate (LTFATE) (Hayter et al. 2012) is a site evaluation tool that estimates the dispersion characteristics of a dredged material placement site over long periods of time, ranging from days for storm events to a year or more for ambient conditions. Simulations are based on the use of local wave and current condition input. LTFATE has the capability of simulating both non-cohesive and cohesive sediment transport. In addition, morphology change and consolidation are accounted for to accurately predict physical processes occurring at the site.

\subsection{Report organization}

Chapter 2 of this report describes the hydrodynamic modeling performed for this work. In Chapter 3, cohesive sediment processes are explained as part of the field data analysis. Chapter 4 describes the nearfield sediment transport and source term development for PTM. In Chapters 5 and 6, modeling results for the transport of sediment using PTM and LTFATE are presented, respectively. 


\section{Hydrodynamic Modeling}

\subsection{Introduction}

The Geophysical Scale Multi-Block (GSMB) Transport Modeling System is composed of multiple process models as shown in Figure 2-1. It is shown that USACE-accepted wave, hydrodynamic, sediment and WQ transport models are both directly and indirectly linked within the GSMB framework.

Figure 2-1. Geophysical Scale Multi-Block modeling system.

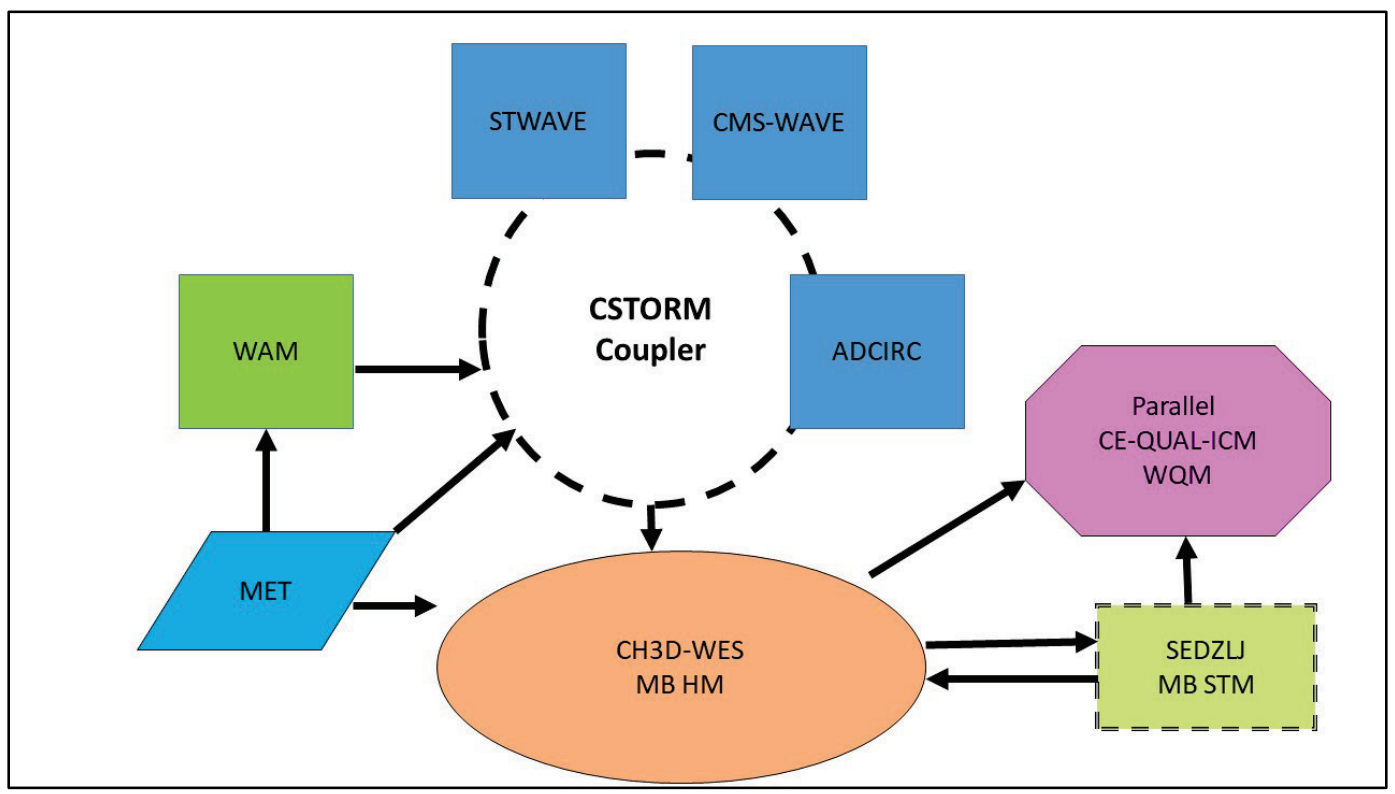

The components of GSMB are the two-dimensional (2D) deep water Wave Model (Komen et al. 1994; Jensen et al. 2012), data from meteorological model MET (e.g., Saha et al. 2010 http://journals.ametsoc.org/doi/pdf/10.1175/2010BAMS3001.1), shallow water wave models STWAVE (Smith et al. 1999), CMS-WAVE (Lin et al. 2008), the large scale unstructured 2D ADCIRC hydrodynamic model (http://www.adcirc.org) and the regional scale models Curvilinear Hydrodynamics in Three Dimension ( $\left.\mathrm{CH}_{3} \mathrm{D}\right)-\mathrm{MB}$ (Luong and Chapman 2009), which is the $\mathrm{MB}$ version of $\mathrm{CH}_{3} \mathrm{D}-\mathrm{WES}$ (Chapman et al. 1996; Chapman et al. 2009), MB CH3D-SEDZLJ sediment transport model (Hayter et al. 2012) and CE-QUAL Management -ICM WQ model (Bunch et al. 2003; Cerco and Cole 1994). 
Cerco et al. (2010) developed a 3D Chesapeake Bay WQ model, CE-QUALICM in which the transport mechanism is provided by $\mathrm{CH}_{3} \mathrm{D}$-WES z-grid version. Cerco et al. (2010) subsequently extended the WQ model for suspended solids management. To include bed response to exerted bottom shear stresses, Harris et al. (2010, 2012) developed a scheme based on bottom boundary layer dynamics. Kim (2013) presented the evaluation of the $3 \mathrm{D}$ hydrodynamics portion of the WQ model.

The original bay WQ model included the extent of James River as well as the other major tributaries to the Chesapeake Bay. The resolution was optimized for WQ management (Figure 2-2). The project Dancing Point Swann Point Channel was represented by approximately $1000 \mathrm{~m} \times 200 \mathrm{~m}$ grid cells in the WQ mode (Figure 2-3). In this study, a new grid is formed to represent the channel for sediment transport in which a typical channel is represented by $300 \mathrm{~m} \times 30 \mathrm{~m}$ grid. 
Figure 2-2. Grid for the existing Chesapeake Bay Water Quality model grid (Kim 2013).

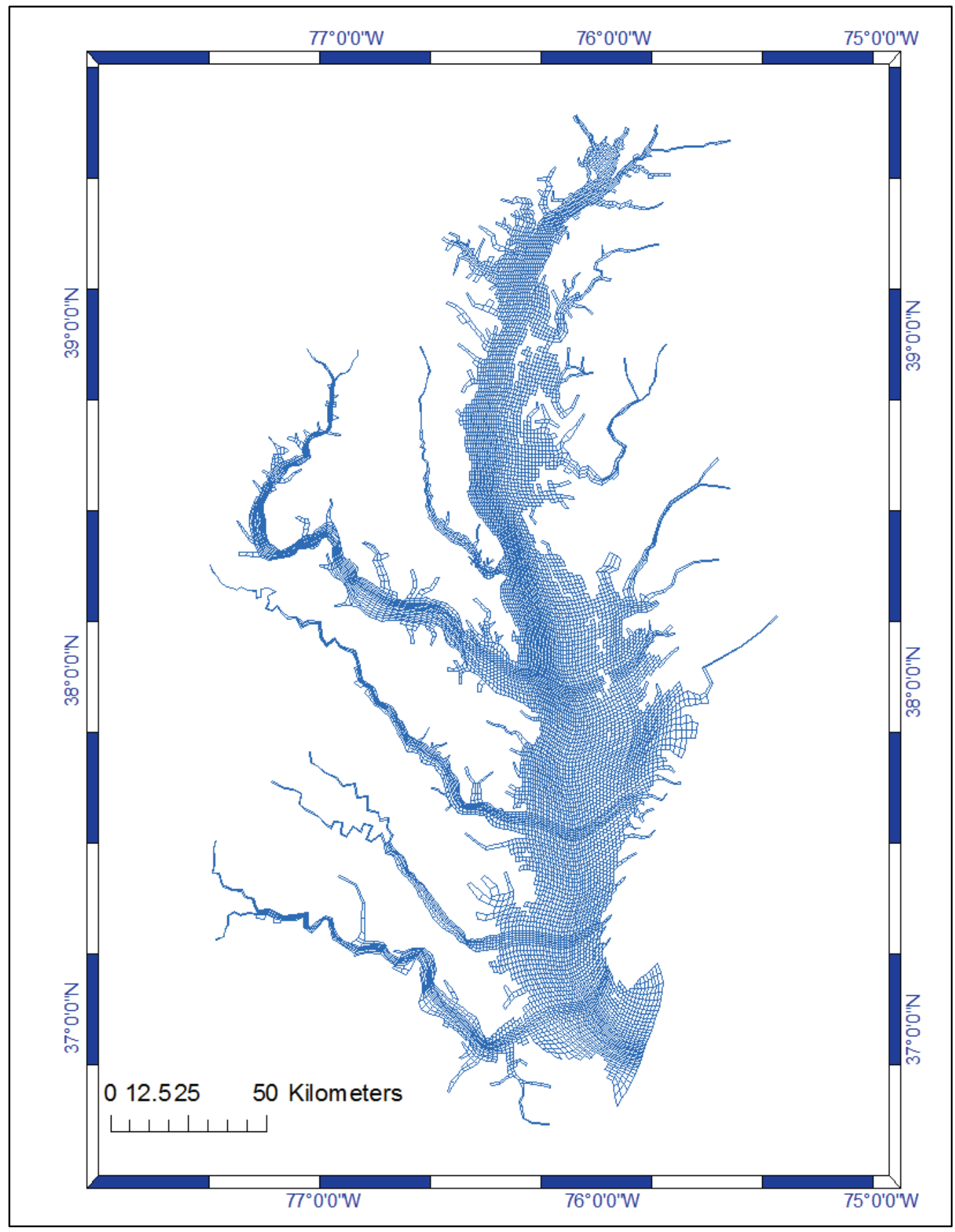


Figure 2-3. Grids for the existing bay WQ model grid (blue) and the new grid (red) portion of Dancing Point - Swann Point Channel.

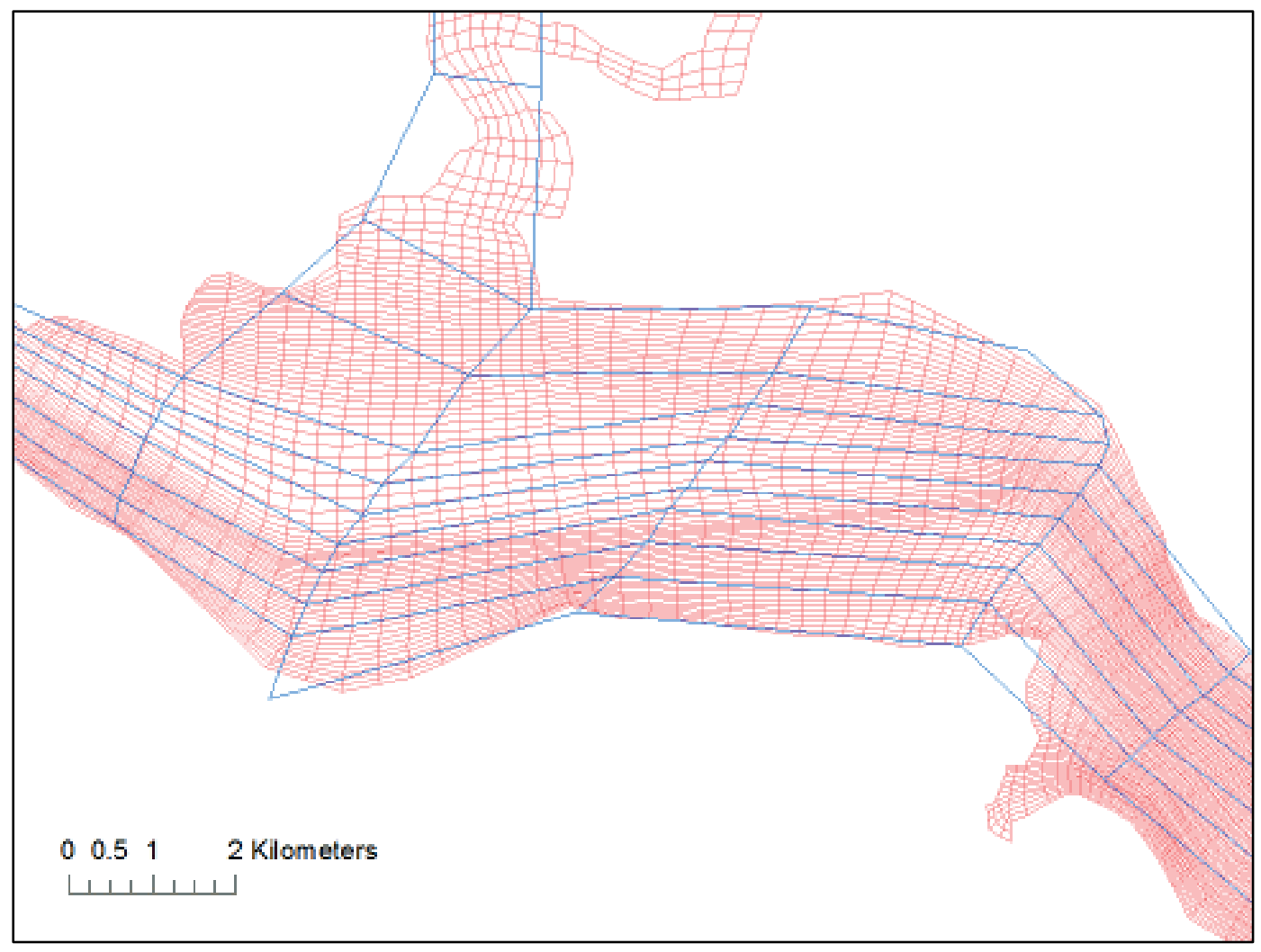

Hydrodynamic modeling of the James River follows the GSMB framework in which multiple block grids were constructed and water levels at the open boundary off the Chesapeake Bay was forced by ADCIRC model. The ADCIRC model application used to derive the water level at open boundary conditions of $\mathrm{CH}_{3} \mathrm{D}$ model uses a grid covering the western Atlantic Ocean and Gulf of Mexico off the East Coast of the United States with 60487 nodes (Figure 2-4) (Hagen et al. 2000).

A total of 17 grid blocks were generated in the GSMB framework to represent the James River and adjoining Chesapeake Bay (Figure 2-5). Out of these, 14 grid blocks cover the James River (Figure 2-6). Figure 2-7 shows the grids around the project area between Dancing Point and Swann point. For the grid block for Dancing Point - Swann Point reach, grids were built to represent the navigation channel (Figure 2-8). The navigation channel is represented by grid with approximately $20 \mathrm{~m}$ in width and $300 \mathrm{~m}$ in length. Figures 2-9 and 2-10 show tide gage locations and temperature-salinity locations used for validation of the hydrodynamics for this study. 
Figure 2-4. ADCIRC model grid.

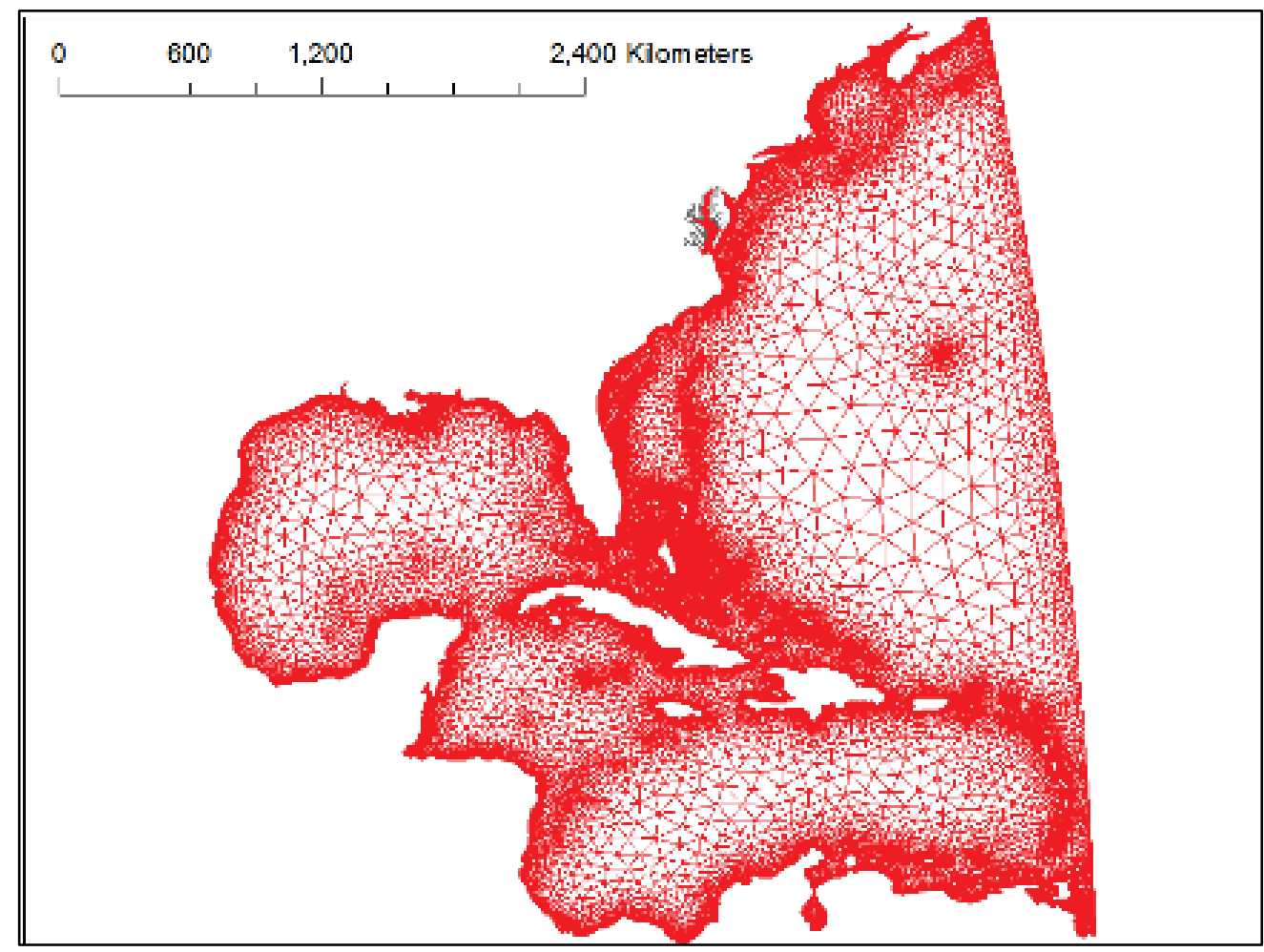

Figure 2-5 MB grids for the James River and the adjoining Chesapeake Bay. Different colors represent different grid blocks. Also shown is the ADCIRC grid (red line) adjacent to the MB model domain.

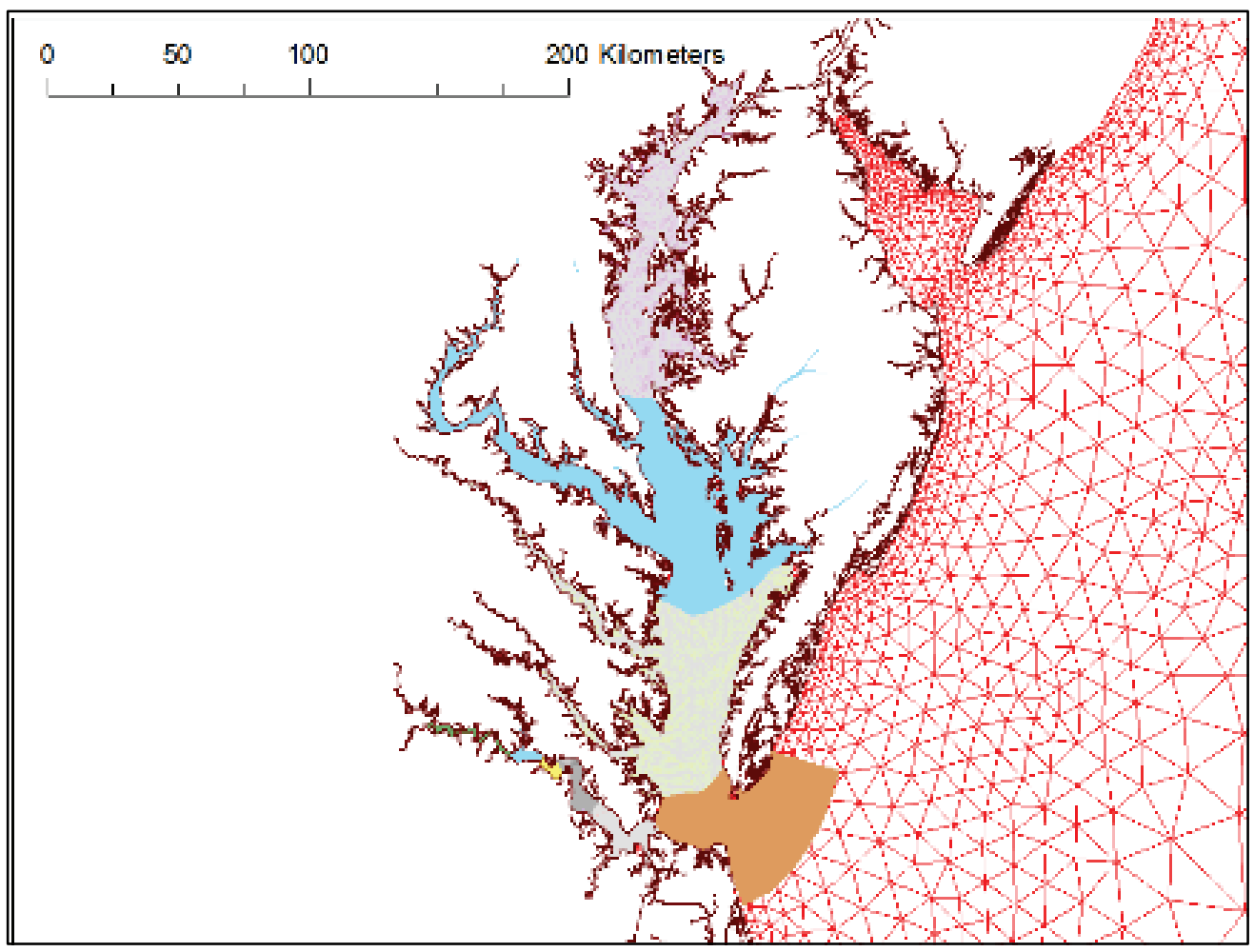


Figure 2-6. Fourteen grid blocks for the James River.

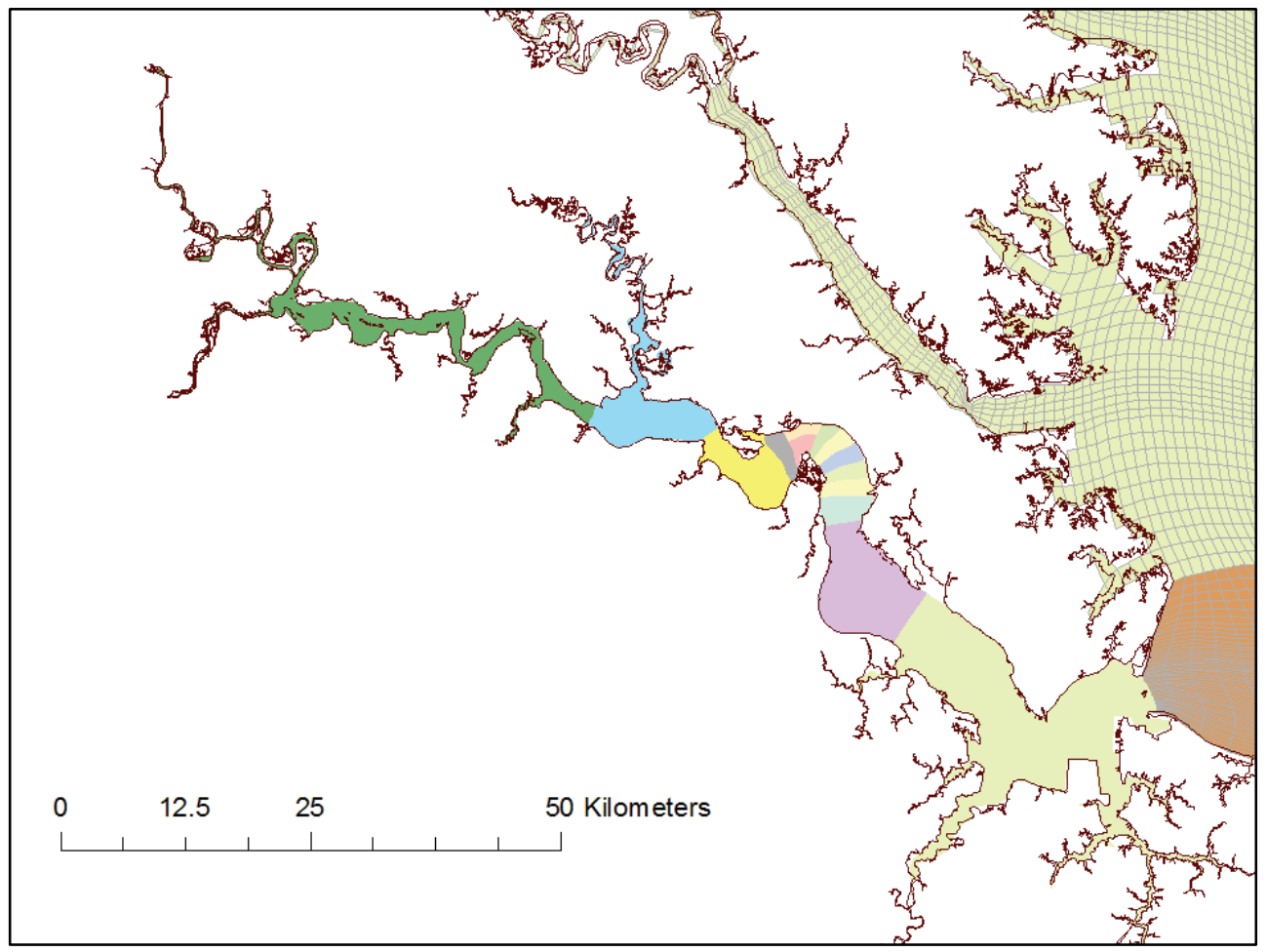

Figure 2-7. Grid block for Dancing Point - Swann Point reach of the James River (cyan). Upstream block reaches to Richmond (green). Also shown is a downstream block (gray).

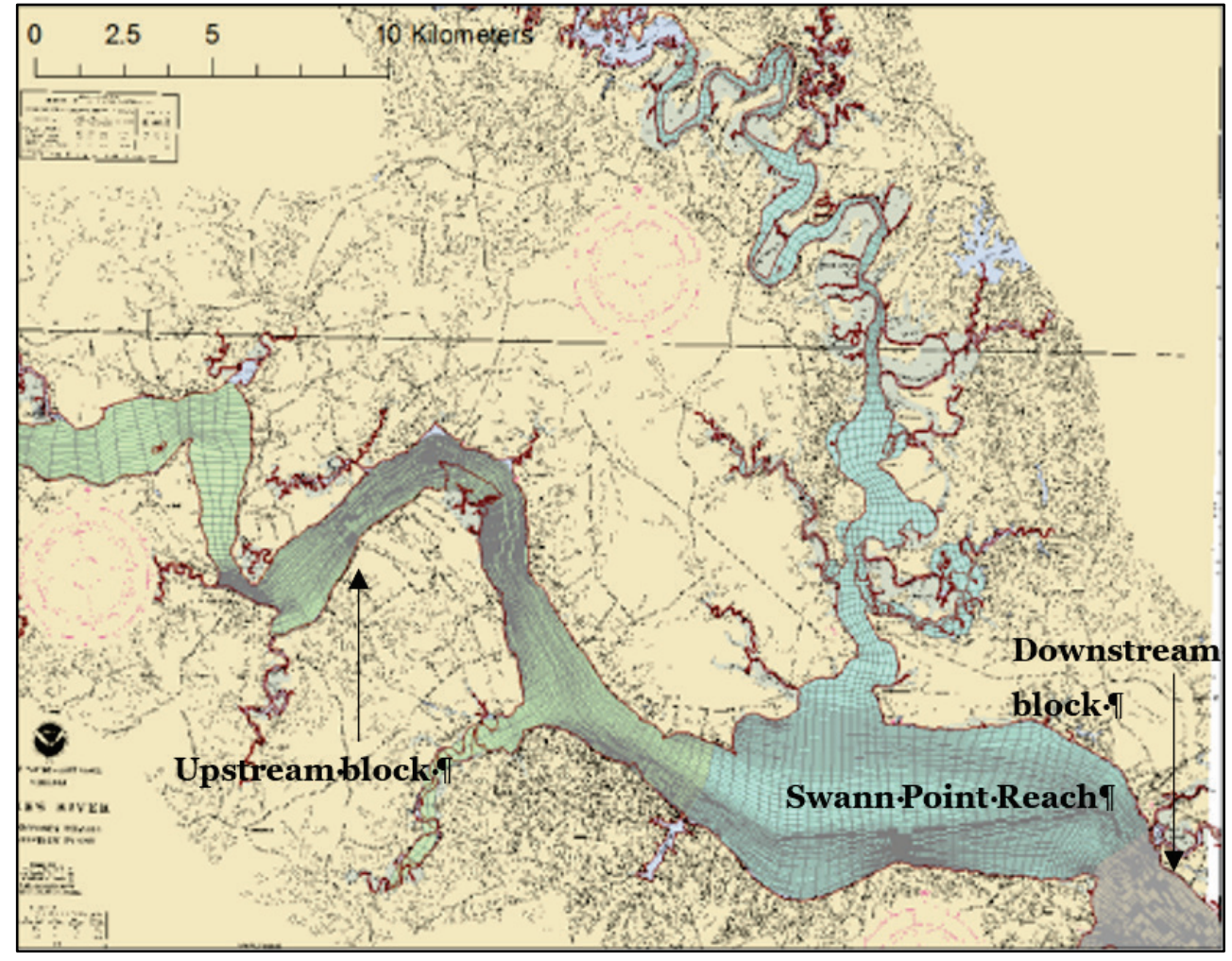


Figure 2-8. Grids following navigation channel for Dancing Point-Swann Point reach.

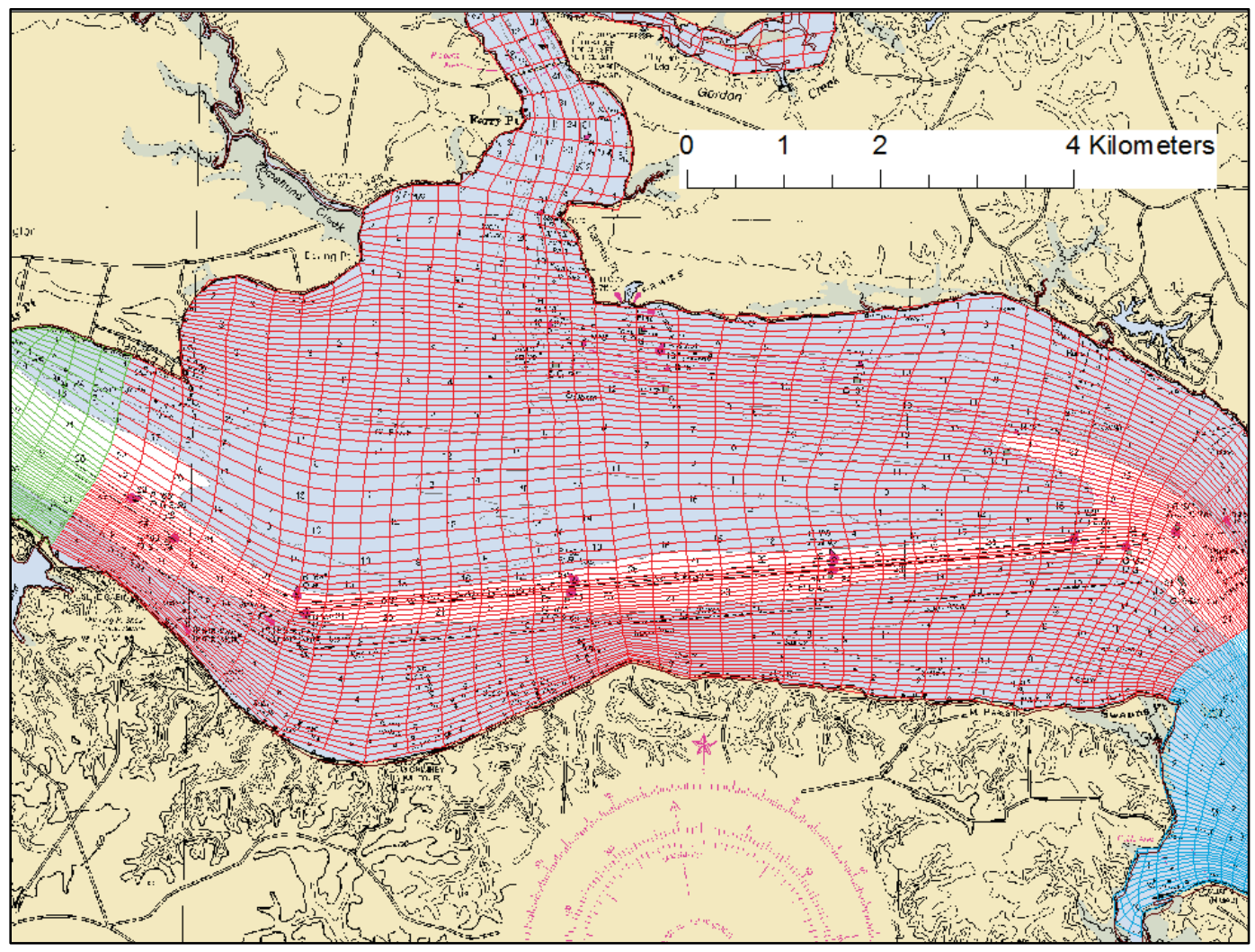

Figure 2-9. Tide gage locations for James River.

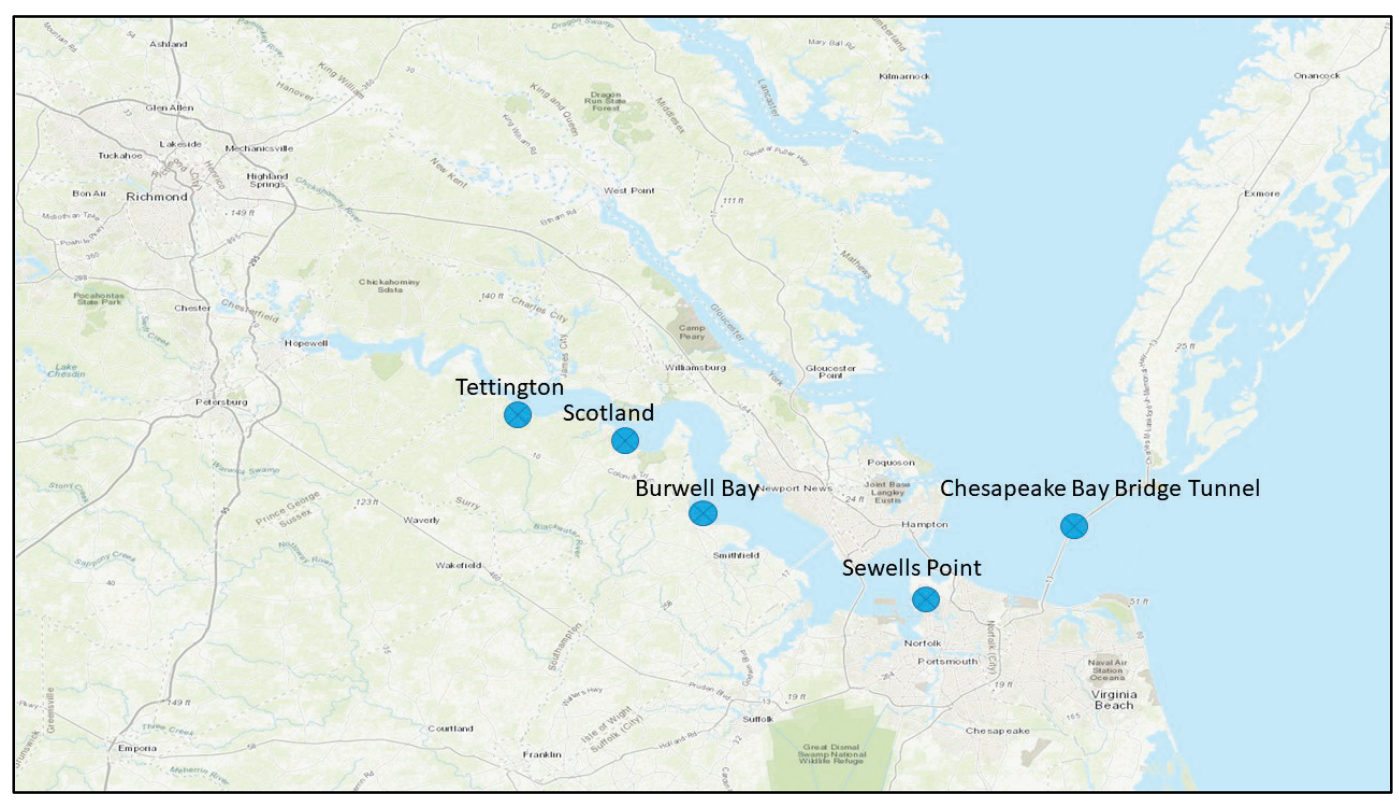


Figure 2-10. Selected Chesapeake Bay Program long-term monitoring stations for the James River and adjoining Chesapeake Bay.

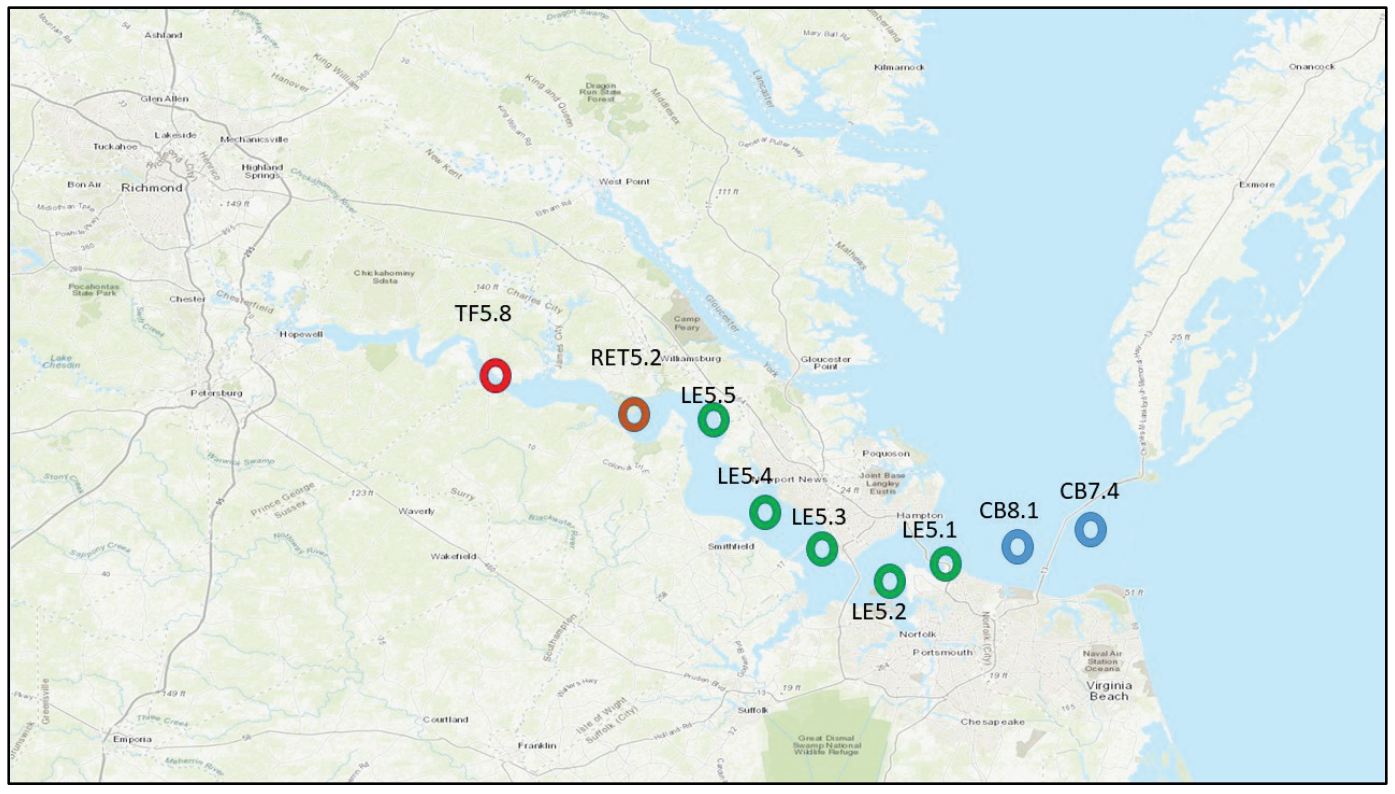

\subsection{Hydrology and meteorology}

Figure 2-11 shows the hydrological, hydrodynamic, and meteorological conditions during the first 3 months in 2010. Hydrodynamics represented by water level fluctuation indicate variations with tidal frequency.

Additionally, low-frequency water level fluctuation appears to be strongly related to meteorological conditions represented by wind speed and direction. Thus, for hydrodynamic simulation, it is imperative to have proper meteorological forcing over the model domain and astronomical tidal forcing at the boundary. Kim (2013) showed the baroclinic response of the Bay is important to provide transport mechanism of any scalar quantity such as salinity and WQ parameters. Salinity- and temperature-induced density stratification will be a key process for baroclinicity. The stratification-destrafication processes are strongly controlled by hydrologic conditions. Freshwater in the Chesapeake Bay is dominated by the Susquehanna River, followed by the Potomac River and the James River (Figure 2- 12). For the James River watershed, the James River contributes more than $90 \%$ of freshwater supply to the system (Figure 2-13). 
Figure 2-11. Hydrological, hydrodynamic, and meteorological conditions for 2010. Top panel is for fresh water discharge from James River and Appomattox River. Second panel is the water level records at Chesapeake Bay Bridge Tunnel (CBBT) tide gage location. Third and fourth panels represent wind speed and direction recorded at CBBT.
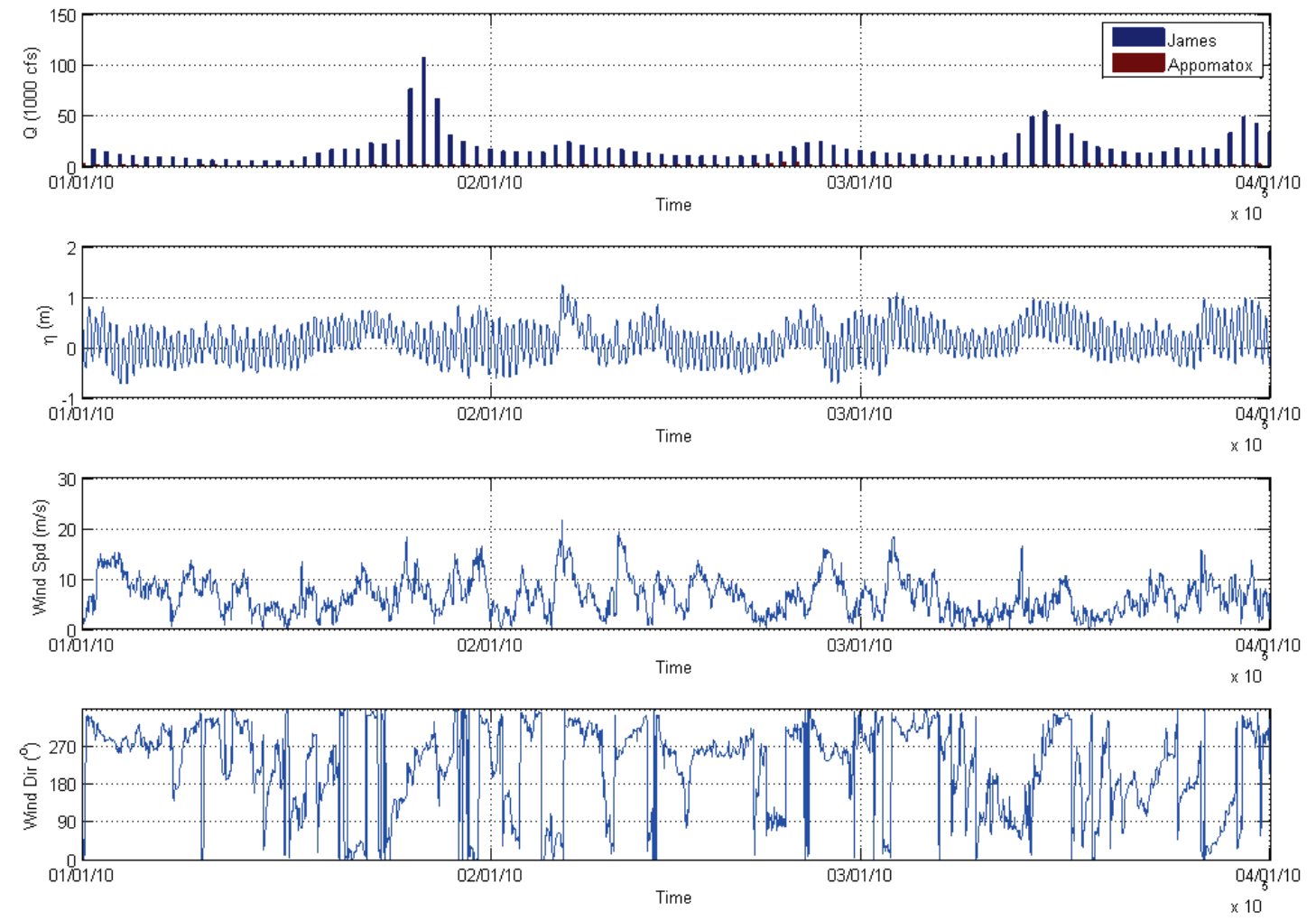
Figure 2-12. Freshwater discharge to the Chesapeake Bay (source: US Geological Survey [USGS]).

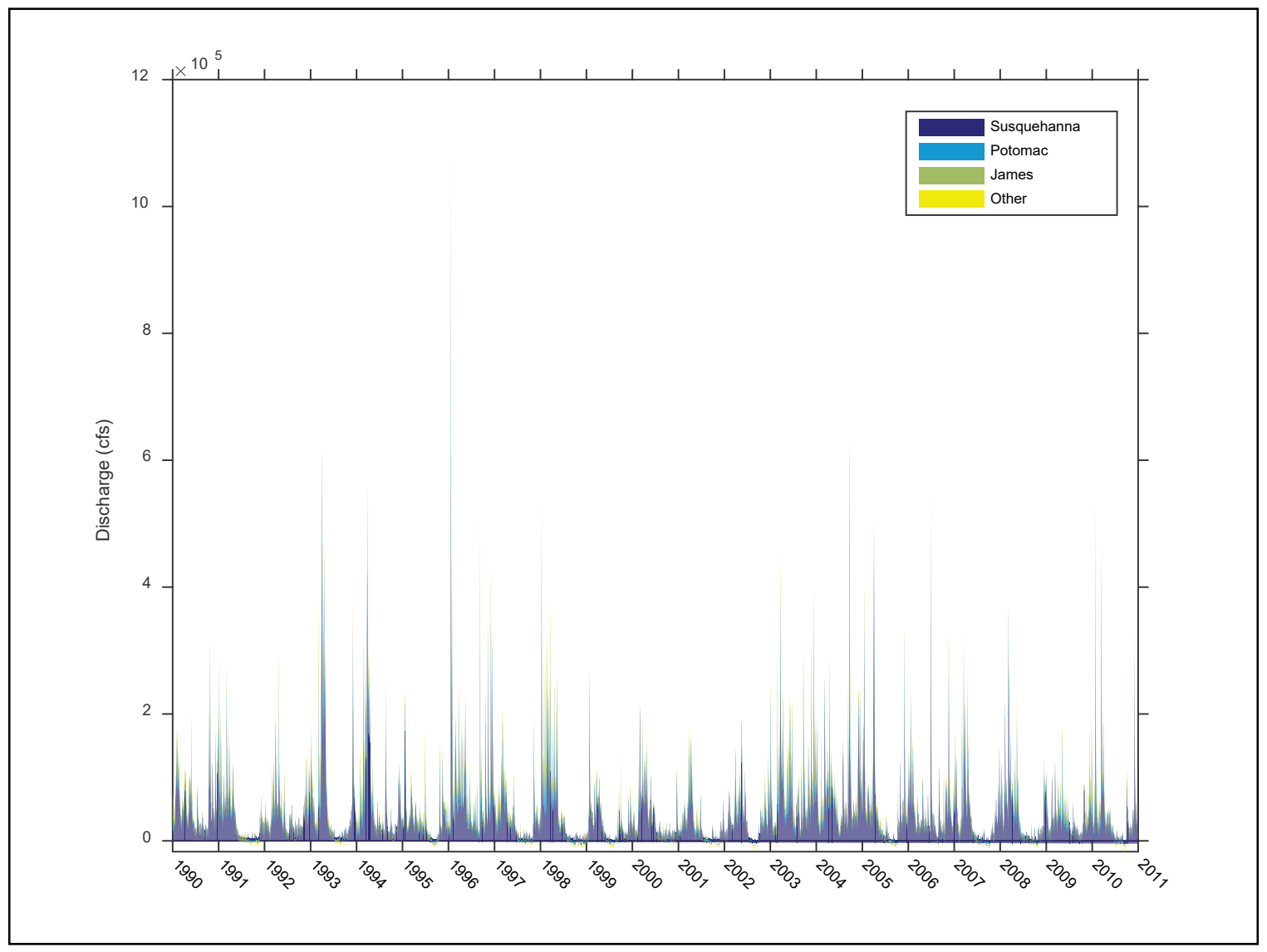

Figure 2-13. Freshwater discharges from the James River and the Appomattox River (source USGS).

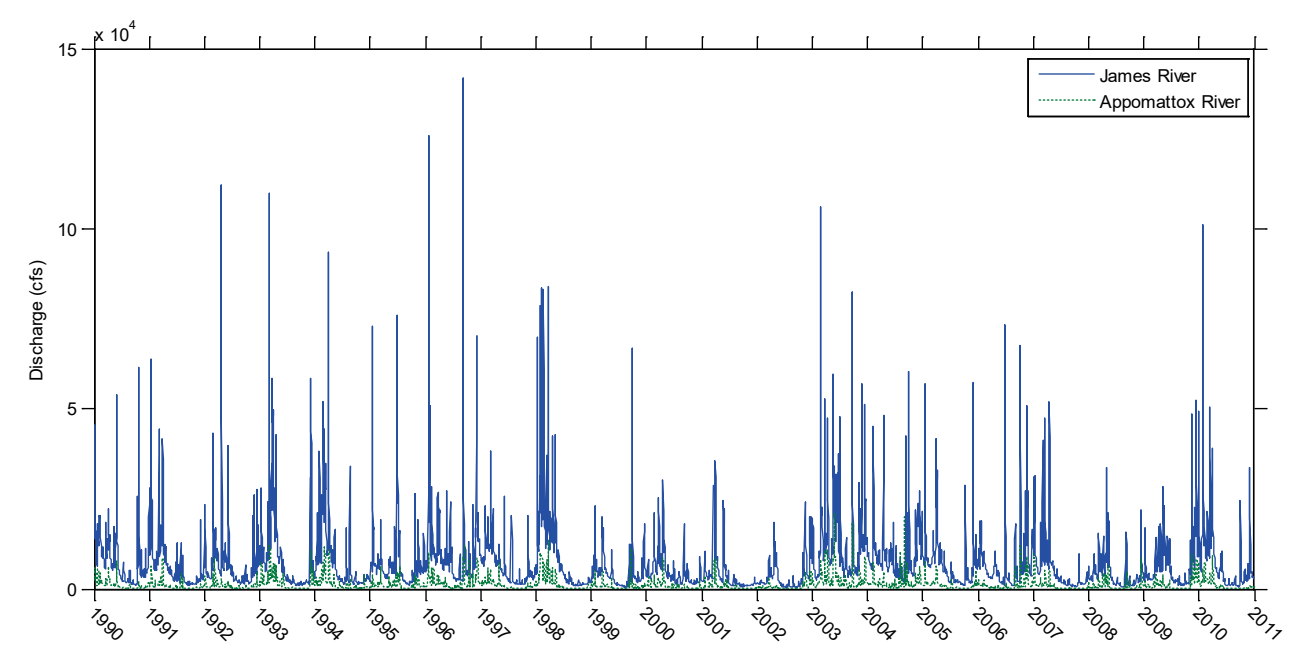




\subsection{Hydrodynamic model simulation for $\mathbf{2 0 0 0}$}

\subsubsection{Meteorology}

Year 2000 was selected for the simulation as a typical year that had enough activity to support overall sediment transport. For the meteorological conditions, reanalyzed surface conditions by Ocean Weather, Inc (OWI) were used. Figure 2-14 shows an example of the progress of a weather system. An extratropical system formed off the coast of Florida and moved northward as it developed. The responding local wind over the James River was a cyclonic change of northeast to northwest winds within a 24-hour time frame. The OWI wind provides forcing for both the ADCIRC and GSMB $\mathrm{CH}_{3} \mathrm{D}$ models.

Figure 2-14. Progress of an extratropical low-pressure system during a 1-day event in January 2000.

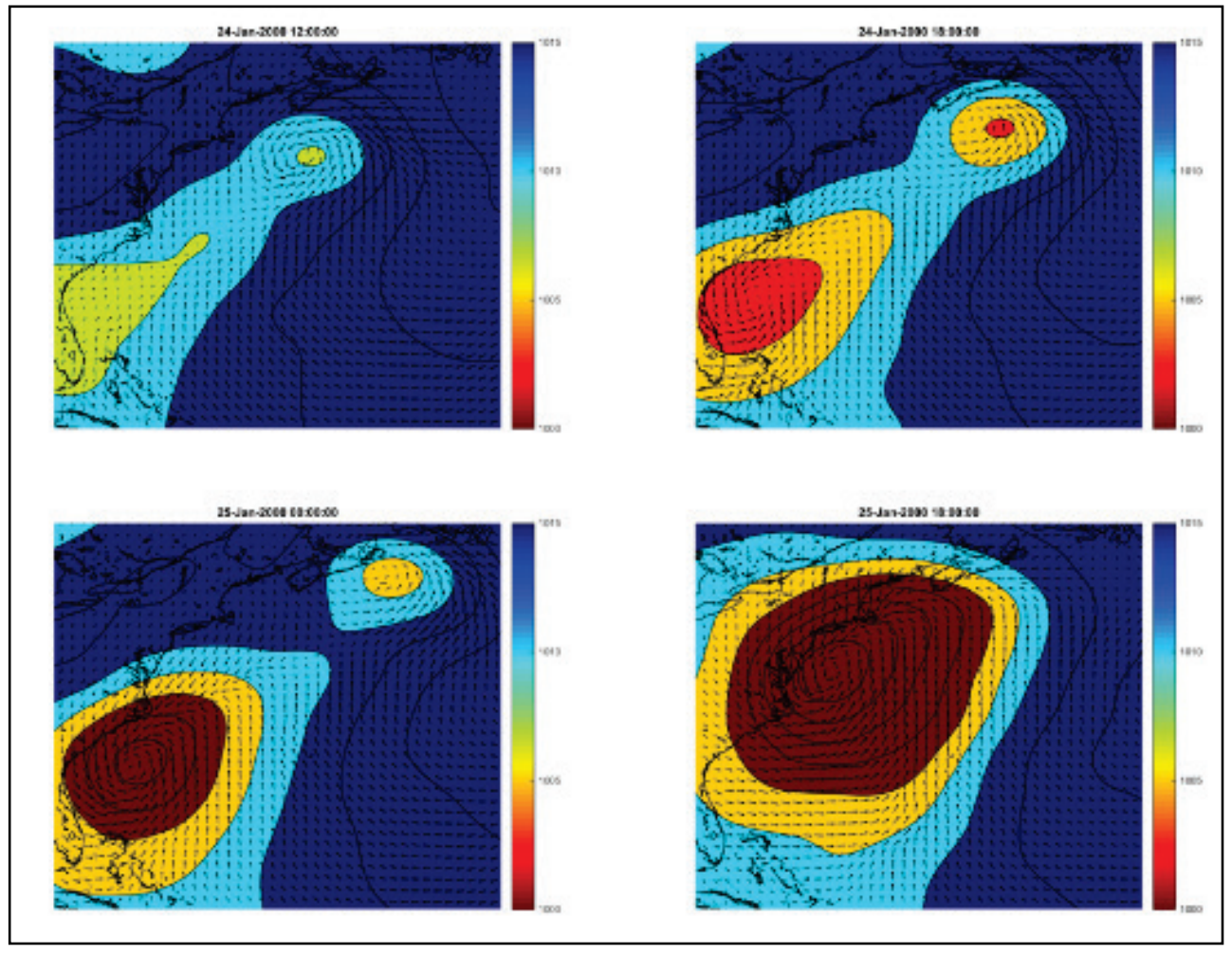

\subsubsection{Hydrology}

Year 2000 is considered a dry-to-normal year in terms of hydrological forcing (Figure 2-12). Figure 2-15 shows the discharge rates of the James River over a 1-year time period in 2000. Three moderate hydrological events were repeated with a month interval between February and April with discharge rates of 25,000 - 40,000 cfs. 
Figure 2-15. Freshwater discharge rate from the James River in 2000 (source: USGS).

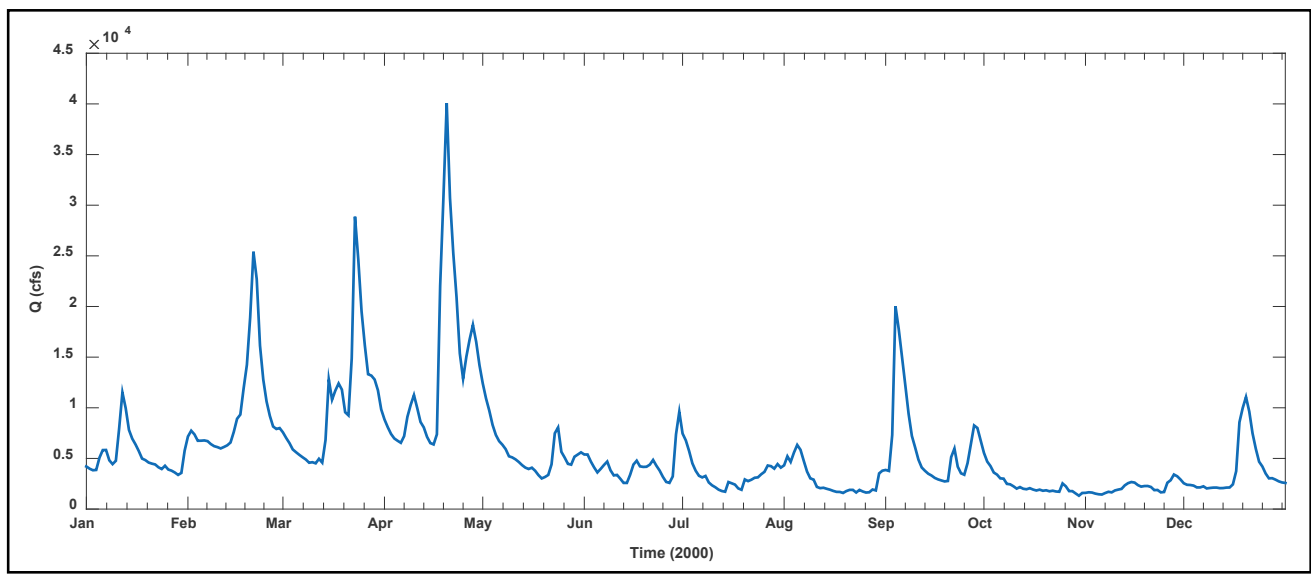

\subsubsection{Water levels}

The modeled water levels at Sewells Point show reasonable phaseamplitude response to the observed values. Dominant semi-diurnal response is evident, and meteorological events such as 26 January 2000 were replicated by the model (Figure 2-16). The significant subtidal signals from both model and observation indicate the importance of meteorological forcing for the Bay and the James River.

Figure 2-16. Water levels at Sewells Point. Red plus sign represents the observation from the National Oceanic and Atmospheric Administration

(NOAA) tide gage while the blue line represents the simulation.

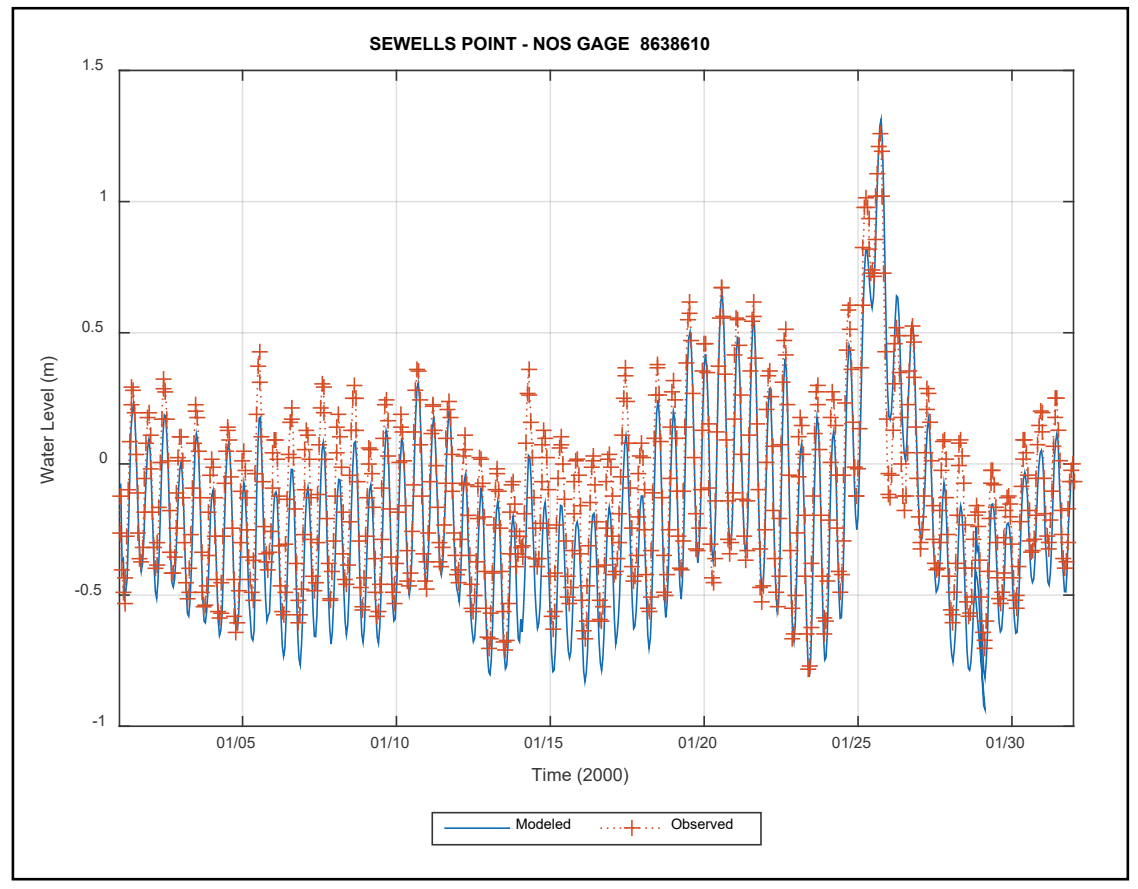


NOAA published harmonic constituents for the tide gage locations along the James River (http://tidesandcurrents.noaa.gov/stations.html?type=Harmonic+Constituents). Table 2-1 shows the top seven harmonic constituents at the CBBT located at the entrance of the Chesapeake Bay. This table indicates M2 dominates the tidal signal. All seven tidal signals were used in this modeling effort.

Table 2-1. Top seven harmonic constituents at CBBT (NOAA Gage 8638863). Data source http://tidesandcurrents.noaa.gov/harcon.html? unit=0\&timezone $=0 \& \mathrm{id}=8638863 \&$ name $=$ Chesapeake $+B$ ay+Bridge + Tunnel\&state $=\mathrm{VA}$.

\begin{tabular}{|l|l|l|l|}
\hline Name & Amplitude & Phase & Description \\
\hline M2 & 0.380 & 21.0 & Principal lunar semidiurnal constituent \\
\hline N2 & 0.090 & 1.4 & Larger lunar elliptic semidiurnal constituent \\
\hline S2 & 0.069 & 45.8 & Principal solar semidiurnal constituent \\
\hline K1 & 0.058 & 184.9 & Lunar diurnal constituent \\
\hline SA & 0.055 & 152.0 & Solar annual constituent \\
\hline O1 & 0.045 & 208.9 & Lunar diurnal constituent \\
\hline SSA & 0.042 & 34.0 & Solar semiannual constituent \\
\hline
\end{tabular}

The period of M2 is approximately 12 hours and 25.2 minutes, exactly half a tidal lunar day. HAMELS (Harmonic Analysis, Method of Least Squares: http://web.vims.edu/physical/research/TCTutorial/tideanalysis.htm) was applied to estimate amplitude and phase relations along the James River for the 2000 simulated data. To see the tide propagation, both NOAA M2 harmonic constituents and the M2 constituents from the simulation were aligned at CBBT. Five stations were selected (Figure 2-9) along the James River starting from CBBT (o km)-Sewells Point (20 km), Burwell Bay (50 km), Scotland $(8 \mathrm{om})$, and Tettington $(95 \mathrm{~km})$. Over the $95 \mathrm{~km}$ reach, M2 amplitude decreases from 0.38 to $0.26 \mathrm{~m}$. Tettington shows approximately 4 hours, 40 minutes lag compared to CBBT. Figure 2-17 shows the amplitude and phase relations of the five stations from the NOAA publication and the simulation from HAMELS analysis. The propagation characteristics appear to be reasonably represented. The smoother amplitude change in simulation indicates the possibility that the model depths are exaggerated for the portion between CBBT and Sewells Point. 
Figure 2-17. M2 tide phase and amplitude along the James River. HAMELS was used for 2000 simulation data and compared with NOAA tide tables.

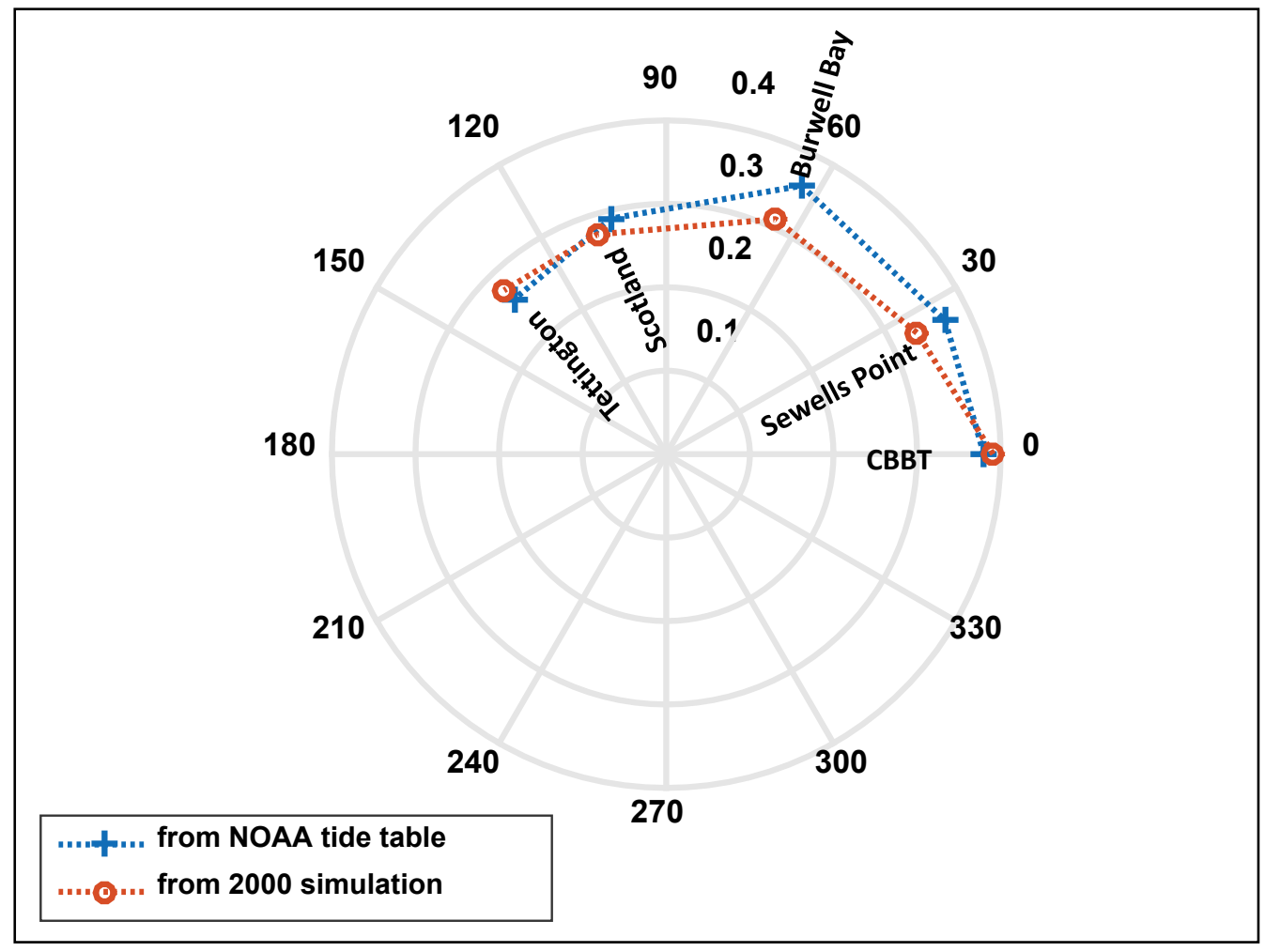

\subsubsection{Currents}

The drogue surveys for Dancing Point - Swann Point Channel were reported by Holton et al. (2002). Figure 2-18 shows the drogue data provided by the USACE Norfolk District (NAO) for 18 October 2000 2009 November 2000. In general, the drogue lines trace the contour lines, especially for ebb flows. The report also describes flood characteristics based on changing phases of tide. Ebb flows were characterized by the flows along the main navigation channel and adjacent shoals and the flows from Chickahominy River ebbing and bending toward the east, downstream of the James River. For the flood flows, the drogue lines also defined distinct behavior represented by two converging flows between Dancing Point and Swann Point-a flow following the main channel and a flow from northern shoal converging toward upstream of the flow. The average ebb surface currents from the simulation for 18 October 2000 clearly shows the ebbing flows from Chickahominy River bending toward downstream, making nearly parallel flows to the main channel flow (Figure 2-19). The average flood flows following the ebb phase indicates the possible converging flow from the northern shoal past Dancing Point (Figure 2-20). The reported maximum currents from the drogue surveys 
are approximately $80 \mathrm{~cm} / \mathrm{s}(2.4 \mathrm{ft} / \mathrm{s})$. The simulation shows slightly higher values of approximately $100 \mathrm{~cm} / \mathrm{s}$, but the quantitative comparison of Eulerian currents from the model simulation with Lagrangian currents from the drogue surveys are difficult because it is a different frame of reference. Also considering a typical tidal excursion length of $15-16 \mathrm{~km}$ from the model appears to be reasonable.

Figure 2-18. Drogue survey data. Solid blue line represents flood phase while red dotted lines represent ebb phase. The data covers 28 October 2000 to 09 November 2000.

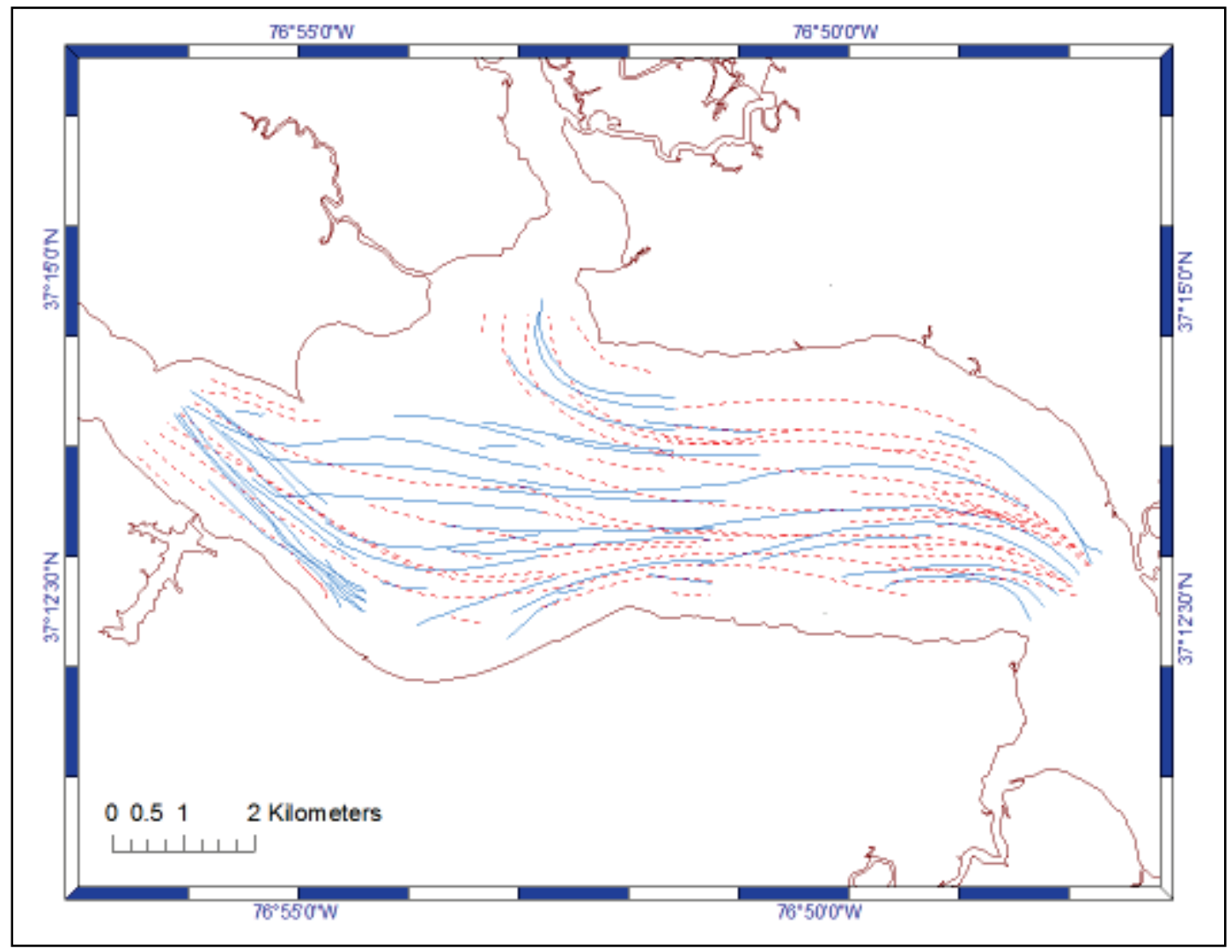


Figure 2-19. Average surface currents during ebb in 18 October 2000 from simulation.

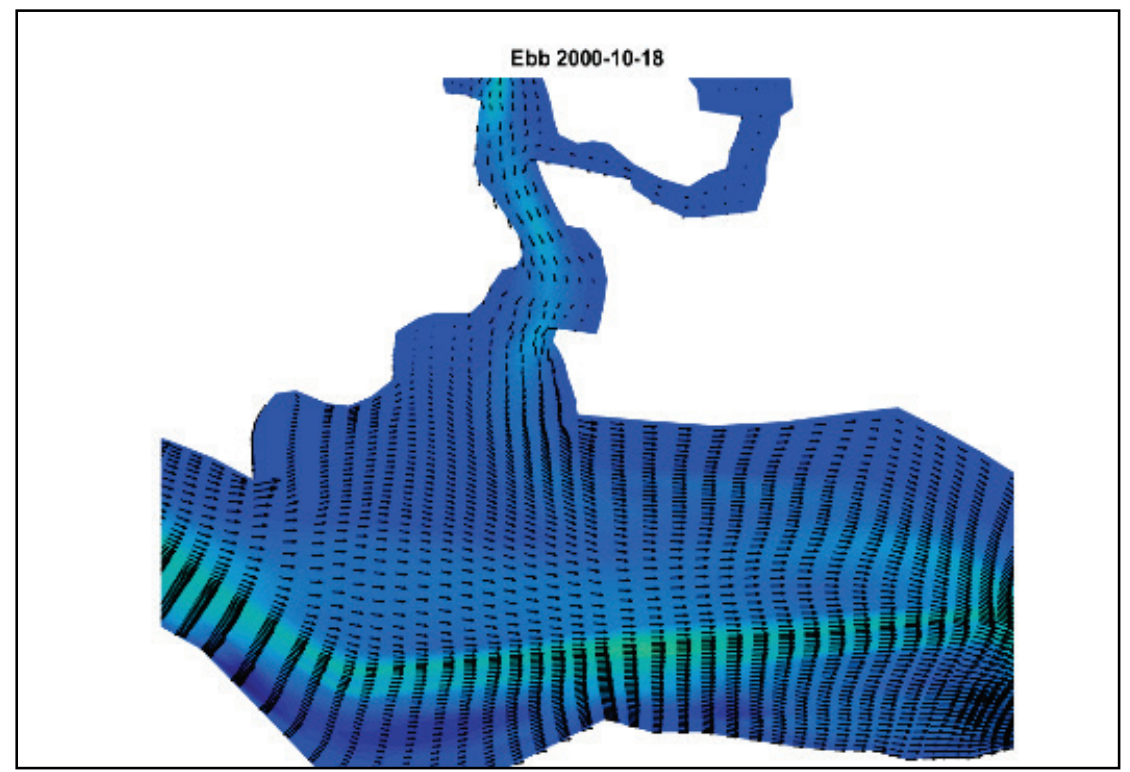

Figure 2-20. Average surface currents during flood in 18 October 2000 from simulation.

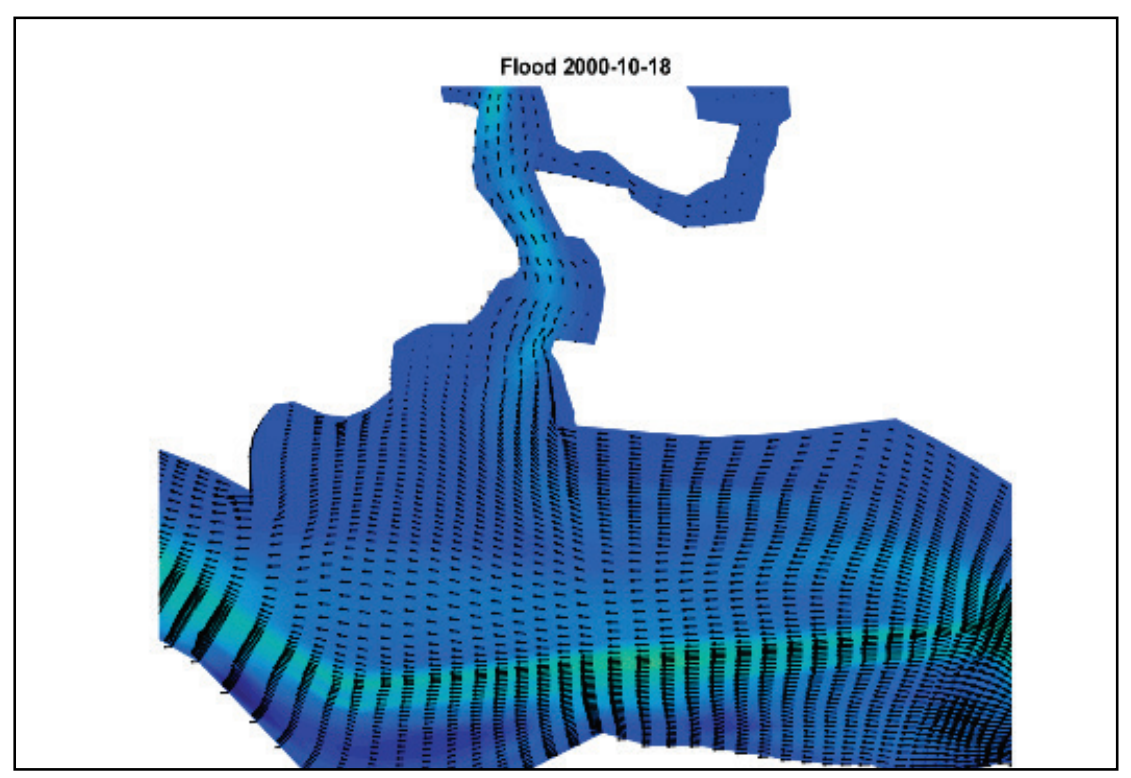

\subsubsection{Salinity}

Comparison of modeled and observed surface and bottom salinity at selected CBP stations along the James River indicate reasonable spatial distribution over the year. Salinity at the entrance of the Bay (CB7.4) hovers at approximately $30 \mathrm{ppt}$, and the values decrease to near zero at the upstream site RET5.2 (Figure 2-21). 
Figure 2-21. Time series of surface (red) and bottom (blue) salinity at selected Chesapeake Bay Program (CBP) long-term monitoring stations along the James River. Lines represent simulation, and the circles are from CBP monitoring data.
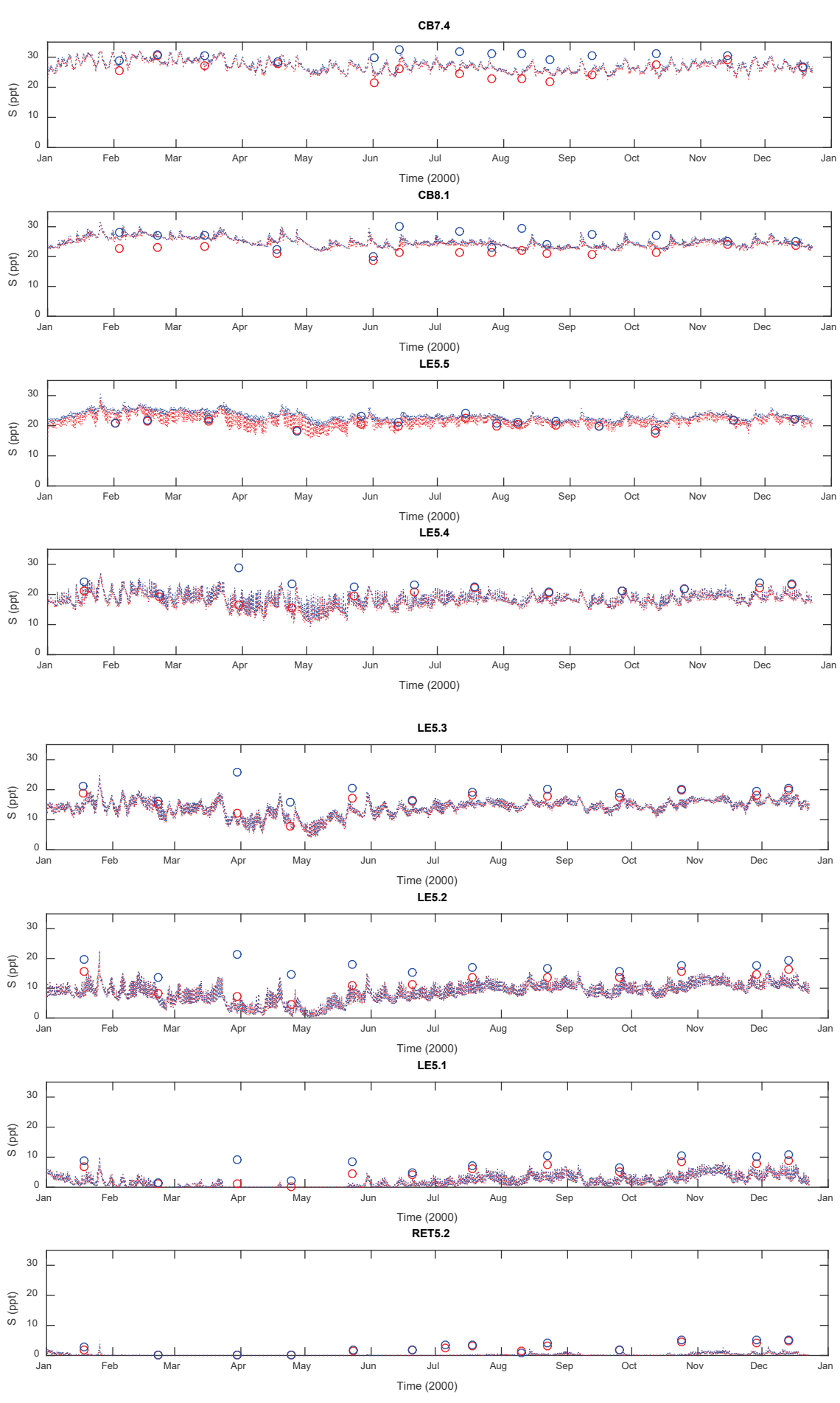


\subsection{Summary and conclusion}

Based on the GSMB Transport Modeling System, a MB (3D) finite difference model was constructed for the James River and the adjacent Chesapeake Bay. The project area Dancing Point - Swann Point and adjoining Chickahominy River was represented by a high-resolution grid to model the navigation channel as well as the shoals.

The hydrological was driven from USGS gage data from James River at Richmond, Appomatox River, and Chickahominey River whereas the meteorological forcing was defined by OWI reanalyzed surface conditions. Water levels at the boundary were extracted from the existing 6oK-node East Coast ADCIRC model. The temperature and salinity at the open boundary were set by values from the Environmental Protection Agency Chesapeake Bay Program long-term monitoring stations at the Chesapeake Bay entrance.

The hydrodynamic model was calibrated for both water levels and salinity. The tidal current behavior was analyzed and qualitatively compared to NAO drogue survey data. The model simulated 3D currents drive the PTM results. The model results also form the basis for development of the Eulerian sediment transport model. 


\section{Cohesive Sediment Transport Processes}

Site-specific data for erosion of sediments provides parameterization for numerical modeling of dredged sediment fate in the James River. Background information and a site description are provided in Chapter 1. One objective of this study is to predict the fate of dredged material. Present sedimentation in the navigation channel is predominantly finegrained, cohesive sediments. Similarly, native sediments outside the channel are also fine-grained. To predict the stability of dredged sediment mounds and the fate of sediment eroded from these mounds requires application of a numerical cohesive sediment transport model (Chapter 6). The cohesive sediment transport model requires the parameterization of the first-order transport processes of erosion and settling. This chapter describes field and laboratory experiments conducted to define the cohesive sediment transport erosion processes of James River dredged sediment mounds and analysis of these data to parameterize cohesive sediment transport in the numerical sediment transport model.

\subsection{Cohesive sediment transport processes}

Transport of dredged sediment in the James River is dominated by cohesive transport processes. Non-cohesive sediment (sand and gravel) erosion and settling can be generally estimated from grain size distribution and mineral density. Cohesive sediment transport processes are dominated by other factors. Cohesive sediments are generally a mixture of sand, silt, and clay-sized particles.

A general characteristic of cohesive sediment is sediment for which the erosion rate cannot be estimated by standard sand/gravel transport methods. In these cases, cohesive forces are equivalent to or are greater than the gravitational forces that dominate sand transport. Cohesive sediment erosion characteristics are highly dependent upon factors such as particle size distribution, particle coatings, fine sediment mineralogy, organic content, bulk density, gas content, pore-water chemistry, and biological activity. The erosion rate and critical shear stress for initiation of erosion can vary significantly with small changes in only one of these inter-dependent parameters. It has been well demonstrated that critical stress and erosion rates for cohesive sediment can vary over several orders of magnitude for sediments with only slightly differing properties. Therefore, the influence of cohesion on sediment processes is significant. 
Qualitatively, it is understood which properties most significantly influence erosion. However, there are no quantitative methods available to determine erosion rates from cohesive sediment properties. Therefore, due to the sensitivity and wide range of influencing parameters, erosion characteristics of cohesive sediments are determined by site-specific analysis of erosion with erosion flumes.

Several flumes are available to parameterize site-specific cohesive sediment erosion algorithms. Most of these devices operate over a range of low shear stress $(<2 \mathrm{~Pa})$ and are consequently capable of measuring only surface sediment erosion. Sedflume is an erosion device with the capability to impose bed stresses in the range of 0.1 to $12 \mathrm{~Pa}$ and measures erosion rates from sediment cores taken from the field for in situ or stratified bed conditions or prepared in the laboratory for assessing disturbed sediments such as dredged material. Sedflume is designed to quantify erosion rates for surface and sub-surface sediments. These measurements permit description of the vertical variation of erosion rate within the bed. Note that even if sediments are well mixed, cohesive sediment bed erosion will change with depth due to the influence of consolidation, or bed density, on erosion rate. Erosion rate can vary by several orders of magnitude between surficial sediments and sediment buried less than $30 \mathrm{~cm}$ below the surface. Sedflume was selected to quantify the erosion rate and erosion rate variation with depth and thus the density for this study.

\subsection{Methods}

This section describes the laboratory experiments, sampling and experimental methods, and data analysis methods used in determining cohesive sediment erosion rates for the James River dredged material. Background and technical information about the experimental device are presented first, followed by a description of how this device was utilized for laboratory experiments to meet the study objectives.

\subsubsection{Sedflume}

Sedflume is a field- or laboratory-deployable flume for quantifying cohesive sediment erosion. The USACE-developed Sedflume is a derivative of the flume developed by researchers at the University of California at Santa Barbara (McNeil et al. 1996). The flume includes an $80 \mathrm{~cm}$ long inlet section (Figure 3-1) with cross-sectional area of $2 \times 10 \mathrm{~cm}$ for uniform, fully developed, smooth-turbulent flow. The inlet section is followed by a 
$15 \mathrm{~cm}$ long test section with a $10 \times 15 \mathrm{~cm}$ open bottom (the open bottom can accept cores with rectangular cross-section $(10 \times 15 \mathrm{~cm})$ or circular cross section (10 cm diameter) ). The coring tubes and flume test section, inlet section, and exit sections are constructed of clear polycarbonate materials to permit observation of sediment-water interactions during the course of erosion experiments. The flume includes a port over the test section to provide access to the core surface for physical sampling. The flume accepts sediment cores up to $80 \mathrm{~cm}$ in length.

Figure 3-1. Sedflume erosion flume (lower right). Core inserted into test section (upper left). Core surface flush with bottom of flow channel (upper right). Table of shear stress associated with channel flow rates (lower left).

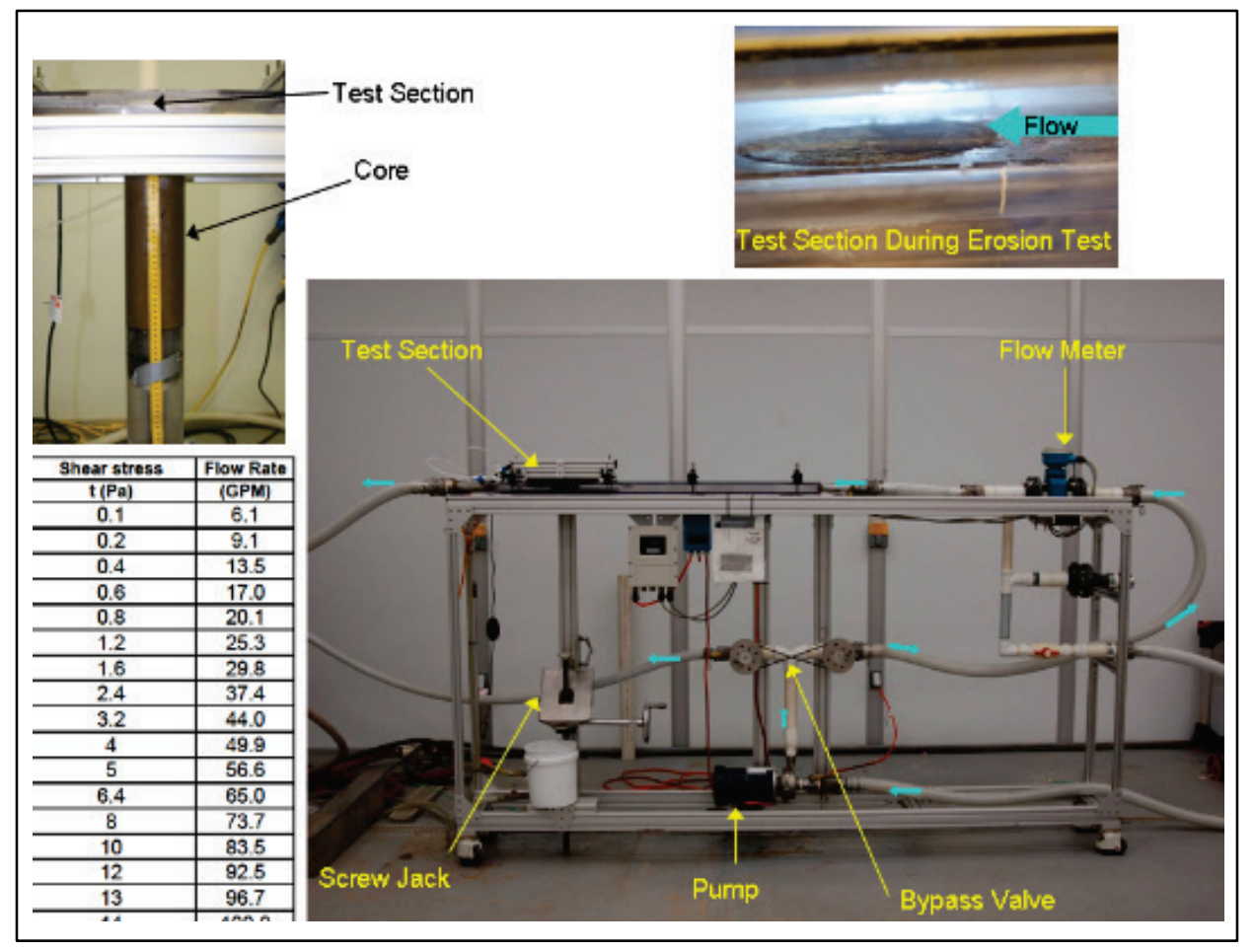

\subsubsection{Erosion experiments}

Prior to conducting an erosion experiment, descriptions of the core are recorded, including length, condition of the core, and any visual evidence of layering. Cores are inserted into the testing section of Sedflume, and a screw jack is used to advance the plunger such that the core surface becomes flush with the bottom wall of the flume. Flow is directed over the sample by diverting flow from a $5.5 \mathrm{hp}$ trash pump, through a $5 \mathrm{~cm}$ inner diameter hose, into the flume. The flow through the flume produces shear stress on the surface of the core. Numerical, experimental, and analytical analyses have been previously performed to relate flow rate to bottom shear stress. 
Erosion of the surface sediment is initiated as the shear stress is increased beyond the critical stress for erosion, $\tau_{\mathrm{cr}}$. As sediment is eroded from the core surface, the operator advances the screw jack to maintain the sediment surface flush with the bottom wall of the erosion flume. Figure 3-1 includes a photograph of the flume, a close-up photograph of the test section, and a table of flow rate/shear stress relationships.

Erosion velocity is determined from the displacement of the core surface over the elapsed time of the experiment. Generally, erosion experiments are performed by repeating a sequence of increasing shear stresses. Approximately 1-5 $\mathrm{mm}$ of sediment are eroded during each erosion experiment at a specified shear stress, and thus the duration of each test was dependent on the rate of erosion. Generally, these erosion tests were between 0.33 and 10 minutes in duration. The sequence of shear stresses utilized is determined by first identifying the upper and lower shear stress bounds for the test sediment. Past experience has shown that the operational upper and lower erosion velocity limits for Sedflume erosion experiments are $1.7 \times 10^{-2} \mathrm{~cm} / \mathrm{s}$ and $1.7 \times 10^{-4} \mathrm{~cm} / \mathrm{s}$, respectively. To identify the shear stresses that correlate to these erosion velocity limits, an erosion sequence is conducted in the surface region (upper 1-5 cm) of each core. Once the range of operational shear stresses is determined, five equally spaced shear stresses spanning the range of operation are selected. These five shear stresses became the erosion sequence, which was repeated five times for each core. An average erosion velocity is then calculated for each shear stress. A diagram depicting this erosion test process along with an example erosion sequence is shown in Figure 3-2. The shear stress range for the James River experiments was 0.8 to 2.4 Pa, and the erosion sequence was o.8, 1.2, 1.6, 2.0, and 2.4 Pa.

Physical samples for bulk sediment property measurements were taken at approximately $3-5 \mathrm{~cm}$ intervals during erosion experiments, generally at the end of an erosion sequence. Physical samples were collected by draining the flume channel, opening the port over the test section, and extracting a sample from the sediment bed. These samples were then measured for bulk density and grain-size distribution. These properties strongly influence erosion, therefore, documenting any variation with depth is important in interpreting the erosion data. 
Figure 3-2. Diagram of sediment core erosion process. The brown arrow indicates direction of motion of the sediment into the flume as the screw jack is advanced. The blue arrow indicates flow direction of water.

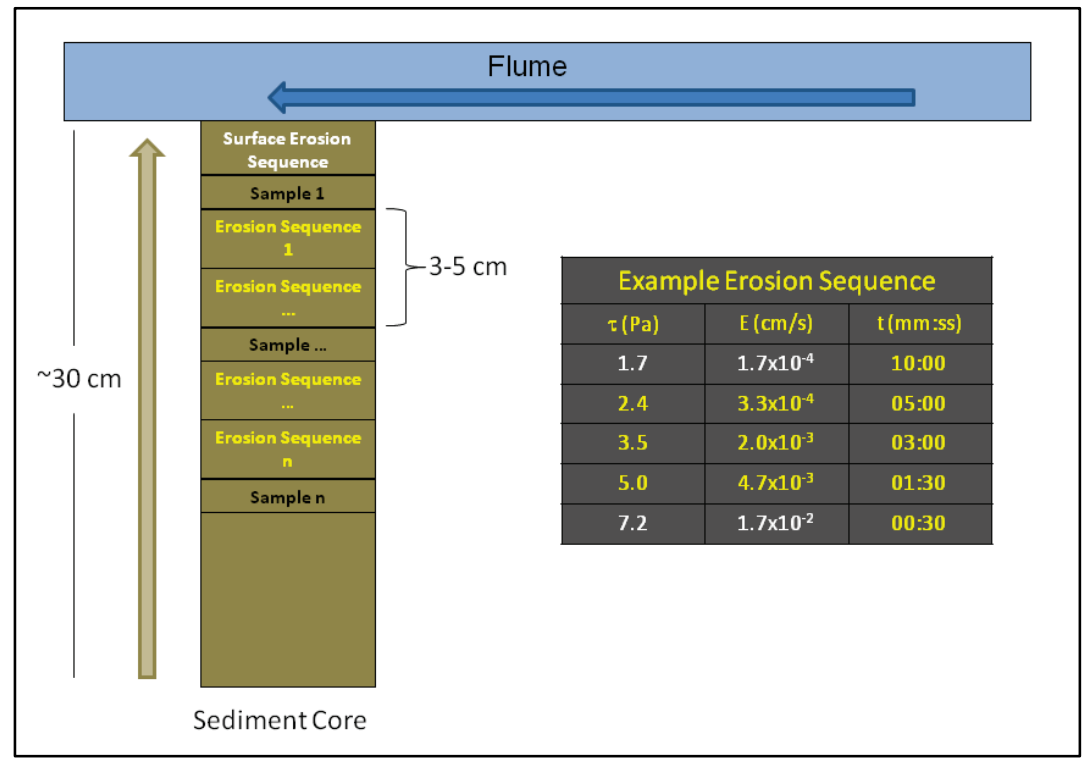

At the start of the erosion test, operational shear stress limits are identified during the surface erosion sequence (shown in white lettering in the table in Figure 3-2). These limits set the bounds and determine the spacing of shear stress intervals for the erosion sequence. An example erosion sequence is provided in the table to the right of the sediment core. The erosion sequence is repeated multiple times throughout the core with physical samples being collected every 3 to $5 \mathrm{~cm}$.

\subsubsection{Sediment bulk properties}

\subsubsection{Bulk density measurements.}

Bulk sediment density of physical samples is determined by a wet-dry weight analysis. Physical samples are extracted from the saturated core surface and placed in a pre-weighed aluminum tray. Sample weight is recorded immediately after collection and again after a minimum of 12 hours in a $50^{\circ} \mathrm{C}\left(122^{\circ} \mathrm{F}\right)$ drying oven. Wet weight of the sample was calculated by subtracting tare weight from the weight of the sample. The dry weight of the sample was calculated as the tare weight subtracted from the weight after drying. The water content, $w$, is then given by

$$
w=\left(\frac{m_{w}-m_{d}}{m_{d}}\right)
$$


where $m_{w}$ and $m_{d}$ are the wet and dry weights, respectively. A volume of saturated sediment, $\mathrm{V}\left(\mathrm{cm}^{3}\right)$, consists of both solid particles and water and can be written as

$$
V=V_{s}+V_{w}
$$

where $\mathrm{V}_{\mathrm{s}}$ is the volume of solid particles and $\mathrm{V}_{\mathrm{w}}$ is the volume of water. If the sediment particles and water have density $\rho_{\mathrm{s}}$ and $\rho_{\mathrm{w}}$, respectively, the water content of the sediment can be written as

$$
w=\frac{\rho_{w} V_{w}}{\rho_{s} V_{s}}
$$

A mass balance of the volume of sediment gives

$$
\rho V=\rho_{s} V_{s}+\rho_{w} V_{w}
$$

where $\rho$ is the bulk density $\left(\mathrm{g} / \mathrm{cm}^{3}\right)$ of the sediment sample.

Equations 3-2 through 3-4 are used to derive an explicit expression for the bulk density of the sediment sample, $\rho$ as a function of the water content, $\mathrm{w}$, and the densities of the sediment particles and water. This equation is

$$
\rho=\rho_{s}+\frac{w \rho_{\mathrm{s}}\left(\rho_{w}-\rho_{s}\right)}{\rho_{w}+w \rho_{s}}
$$

For the purpose of these calculations, $\rho_{\mathrm{s}}=2.65 \mathrm{~g} / \mathrm{cm}^{3}$ and $\rho_{\mathrm{w}}$ are calculated for measured pore water at sample temperature.

\subsubsection{X-Radiography}

Considerable variation in bed density is often found within the upper portion of the sediment bed, and consequently, high-resolution, highaccuracy methods are desired to relate erosion to bed density. Additionally, since the sediment cores are to be eroded in the Sedflume, a nondestructive method is required. Many non-destructive methods for determining sediment bed density rely on the mass attenuation of incident 
electromagnetic radiation. The relationship for mass attenuation is commonly described using the Beer-Lambert Law:

$$
I=I_{0} e^{-\mu \rho x}
$$

where

$$
\begin{aligned}
\mathrm{I} & =\text { transmitted } \mathrm{x} \text {-ray intensity } \\
\mathrm{I}_{0} & =\text { incident } \mathrm{x} \text {-ray intensity } \\
\mu & =\text { mass attenuation coefficient } \\
\rho & =\text { material density }\left(\mathrm{g} / \mathrm{cm}^{-3}\right) \\
\mathrm{x} & =\text { thickness of sample material }(\mathrm{cm}) .
\end{aligned}
$$

Equation is rearranged to solve for material density

$$
\rho=\frac{-1}{\mu x} \ln \left(\frac{I_{o}}{I}\right)
$$

The parameters $I, I o$, and $x$ are experimentally measured, and the mass attenuation coefficient is determined through a series of calibrations. To non-destructively obtain sediment densities, a $160 \mathrm{kV}$ Gulmay x-ray system with Comet tube head (MXR-16o/22), collimated to a beam width of approximately $1 \mathrm{~mm}$ at the tube window and shielded to reduce lowenergy photon energy to the detector, was used to scan the cores.

X-ray transmission was detected by an Amptek XR-10oCR multichannel detector coupled with an Amptek PX4 digital pulse processor and multichannel analyzer. The x-ray detector was collimated and filtered with an arrangement of brass and tungsten collimators with diameter openings ranging from $3 \mathrm{~mm}$ to $0.025 \mathrm{~mm}$. The multichannel analyzer permits digital filtering of the transmission to eliminate photon counts beneath the $100 \mathrm{keV}$ threshold, resulting in a near-constant mass attenuation coefficient. Only counts in the $100-140 \mathrm{keV}$ range are utilized to calculate the density of the sediment.

To perform a density scan, the core was placed inside a lead shielded cabinet and secured in a vertical position. The x-ray tube and detector were then stepped along the core with electronic motors to accomplish a full length density scan. The upper $28 \mathrm{~cm}$ of the core was scanned at $1 \mathrm{~mm}$ resolution. Because most consolidation was expected to occur in the upper 
regions of the core, resolution was reduced to $2 \mathrm{~mm}$ below $28 \mathrm{~cm}$. To ensure that density variation was within $1 \%$ of the expected Gaussian variation at $95 \%$ confidence, each scanning position was held for a duration of $20 \mathrm{sec}$. This allowed for over 300,000 counts in the 100 to 140 $\mathrm{keV}$ range to be detected per step-down core.

Calibrations of the instrument ( $\mathrm{I}_{\mathrm{o}}$ scans) were performed periodically throughout the density scan. These calibrations involved repositioning the $\mathrm{x}$-ray tube and detector to a location that allowed the $\mathrm{x}$-rays to pass through a section of the core that was filled only with distilled water. These calibrations were then applied to the data to account for the effects of the polycarbonate wall, water, and any change in temperature that may occur during the duration of the density scan.

Particle-Size Distribution. Particle size was evaluated using two different methods. In the first method, a Malvern Mastersizer 2000 laser particlesizer was used to measure the particle-size distributions. The Malvern measures particle size over the range 0.4 to $900 \mu \mathrm{m}$. Sediment samples were homogenized, and six sub-samples of 1 to $2 \mathrm{~g}$ each were extracted. Particle size distributions were measured by first removing and sieving particles larger than $850 \mu \mathrm{m}$. The passing portion of the sample was added to a small volume of water (approximately $150 \mathrm{~mL}$ ) and sonicated by deflocculating it overnight in a solution of sodium metaphosphate $(40 \mathrm{~g} / \mathrm{L})$ using a high-powered laboratory sonicator to disperse the sediment. The dispersed solution was placed in the particle sizer fluid module. The sample is pumped and recirculated through the optical module. The optical module includes a spatial filter assembly containing a laser diode and laser beam collimator. The diffraction detector assembly contains a custom photo-detector array that is used for the measurement of light scattering by the suspended particles. The distribution of grain sizes and median grain sizes is derived from this light scattering measurement. The size distribution of fines passing the $850 \mu \mathrm{m}$ sieve is scaled to account for the sediment mass retained on the sieve. Organic material was not oxidized before grain size analysis was performed; therefore, grain size distributions include organic material. The grain size distribution for the six sub-samples tested is provided in Figure 3-3. It can be seen that results are consistent between samples, indicating that the slurry was well mixed. 
Figure 3-3. Grain size data for samples extracted from original slurry.

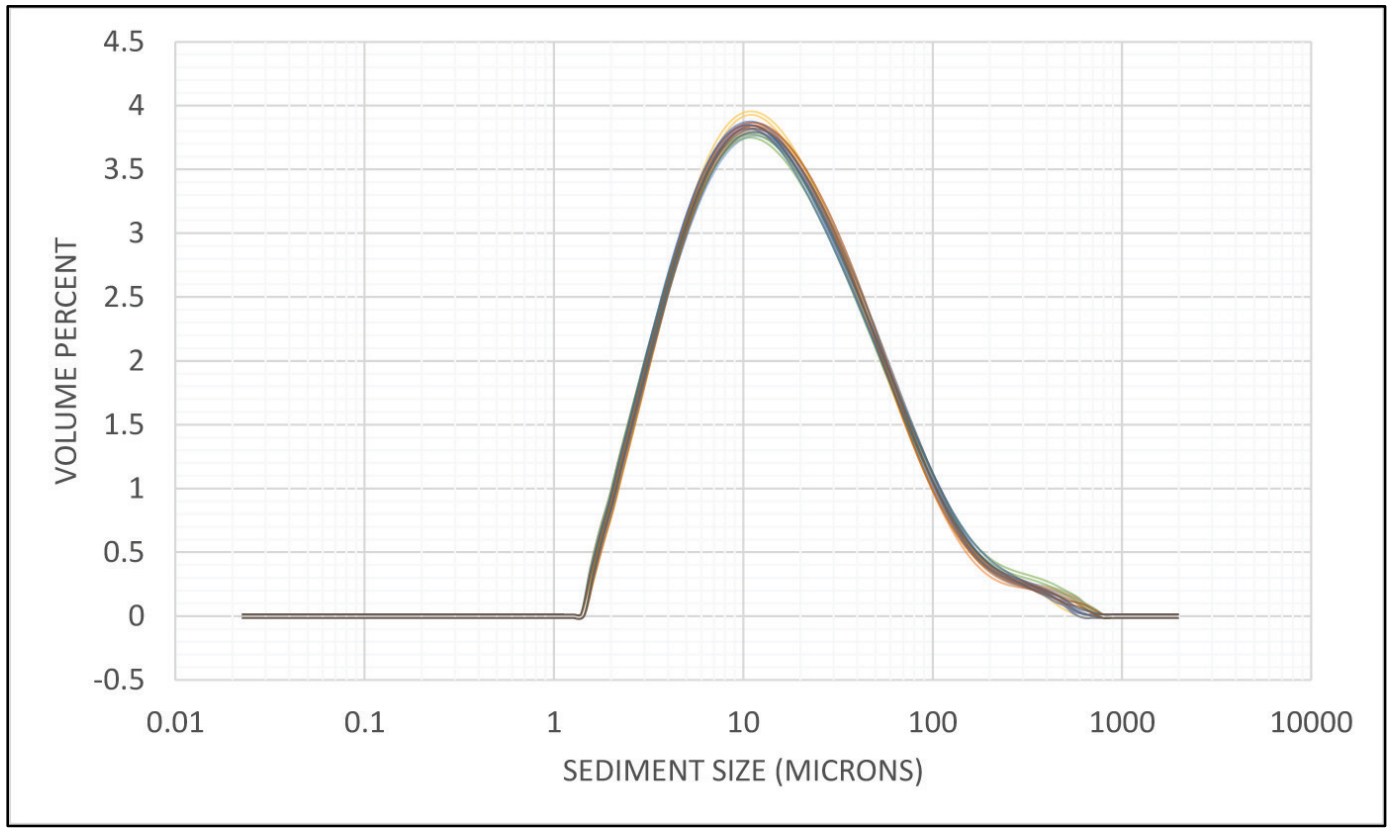

The second method was similar to the first, using a Beckman Coulter LS 100Q particle size analyzer, which measures particles in the 0.4 to $948 \mu \mathrm{m}$ range. Three buckets of sediment were homogenized using a Lighting ${ }^{\circledR}$ mixer, and a subsample (approximately 8-10 g, wet) taken for analysis. The subsample was slurried with approximately $50 \mathrm{ml}$ water then sonicated for 2 minutes using a 600-watt, $20 \mathrm{kHz}$ ultrasonic processor at 17 amps. The entire sample was rinsed into the instrument fluid module and water added to obtain an obscuration level between $8 \%$ and $12 \%$. The instrument setup of the Coulter is similar to that of the Malvern, using laser light with $750 \mathrm{~nm}$ wavelength. The laser beam passes through the sample cell containing suspended particles that scatter the light depending on their size. Fourier optics collect the diffracted light and focus it onto a set of 126 detectors. The sample is recirculated through the instrument, allowing two separate measurements of the sample for 60 sec each. The Fraunhofer theory of light scattering was used to calculate particle size from the detector measurements. The averaged results from both methods are given in Table 3-1 below. 
Table 3-1. Grain size distribution results.

\begin{tabular}{|l|l|l|}
\hline & Method 1 & Method 2 \\
\hline \% Sand & $10.99 \%$ & $1.56 \%$ \\
\hline \% Coarse silt & $33.15 \%$ & $29.28 \%$ \\
\hline \% Fine silt & $42.59 \%$ & $42.62 \%$ \\
\hline \% Clay & $13.27 \%$ & $26.54 \%$ \\
\hline$D_{10}$ & $3.4 \mathrm{um}$ & $1.2 \mathrm{um}$ \\
\hline$D_{35}$ & $8.4 \mathrm{um}$ & $4.6 \mathrm{um}$ \\
\hline$D_{50}$ & $13.3 \mathrm{um}$ & $8.0 \mathrm{um}$ \\
\hline$d_{90}$ & $68.1 \mathrm{um}$ & $38.4 \mathrm{um}$ \\
\hline
\end{tabular}

Based on the fines content, a solids concentration of approximately $103 \mathrm{~g} / \mathrm{L}$ was estimated for the dredging slurry. An estimated dredging rate of $0.56 \mathrm{~m}^{3} / \mathrm{s}$, yields a mass rate of $57.8 \mathrm{~kg} / \mathrm{s}$ solids placed during pumping.

\subsubsection{Multivariate erosion rate prediction}

The goal of erosion data analysis is to determine appropriate parameterization of erosion processes for numerical modeling studies. For this study, the erosion data are to be described in the SEDZLJ model. SEDZLJ is flexible in the form of the erosion equation, and the effects of bulk density, depth, and applied shear stress may be represented as indicated by the erosion data. Analysis of the erosion data from the James River dredged sediment suggested that the erosion algorithm should be of the following form:

$$
\begin{array}{cc}
E=0 ; & \left(\tau<\tau_{c}\right) \\
E=A \tau^{n} ; \quad & \left(\tau_{c}<\tau<\tau_{m}\right) \\
E=A \tau_{m}^{n} ; \quad\left(\tau>\tau_{m}\right)
\end{array}
$$

where $E$ represents erosion rate $(\mathrm{cm} / \mathrm{s})$ from the bed, $\tau$ is bed shear stress $(\mathrm{Pa}), \tau_{c}$ is critical stress for erosion (Pa), $A$ is an empirical constant, $n$ is an empirical exponent, and $\tau_{m}$ is bed stress $(\mathrm{Pa})$ at which erosion rate becomes constant, known as the maximum erosion rate. Solution of Equation (3-6) to data requires solving for four parameters, $\tau_{c}, A$, and $n$. Bed stress for the upper limit of the erosion rate is determined by examining the data. The best fit of Equation (3-8) to measured data is 
accomplished through an iterative, multi-parameter, least-squares method on the linear transform of Equation (3-8).

\subsection{Results and discussion}

Cohesive sediment transport process data collected during the laboratory study were analyzed to determine SEDZLJ model parameterizations for cohesive sediment erosion. This section presents results of the data analysis, model parameterization, and general observation with discussion. Laboratory experiments were conducted in October and November 2015.

\subsubsection{Core sample preparation}

Approximately 20 to $25 \mathrm{~L}$ of bed material and $30 \mathrm{~L}$ of native water were collected from the James River. The sediment is comprised primarily of coarse silt that is considered moderately poorly sorted based on the Wentworth classification. Three sets of experiments were conducted to understand changes in critical shear stress and erosion rate as a function of consolidation period. For each experiment, two artificially created, or remoulded, cores were eroded, one original and one replicate, corresponding to 3-day, 10-day, and 30-day consolidation periods. Erosion rates were measured as a function of flow rate using the USACEdeveloped Sedflume. Six cores were initially poured. All cores were permitted to consolidate in a $4^{\circ} \mathrm{C}$ cooler for a designated time prior to erosion experiments. Immediately prior to erosion experiments, cores were visually evaluated for fissures. Two cores had to be re-poured because many fissures were visible through the clear polycarbonate tube. Cores developed in this manner were then eroded in Sedflume. Two cores were eroded for each of the three consolidation periods.

\subsubsection{Core sample erosion}

Each core was scanned for bulk density prior to erosion experiments. Density profiles were evaluated to determine changes in bulk density with depth and consolidation with time. Profiles indicated that density was consistent between cores at approximately $1.3 \mathrm{~g} / \mathrm{cm}^{3}$. In addition, there was little vertical variation in density within each core after the top $5 \mathrm{~cm}$ of each core. The top $5 \mathrm{~cm}$ often included a hardened oxidized layer that did not behave like the underlying sediments. Therefore, the erosion measurements from the top 3 to $5 \mathrm{~cm}$ of each core were removed from the analyzed data set. 
All six cores were eroded in the USACE Sedflume. The protocol described previously in this section was applied. X-radiography density analysis indicated that cores were of consistent density and increased consolidation was nominal after 3 days. The purpose of consolidating cores for various periods of time was to evaluate consolidation as a function of time and quantify the effects of consolidation on erosion rate. Since consolidation was virtually complete after 3 days, as demonstrated by consistent density profiles, data from all cores could be compared to each other. An example density profile is provided in Figure 3-4. In this figure, the sediment/water interface is at approximately $400 \mathrm{~mm}$, and the bottom of the core is at $700 \mathrm{~mm}$. It can be seen that the density is relatively consistent throughout the core with a value of 3.0 to $3.1 \mathrm{~g} / \mathrm{cm}^{-3}$.

Figure 3-4. Density profile for a core consolidated for 3 days.

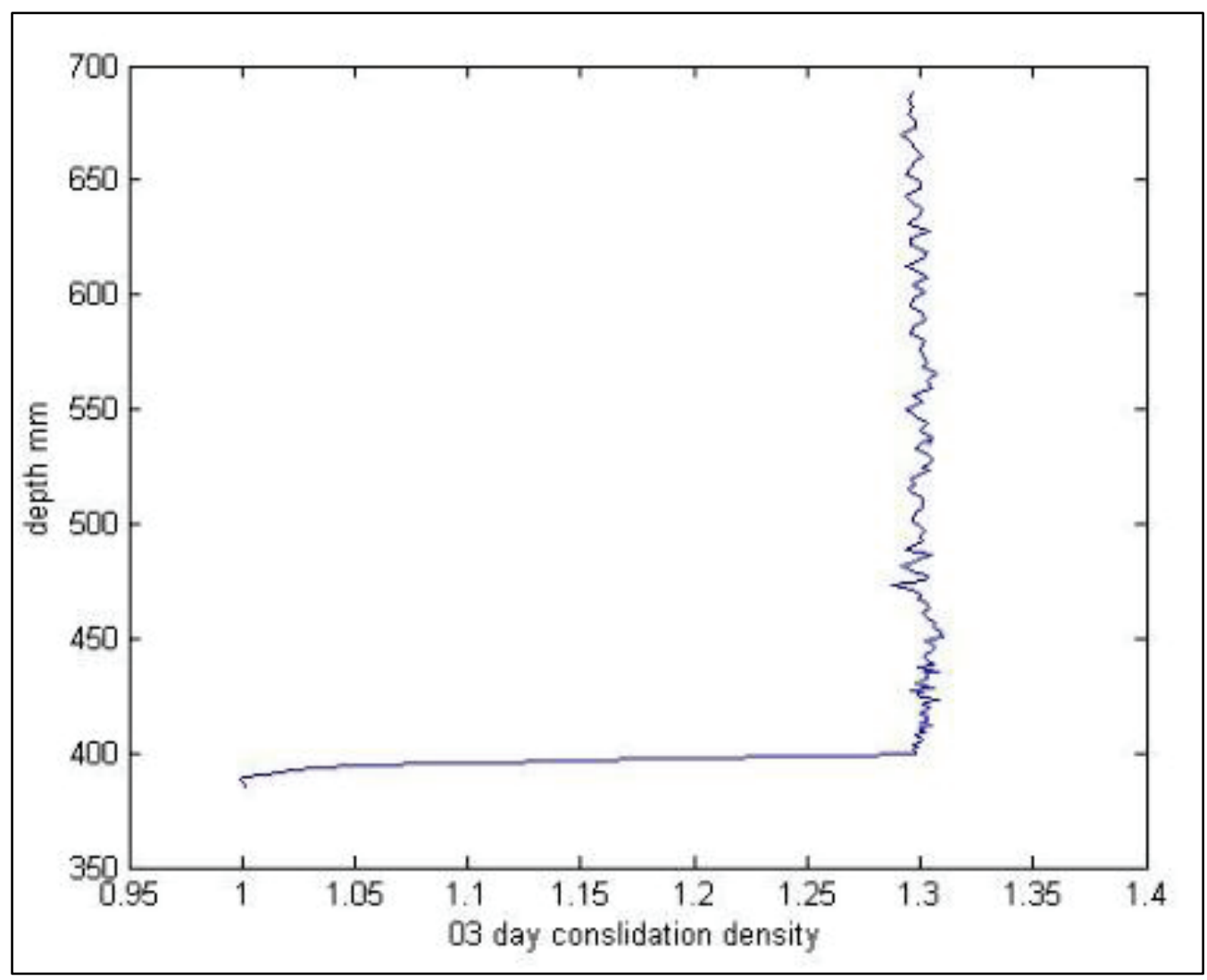

After density profiling, each core was immediately installed in the Sedflume as described above. Erosion experiments were performed as described above. Data were logged and transferred to MATLAB for analysis. Data from each core were evaluated for consistency. Core data were then compared to each other to evaluate erosion trends. Two cores, numbers 2 and 6, eroded differently than the other four and were not 
considered in further analysis. The remaining four core data were grouped and analysis performed. Figure 3-5 shows the shear stress vs. erosion rate for the four cores. The circles are the mean erosion rate at each shear stress, and the bars represent the standard deviation. The curve is the best fit to the data for Equation 3-8. $T \mathrm{cr}$ is evaluated by setting $\mathrm{E}=10^{-4} \mathrm{~cm} / \mathrm{s}$ in Equation 3-6 and solving for $T$ cr. Data analysis represented in Figure 3-5 indicate that the best fit for the James River dredged sediment is summarized in Table $3-2$ as $A=2.4 \times 10^{-4}$ and $n=4.57$. The resulting $T_{c r}=0.83 \mathrm{~Pa} . T \mathrm{~m}$ is defined as the highest erosion rate for which erosion is measurable in Sedflume. For the James River dredged sediment, this corresponds to $T_{m}=2.4 \mathrm{~Pa}$.

Figure 3-5. Erosion data for Station $\mathrm{CHO} 2$ showing increasing erosion resistance with depth up to $9 \mathrm{~cm}$ below the original sediment/water interface due to increasing density. Erosion is relatively constant below $9 \mathrm{~cm}$ (within measurement error) because bed density is constant.

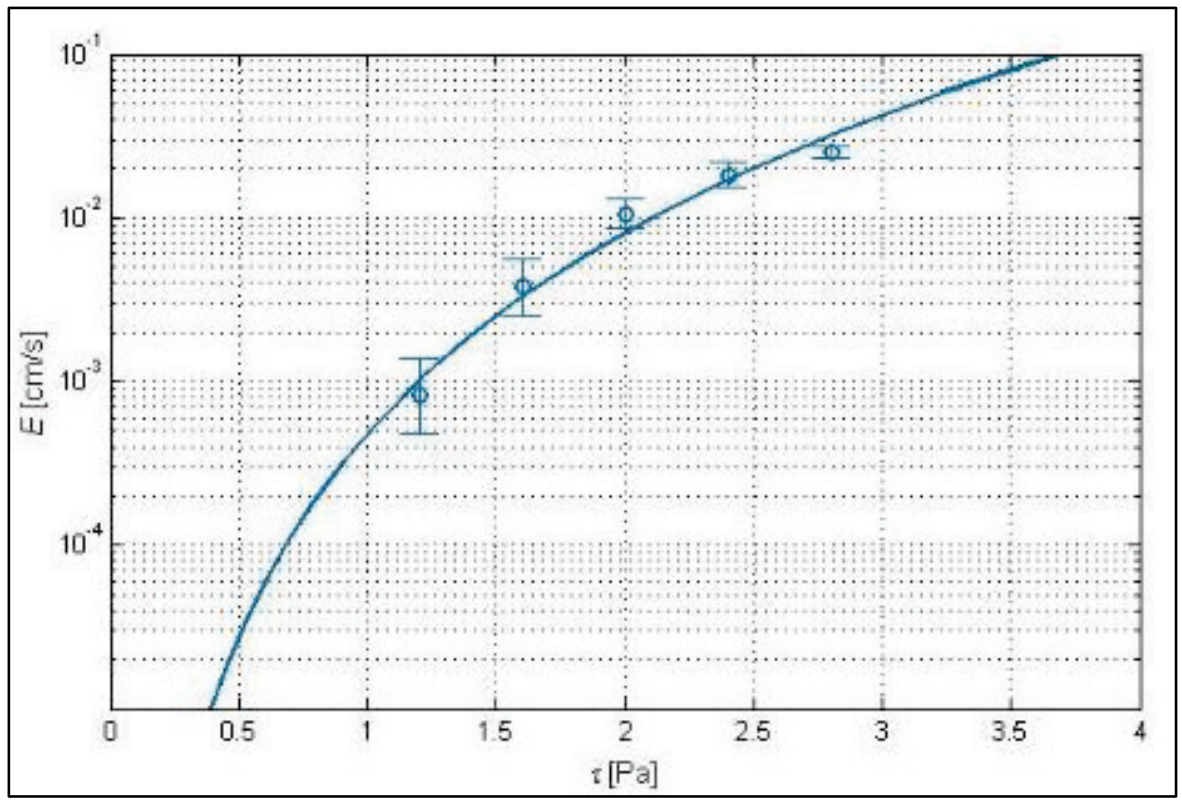

Table 3-2. Values of parameters in Equation 3-6 for James River dredged sediments.

\begin{tabular}{|c|c|c|c|}
\hline$\tau_{\text {cr }}(\mathrm{Pa})$ & $\operatorname{Tm}(\mathrm{Pa})$ & $\mathrm{A}$ & $\mathrm{n}$ \\
\hline 0.83 & 2.8 & $2.4 \times 10^{-4}$ & 4.57 \\
\hline
\end{tabular}




\section{Source Term Development}

Dredging operations can release sediment into the water column during placement. One goal of this work is to characterize (amount, location, temporal changes if any) the dredged sediment released in the water column and predict the fate of that sediment. Figure 4-1 shows a dredging operation at the James River. Shown is the discharge zone with the dredge in the background. The discharge end is typically supported at a 20-degree discharge angle to the water surface with the bottom of the pipeline end at a depth of $3 \mathrm{ft}$ below the water surface. Also required is use of a baffle plate or other approved apparatus to the discharge end of the dredge pipeline, which reduces head pressure, helps control the placement of dredged material, and increases the settlement rate of the material.

Figure 4-1. Pipeline placement at James River (photo by NAO).

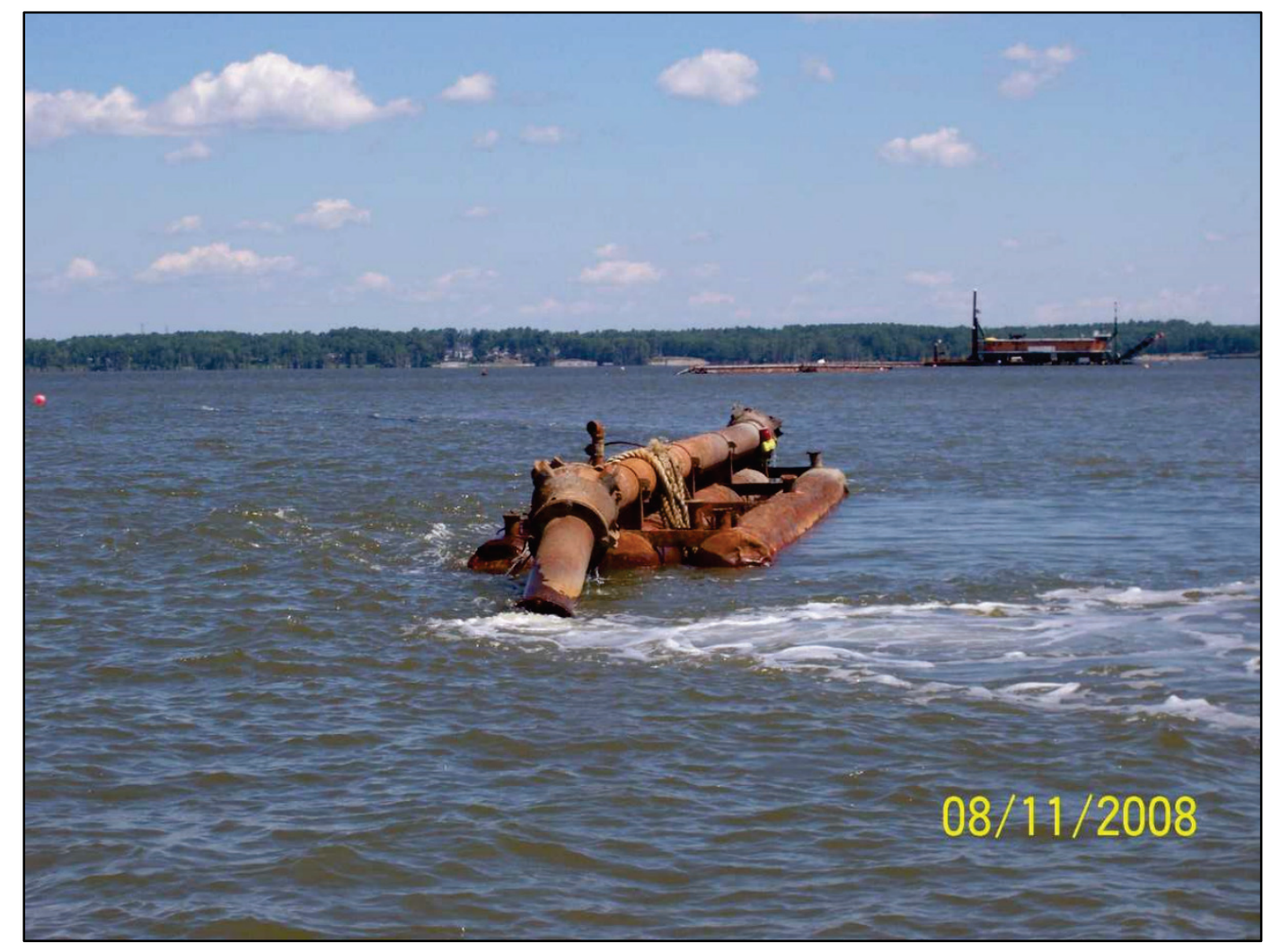

Several models are available to predict the resulting plume generated by pipeline discharge. As material is pumped into the placement area, most of the material readily settles and may flow as a density flow along the bottom. Only a portion of the particles is stripped and suspended and available for transport. Information about the plume is used to determine 
the mass of sediment available in the water column for long-term transport, which is modeled by the PTM as described in Chapter 5 . This chapter describes laboratory testing and modeling performed to determine a source term for further modeling using PTM.

\subsection{Dredging operation}

The James River channel from Dancing Point to Swann Point is dredged hydraulically by a cutterhead dredge. The dredged material is pumped directly from the dredge via a pipeline and discharged at discrete points within the disposal area located to the south of the channel (Figure 1-1). Dredging operations are not allowed from 15 February to 30 June to protect sensitive environmental resources. Dredging logs were provided from recent dredging, which were used to determine typical operations. From the logs, three dredges have been employed including 14 in., 16 in., and 19 in. dredges. Pipeline lengths ranged between 3,480 and 3,900 ft. Given the 2,000 $\mathrm{ft}$ distance between the channel and centerline of the placement area, a dredge may clear approximately $6,000 \mathrm{ft}$ of the channel before moving the pipeline to the next discharge point, typically taking several days. Contract specifications provided by the district indicate that material is discharged with the bottom of the pipeline $3 \mathrm{ft}$ below the water surface, at a 20-degree discharge angle using a baffle plate. The velocity of slurry in the pipeline is approximately $18.5 \mathrm{ft} / \mathrm{s}$, although the baffle plate will slow the exit rate considerably.

\subsection{Sediment characteristics}

As discussed in Chapter 3, grain size analysis was performed by two separate methods (Table 3-1). The Method 2 results were selected for use as having a greater percentage of fines that would conservatively predict more particulate transport. However, adjustments were made to account for aggregation of fine particles as described in this chapter (Table 4-1). Data from hopper and mechanical dredging sites suggest that very little fine-grained dredged material is completely disaggregated into individual silt and clay particles* (Smith and Friedrichs 2010). The fine-grained portion released in the water column consists of a range of aggregated sediments, including flocculated particles, and fragments of the dredged

\footnotetext{
* Smith, S. J., and C. Friedricks. In preparation. PICS Characterization of Bucket Dredging Operations in Boston Harbor. Vicksburg, MS: US Army Engineer Research and Development Center.
} 
sediment bed with relatively large densities. Based on this data, only $7 \%$ of the masses of fine silt and clay were assumed to be disaggregated, and the other $93 \%$ assumed to be in the form of bed aggregates or flocculated fine sediment. The fines assumed to be flocculated or bed aggregates were assigned the properties of coarse silt and therefore are shown in the coarse silt category in the adjusted grain size distribution (Table 4-1).

Table 4-1. Grain size distribution results.

\begin{tabular}{|l|l|l|l|}
\hline & Method 1 & Method 2 & $\begin{array}{l}\text { Method 2, } \\
\text { adjusted* }\end{array}$ \\
\hline \% Sand & $10.99 \%$ & $1.56 \%$ & $1.56 \%$ \\
\hline \% Coarse silt & $33.15 \%$ & $29.28 \%$ & $93.60 \%$ \\
\hline \% Fine silt & $42.59 \%$ & $42.62 \%$ & $2.98 \%$ \\
\hline \% Clay & $13.27 \%$ & $26.54 \%$ & $1.86 \%$ \\
\hline
\end{tabular}

*Adjusted to account for particles in bed aggregates and flocs.

Based on the fines content, a solids concentration of approximately $103 \mathrm{~g} / \mathrm{L}$ was estimated for the dredging slurry. An estimated dredging rate of $0.56 \mathrm{~m}^{3} / \mathrm{s}$ yields a mass rate of $57.8 \mathrm{~kg} / \mathrm{s}$ solids placed during pumping.

\subsection{Site data}

Six separate locations were considered for modeling to incorporate a range of depth, velocity, and slope conditions (Figure 4-2). The stations are denoted P1-P6 and then given additional nomenclature based on their positions adjacent to the channel station locations. Hydrodynamic conditions at each point were provided by the $\mathrm{CH}_{3} \mathrm{D}$ model results described in Chapter 2 for year 2000, time periods 1 January-31 March and 29 June-27 September. Mean conditions within the allowable dredging period were determined at each location and are summarized in Table 4-2. 
Figure 4-2. Locations along James River selected for modeling.

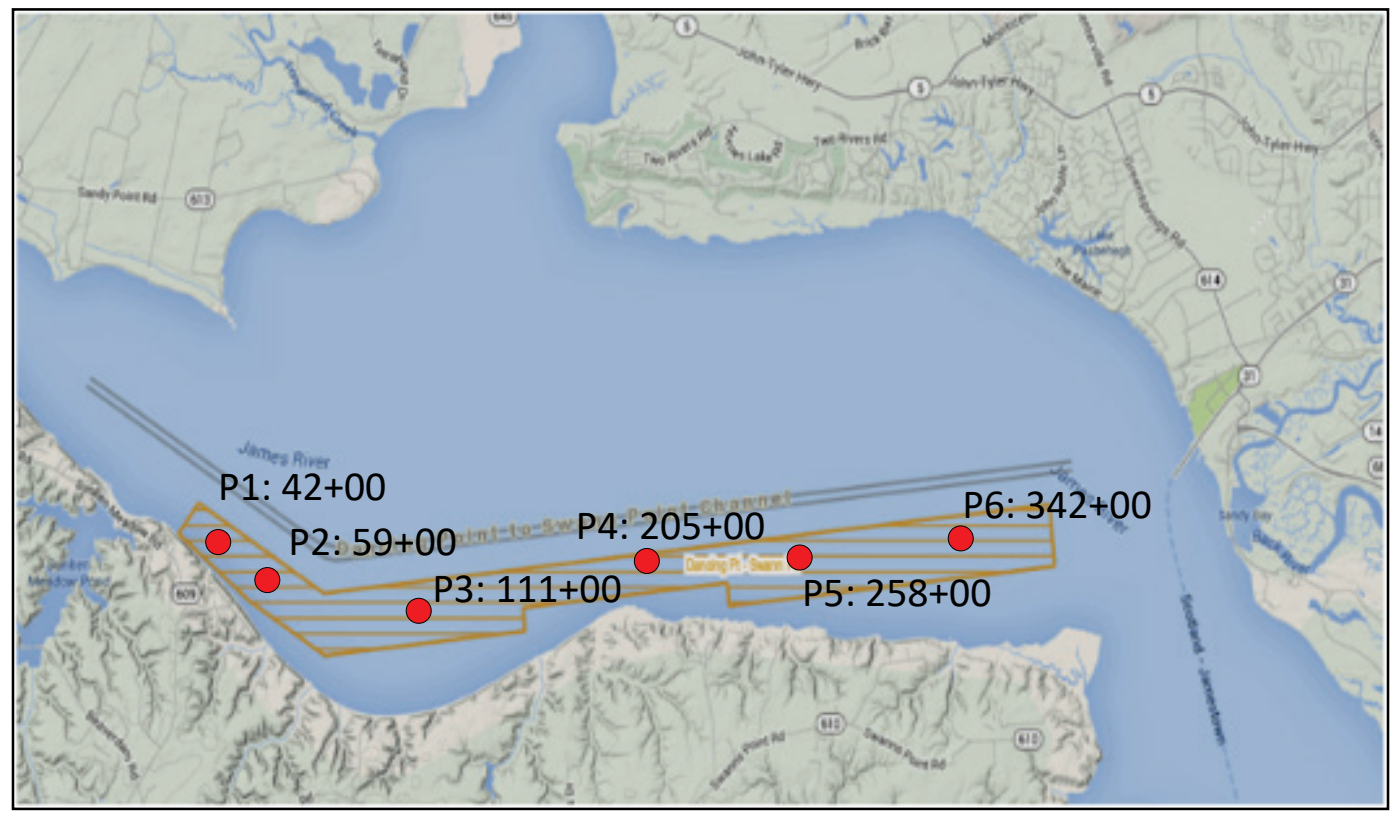

Table 4-2. Site-specific data relevant to modeling.

\begin{tabular}{|c|c|c|c|c|c|c|}
\hline $\begin{array}{l}\text { Point } \\
\text { Station }\end{array}$ & $\begin{array}{l}P 1 \\
42+00\end{array}$ & $\begin{array}{l}P 2 \\
59+00\end{array}$ & $\begin{array}{l}\text { P3 } \\
111+00\end{array}$ & \begin{tabular}{|l} 
P4 \\
$205+00$
\end{tabular} & \begin{tabular}{|l} 
P5 \\
$258+00$
\end{tabular} & $\begin{array}{l}P 6 \\
342+00\end{array}$ \\
\hline $\begin{array}{l}\text { UTM X } \\
\text { coordinate }\end{array}$ & 329581.8 & 329937.2 & 331736.6 & 334601.1 & 336251.3 & 338724.8 \\
\hline $\begin{array}{l}\text { UTM Y } \\
\text { coordinate }\end{array}$ & 4120600 & 4120215 & 4119583 & 4119965 & 4120003 & 4120230 \\
\hline $\begin{array}{l}\text { Water depth } \\
\text { (average), } \mathrm{m}\end{array}$ & 4.91 & 1.83 & 1.50 & 5.48 & 3.44 & 2.55 \\
\hline $\begin{array}{l}\text { Ambient } \\
\text { velocity } \\
(\mathrm{m} / \mathrm{s})\end{array}$ & 0.2991 & 0.2159 & 0.1134 & 0.2473 & 0.2220 & 0.2147 \\
\hline $\begin{array}{l}\text { Mean } \\
\text { surface } \\
\text { density } \\
\left(\mathrm{kg} / \mathrm{m}^{3}\right)\end{array}$ & 997.84 & 997.84 & 997.87 & 997.91 & 997.94 & 997.97 \\
\hline $\begin{array}{l}\text { Mean } \\
\text { surface } \\
\text { salinity (ppt) }\end{array}$ & .02424 & .02587 & .05599 & .11685 & .15010 & .18932 \\
\hline $\begin{array}{l}\text { Mean } \\
\text { bottom } \\
\text { salinity (ppt) }\end{array}$ & .02433 & .02587 & .05599 & .11724 & .15017 & .18937 \\
\hline $\begin{array}{l}\text { Channel } \\
\text { slope }(\mathrm{m} / \mathrm{m})\end{array}$ & .0525 & .0150 & .0029 & .0189 & .0094 & .0050 \\
\hline
\end{tabular}




\subsection{Modeling}

A number of models were applied for development of the source term based on an understanding of the material behavior upon discharge and how the discharge is represented within each of the models. Upon discharge, the dredged material slurry will exit the discharge pipe as a jet and plunge to the sediment bed, although the baffle plate will slow the velocity and cause the material to exit in a radial fashion. The material will flow along the bottom as a density current and then deposit on the sediment bed, although a portion will be stripped and suspended in the water column. The stripped mass is that which is available for transport and will become the source term for the PTM modeling effort.

\subsubsection{D-CORMIX}

D-CORMIX (Doneker and Jirka 1991) predicts movement and dilution of a dredged material discharge, progressing through near-field jet mixing, plume mixing, a density current, and far-field ambient mixing of the plume solids into the water column. D-CORMIX focuses on the movement and dilution of a mixture of solids and liquids as a jet or plume and as a density current. It does not account for the distribution within the water column of a component stripped from the sinking plume or entrained from bottom deposits. D-CORMIX models the jet underflow in the water column, allowing particles to settle out. Figure 4-3 shows the percent mass remaining as the discharge plume travels downstream as predicted by D-CORMIX.

Figure 4-3. Total sediment mass flux remaining as predicted by D-CORMIX.

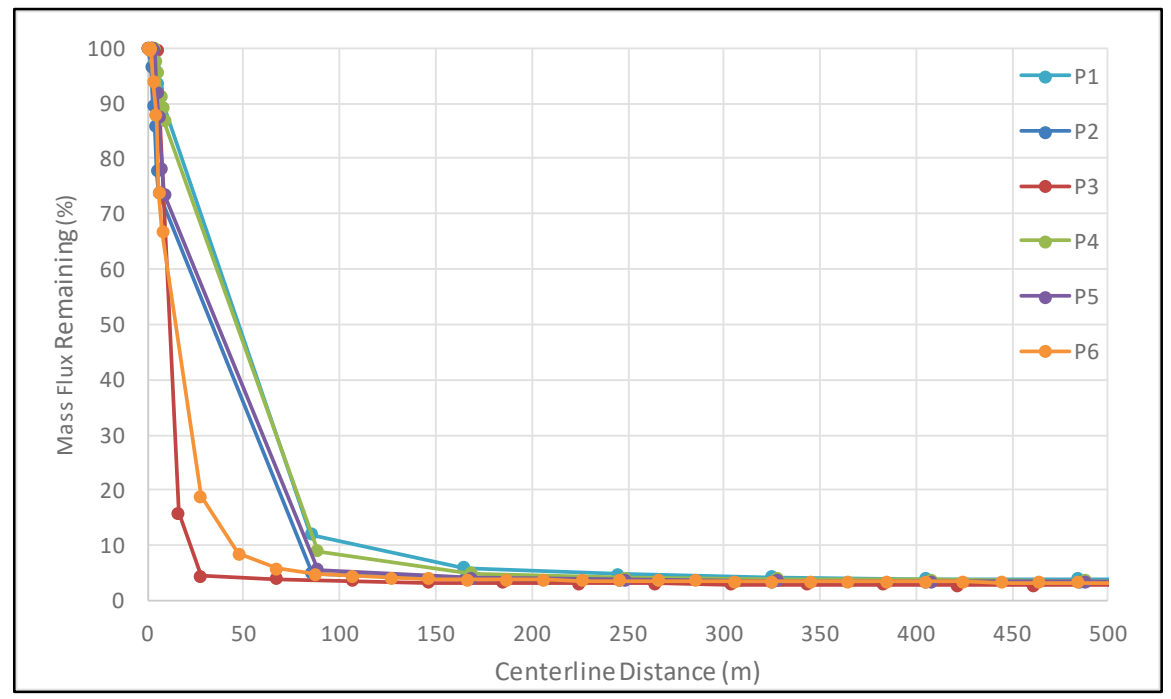




\subsubsection{DIsposal From a Continuous Discharge (DIFCD\}}

The DIFCD model (Brandsma and Divoky 1976) was developed for prediction of deposition of solid material on the bottom in the hours after discharge. DIFCD models both the density flow and the water column, although the model is not extremely robust. Results were only obtained at three of the six locations and varied a great deal. Figures 4-4 and 4-5 show the percent of the discharged solids remaining at distances downstream from the discharge.

Figure 4-4. Discharged solids remaining at distances downstream of the discharge from Point 2.

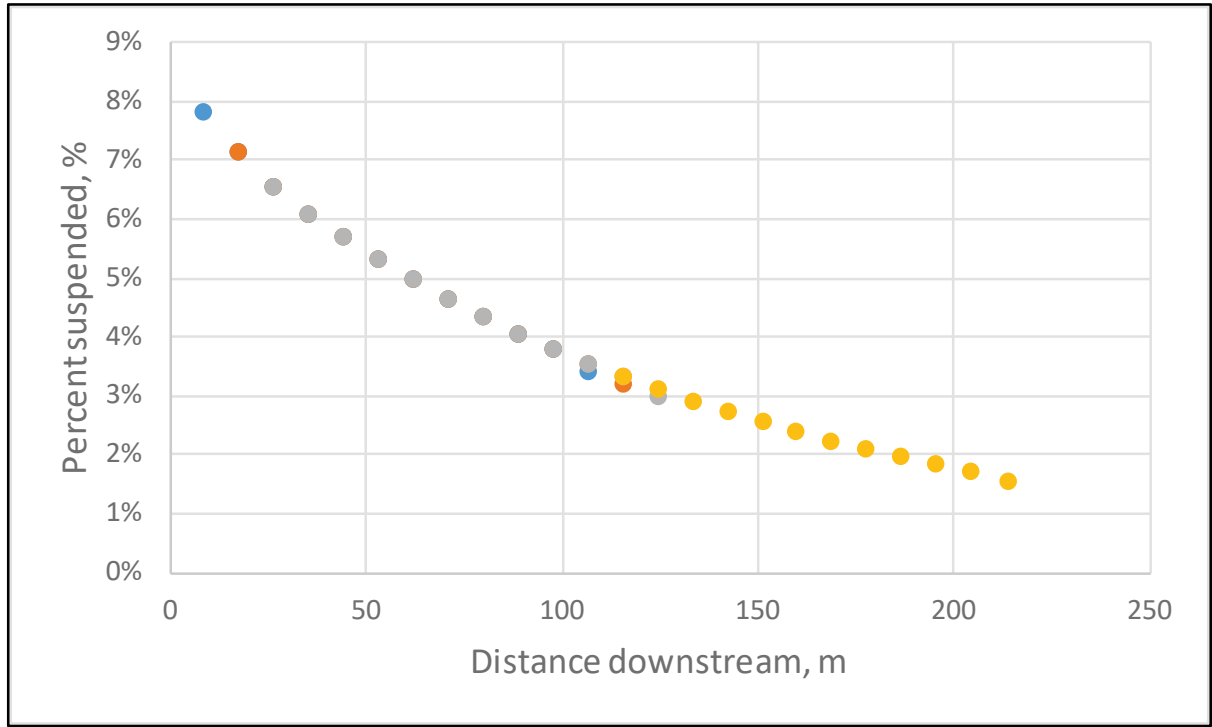

Figure 4-5. Discharged solids remaining at distances downstream of the discharge from Point 3.

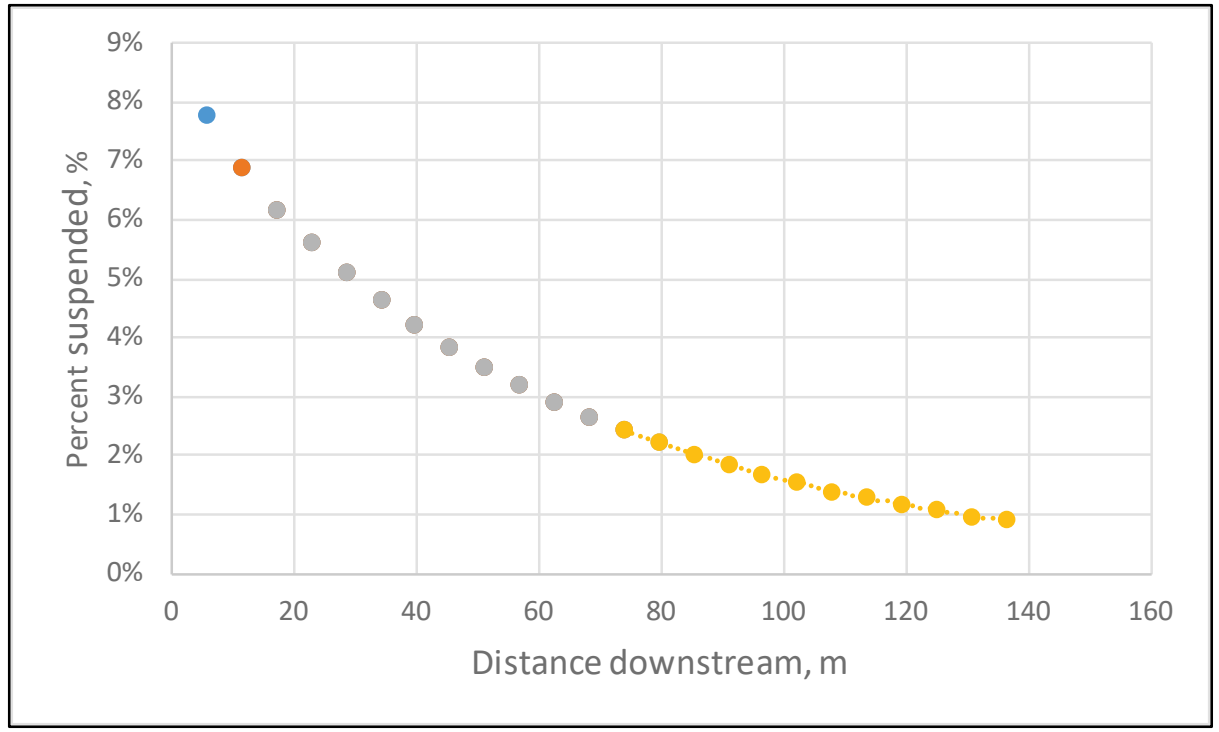




\subsubsection{DREDGE}

The DREDGE model ${ }^{*}$ was also applied. The DREDGE model is used to represent diffusion of the turbidity plume resulting from the dredging end of either a cutterhead or clamshell dredge. However, the discharge end can be modeled by assuming the mass rate of sediment resuspension to be the mass release rate from the pipeline. Because it is intended for turbidity at the dredge head, the plume for the cutterhead is a point source originating on the bottom.

DREDGE was applied by determining the suspended concentrations at locations within a plane at distances along the plume centerline for particle settling velocities representative of each size class. The results were then compared to concentrations resulting from model runs using a zero settling velocity to calculate the percent of solids in each size class that would remain suspended. The mass rate was then calculated by multiplying the mass release rate for each fraction by the percent suspended. Settling velocities applied for each size class, shown in Table 4-3, were calculated using Stokes Law for particle diameters $82.5 \mu \mathrm{m}, 45 \mu \mathrm{m}, 10 \mu \mathrm{m}$, and $2 \mu \mathrm{m}$ to represent the size classes for sand, coarse silt, fine silt and clay, respectively. Results are dependent on the diffusion coefficients, which are calculated based on water depth and velocity which differs at the six locations. Figure 4-6 shows the total solids mass in suspension resulting from discharges at each of the locations.

Table 4-3. Particle settling velocity applied to the DREDGE model for each size class.

\begin{tabular}{|l|l|l|l|l|}
\hline & Sand & Coarse Silt & Fine Silt & Clay \\
\hline Settling velocity, $\mathrm{m} / \mathrm{s}$ & $6.096 \mathrm{E}-03$ & $1.814 \mathrm{E}-03$ & $8.956 \mathrm{E}-05$ & $3.582 \mathrm{E}-06$ \\
\hline Mass release rate, $\mathrm{kg} / \mathrm{s}$ & 0.90 & 54.05 & 1.72 & 1.07 \\
\hline
\end{tabular}

* Hayes, D. F., and C. H. Je. 2000. DREDGE Module User's Guide. Unpublished draft. Vicksburg, MS: U.S. Army Engineer Research and Development Center. https://dots.el.erdc.dren.mil/elmodels/pdf/dredge.pdf 
Figure 4-6. Mass of solids remaining in suspension as predicted by DREDGE model calculations.

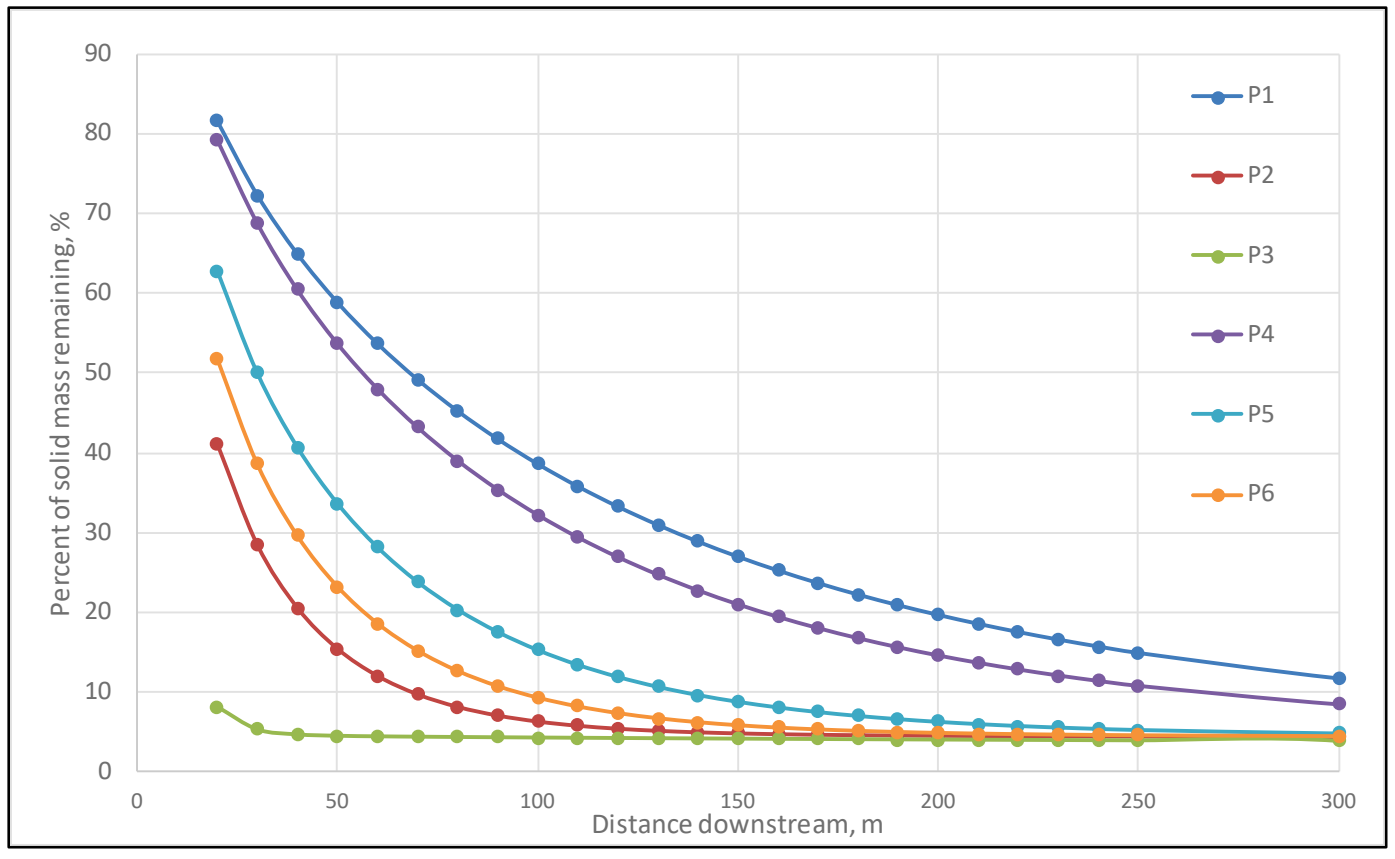

\subsection{Laboratory analyses}

Two laboratory experiments were conducted to determine if the model results are realistic. Each experiment was a small-scale settling test performed to collect flocculent settling data. This first test was conducted in a $4 \mathrm{~L}$ graduated cylinder ( 4 in. diameter). The small-scale column settling test provides data on the fraction of solids remaining in the water column versus the fraction that settles to the bottom. Based on the D-CORMIX modeling results, it appears that the released slurry would entrain water to a solids concentration of approximately $30 \mathrm{~g} / \mathrm{L}$ during jet descent. Therefore, a slurry of James River sediment at $27 \mathrm{~g} / \mathrm{L}$ was poured into the cylinder. The height of the solids interface was recorded over time, and samples were taken from near the middle of the water column for total suspended solids analysis. Analysis of the resulting data (Figure 4-7) showed that the solids fraction remaining in the water column was approximately 6\% after 15 minutes and dropped to near $2 \%$ after 4 hours. 
Figure 4-7. Fraction solids (mass) remaining in water column during small-scale column settling test.

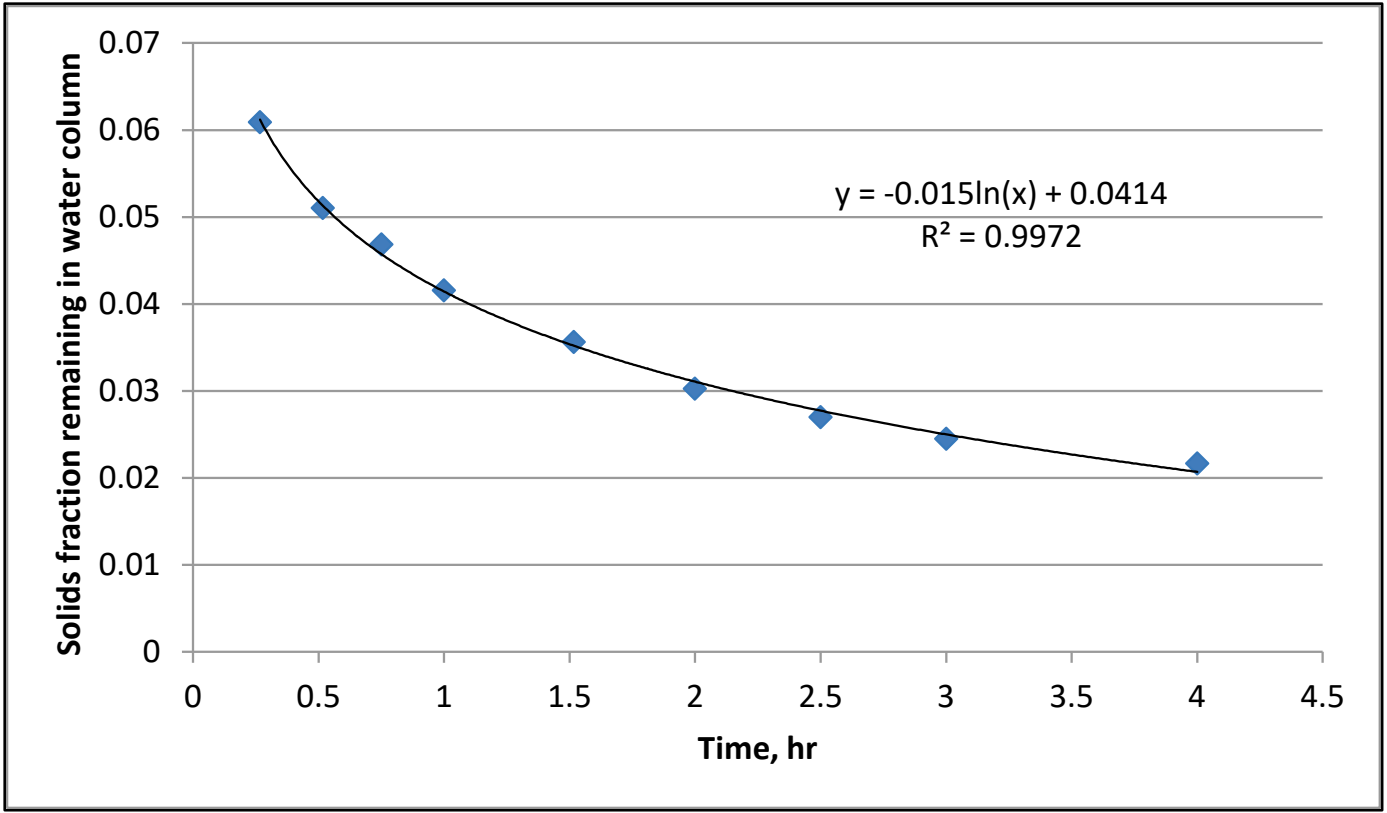

The second test was conducted using a $102 \mathrm{~g} / \mathrm{L}$ slurry, similar to that discharged from the dredge, which was pumped into approximately $1.6 \mathrm{ft}$ of water in an $8 \mathrm{in}$. diameter column. Approximately $3.5 \mathrm{in}$. of slurry was pumped at a pipeline velocity of approximately $10 \mathrm{ft} / \mathrm{s}$, although the slurry rapidly expanded as it entrained water. A baffle plate was affixed to the end of the pipeline to reduce the discharge velocity, simulating that found in the field. Samples were taken over time at four water depths. The mass fraction of the solids remaining in the water column was determined for each height interval, and the total fraction of suspended solids. Similar to the column settling test, the mass fraction remaining dropped from approximately $6 \%$ after 5 minutes to $1.5 \%$ after 5 hours (Figure $4-8$ ). 
Figure 4-8. Fraction solids (mass) remaining in water column after pumping sediment slurry into $1.6 \mathrm{ft}$ of water.

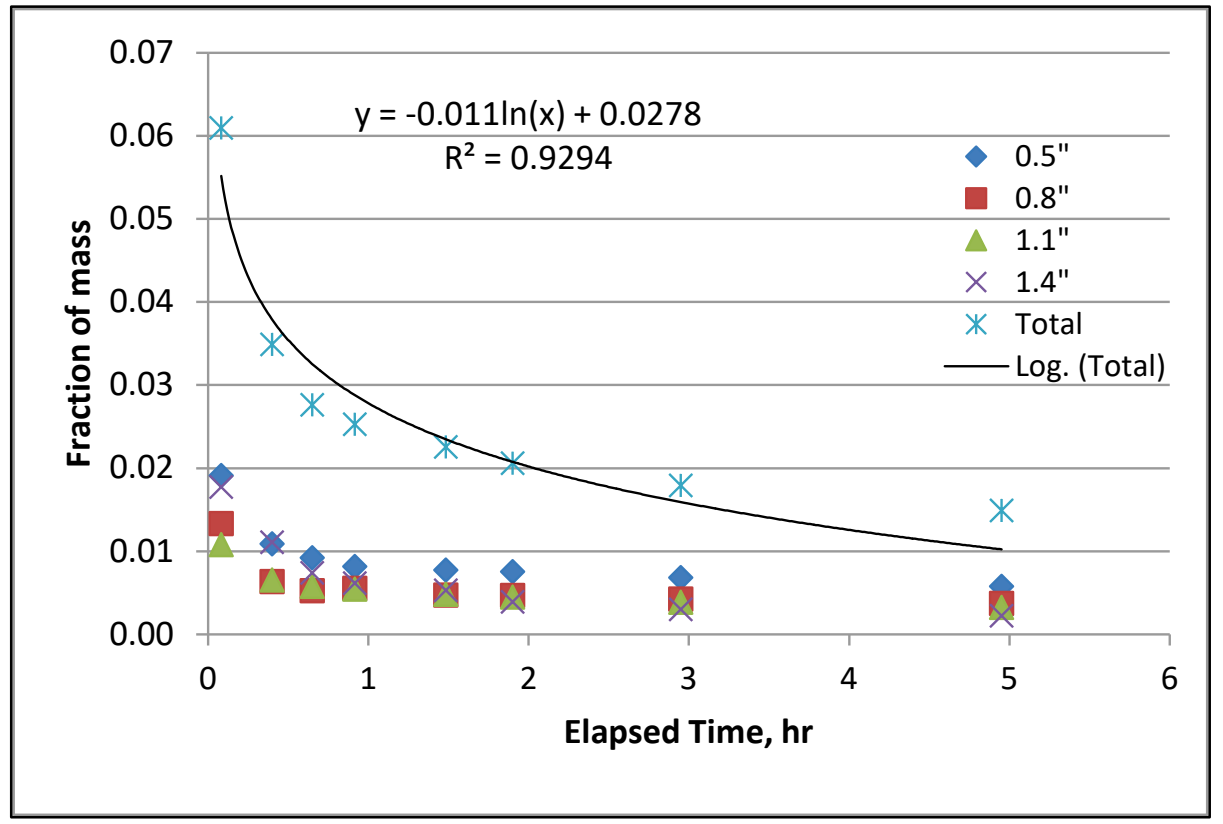

\subsection{Comparison of results}

Results from the various models and laboratory tests were compiled to generate an estimate of the suspended solids available for transport. As previously discussed, the discharge slurry initially descends through the water column as a jet plume, eventually flowing as a dense layer on the bottom, with some of the material being stripped off. The stripped material also diffuses and settles over time as well. Therefore the suspended concentration is changing with time and distance from the discharge. To compare results and for selection of a PTM source term, a time or distance was selected where it could be assumed that the slurry had transitioned from the jet plume. Results predicted by the different models or laboratory tests at a distance of $150 \mathrm{~m}$ are shown in Table 4-4.

Table 4-4. Percent solids remaining predicted by laboratory tests and different models at $150 \mathrm{~m}$ from the discharge point.

\begin{tabular}{|l|l|l|l|l|l|l|}
\hline $\begin{array}{l}\text { Point } \\
\text { Station }\end{array}$ & Pt 1 & Pt 2 & Pt 3 & Pt 4 & Pt 5 & Pt 6 \\
$\mathbf{4 2 + 0 0}$ & $59+00$ & $\mathbf{1 1 1 + 0 0}$ & $\mathbf{2 0 5 + 0 0}$ & $\mathbf{2 5 8 + 0 0}$ & $\mathbf{3 4 2 + 0 0}$ \\
\hline DREDGE & 27.0 & 4.8 & 4.2 & 21.0 & 8.8 & 5.9 \\
\hline D-CORMIX & 7.1 & 4.1 & 3.3 & 5.9 & 4.4 & 4.0 \\
\hline DIFCD & & 2.6 & 0.7 & & & \\
\hline 4 in. column test & 7.10 & 6.61 & 5.64 & 6.81 & 6.65 & 6.60 \\
\hline 8 in. column test & 4.96 & 4.44 & 3.57 & 4.65 & 4.49 & 4.44 \\
\hline
\end{tabular}


With the exception of a couple of high estimates from the DREDGE model and a low estimate from the DIFCD model, the results suggest a range between $3 \%$ and $7 \%$ of the total solids remaining in suspension. The results also suggest a greater fraction of the solids will be suspended in the locations where the channel is deeper and with higher velocities such as at Point 1 and Point 4. The D-CORMIX results appear to provide the most reasonable data set and were used for selection of a source term for each location as shown in Table 4-5. In addition to the mass rate, the vertical thickness and diameter of the area in which the source is contained is also provided by D-CORMIX.

Table 4-5. Mass source description for discharge at each location.

\begin{tabular}{|l|l|l|l|l|l|l|}
\hline \multirow{2}{*}{ Point Station } & $\begin{array}{l}\text { Pt 1 } \\
\mathbf{4 2 + 0 0}\end{array}$ & $\begin{array}{l}\text { Pt 2 } \\
59+00\end{array}$ & $\begin{array}{l}\text { Pt 3 } \\
111+00\end{array}$ & $\begin{array}{l}\text { Pt 4 } \\
\mathbf{2 0 5 + 0 0}\end{array}$ & $\begin{array}{l}\text { Pt 5 } \\
\mathbf{2 5 8 + 0 0}\end{array}$ & $\begin{array}{l}\text { Pt 6 } \\
\text { 342+00 }\end{array}$ \\
\hline \multicolumn{7}{|l|}{ Discharge rate, kg/s } \\
\hline Sand & 0 & 0 & 0 & 0 & 0 & 0 \\
\hline Coarse silt & 1.038 & 0.065 & 0.0054 & 1.508 & 0.114 & 0.086 \\
\hline Fine silt & 1.344 & 1.128 & 0.988 & 1.285 & 1.169 & 1.148 \\
\hline Clay & 1.064 & 1.057 & 1.053 & 1.062 & 1.059 & 1.058 \\
\hline Horizontal spread, $\mathrm{m}$ & 75.88 & 87.02 & 145.36 & 88.02 & 89.70 & 84.92 \\
\hline Vertical thickness, $\mathrm{m}$ & 1.42 & 1.34 & 1.04 & 1.47 & 1.40 & 1.23 \\
\hline
\end{tabular}

\subsection{Conclusion}

A variety of sediment transport models were used to determine the suspended solids available for transport upon pipeline discharge from a cutterhead dredge. As the models are designed for different purposes and model different phenomenon, different results were obtained. Two simple laboratory tests were conducted to back up the modeling effort. In general, the results of both the modeling and laboratory work seem to suggest the range between $3 \%$ and $7 \%$ of the total solids remaining in suspension, which is in agreement with what is generally thought to occur in the field. As the D-CORMIX results seemed to provide the most reasonable data and necessary detail, these results were used to generate source terms for discharge at each location. 


\section{$5 \quad$ Far-Field Suspended Loss Transport Modeling (PTM Modeling)}

Utilizing the loss term predicted in Chapter 4 and hydrodynamics from Chapter 2, transport of sediment suspended during mound formation (the placement process) is modeled by PTM (McDonald et al. 2006; Gailani et al. 2016) for a 1-month period. The focus of this chapter is to determine the fate of this initial sediment source. The amount of this loss from the total mass of placed material generally ranges from $1 \%$ to $5 \%$ of the total mass of sediment placed. Source term modeling for these particular sediments (Chapter 4) predicts loss terms ranging from $3 \%$ to $7 \%$ based on conservative estimates.

The purpose of modeling the fate of this sediment is to assess WQ within the area of interest due to potential increased suspended sediment concentration and deposited material. Although within the current work, these data are used to develop a general understanding of the transport and WQ, and this information may ultimately be paired with effects data to determine risk to relevant environmental receptors in the area.

PTM is a Lagrangian model that simulates particulate movement in a flow field which models such processes as settling, deposition, re-suspension, and particle-bed interactions to simulate the transport of both fine and coarse sediment. PTM requires the input of hydrodynamics (i.e., water surface elevation and velocities), mesh and bathymetry information, and sediment characterization of both the native or bed sediment and the sediment sources (Figure 3-1). These sources may initiate from sediment re-suspended during dredging and/or placement. Instead of modeling every grain of sand, silt, and clay, sediment is discretized into parcels. Each parcel is representative of a specific mass of sediment. These parcels preserve the overall size distribution and total mass of the sediment source. The model then steps through time tracking the position of each parcel. PTM output includes time-accurate horizontal and vertical positions of sediment parcels. Other attributes such as mass, density, and suspension status are also assigned to each of the output parcels.

Particle settling parameters may be user defined based on site-specific data or determined by algorithms based on verified theoretical and empirical relationships. For this application, particle size and density were 
determined by the sediment source characterization described in Chapter 4. Settling rates were unknown, so a range of settling rates was modeled based on theoretical relationships within PTM as well as additional knowledge of sediment settling within the area.

\subsection{Simulation details}

The dredging scenarios chosen for PTM modeling were selected based on dredge history data provided by NAO. Table $5-1$ shows the details of recent dredging operations within the area of interest. The dredging operations vary based on dredge, which then affects other characteristics such as production rate. Average values are shown in the final column of the table. These values were utilized for the PTM modeling.

Due to dredging restrictions that begin in mid-February for this area, the month-long PTM simulation period is from 14 January 2000-14 February 2000. Dredging occurs over the first 17 days, and then the simulation continues for an additional 2 weeks to allow the finer sediment to either deposit or be transported away from the system.

Table 5-1. Details of dredging operations.

\begin{tabular}{|l|c|c|c|c|}
\hline \multicolumn{5}{|c|}{ Dredging History } \\
\hline Dredging period & $\begin{array}{r}8 / 7 / 14- \\
8 / 15 / 14\end{array}$ & $\begin{array}{c}1 / 15 / 13- \\
1 / 21 / 13\end{array}$ & $\begin{array}{c}12 / 28 / 14- \\
1 / 17 / 15\end{array}$ & Average \\
\hline Dredge & Rockbridge & Jeri B & Marion & \\
\hline Dredge Size & 19 in. & 14 in. & 16 in. & 16.3 in. \\
\hline HP & 2,600 & 2,400 & 1,000 & 2,000 \\
\hline Discharge length, ft & 3,480 & 3,900 & 3,480 & 3,620 \\
\hline *CY/day & 8,409 & 6,748 & 4,952 & 6,703 \\
\hline *CY/hr (during pumping) & 339 & 350 & 259 & 316 \\
\hline *Daily pumping time, hr & 20.9 & 19.1 & 16.7 & 18.9 \\
\hline *Advance per day, ft & 741 & 1284 & 402 & 809 \\
\hline Width of cut & 150 & 100 & 150 & 133.3 \\
\hline
\end{tabular}




\subsection{Source characterization}

\subsubsection{Location}

Using the initial six potential source locations described in the Chapter 4 (Figure 4-1), three release positions were selected that are believed to characterize the variations in hydrodynamic conditions of the entire placement site. Separate 1-month PTM simulations were performed for each release position, assuming that placement occurred at that location within the dredging period. This assumption is supported by the dredging data for the area that shows that the pipeline is often stationary for 2 weeks of dredging. PTM release/source points 2, 4, and 6 are located on the placement site adjacent to channel stations 59+00, 205+00, and 342+00, respectively (Figure 5-1)

Figure 5-1. Initial source locations for PTM simulations.

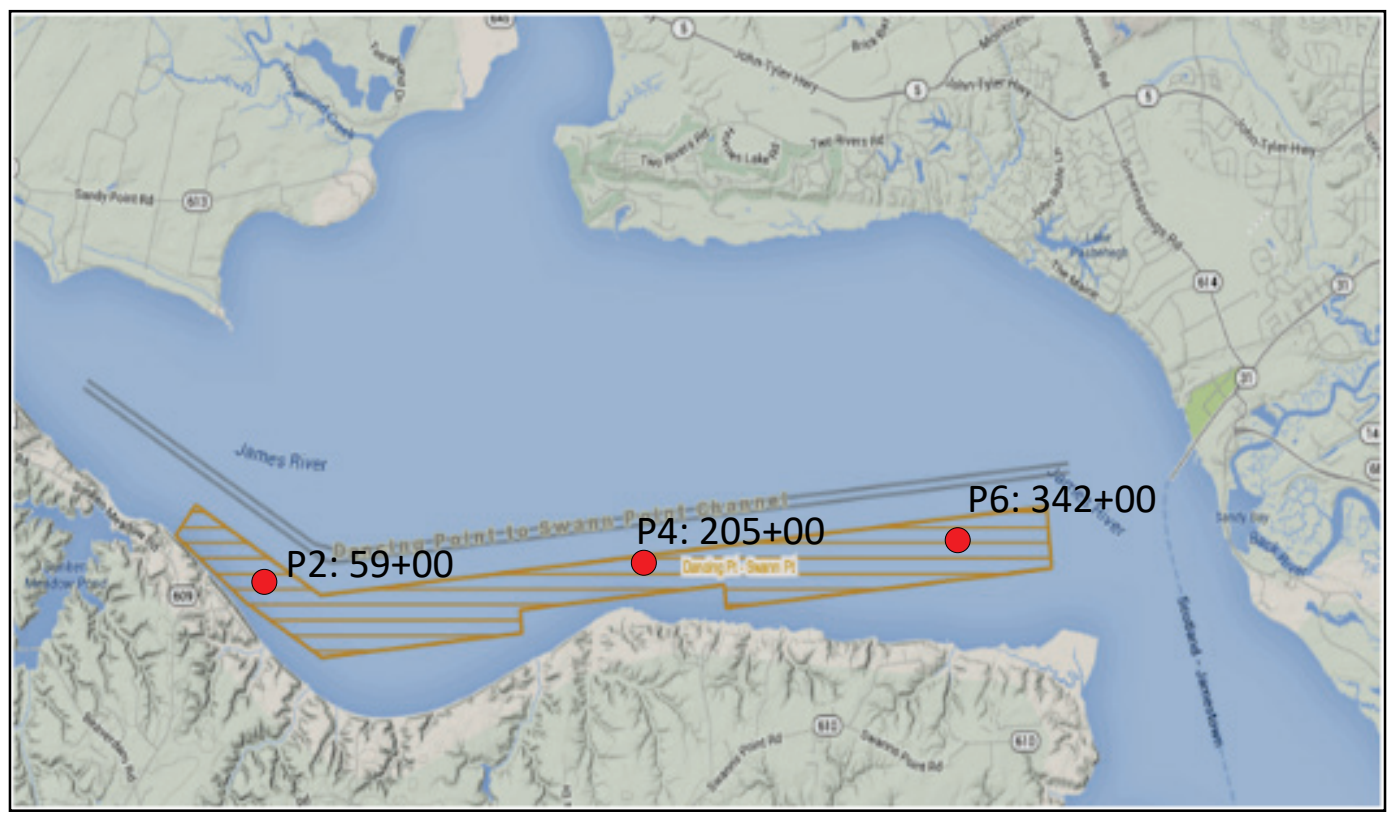

\subsubsection{Hydrodynamics}

Hydrodynamic conditions are slightly varied across the placement site. Because the velocity experienced at the release locations will determine the initial transport, information can be gained by examining the time series of the velocity magnitude during the dredging period at each location. Figure 5-2 shows the hydrodynamic conditions at the initial source locations. The mid-point ( $\mathrm{P}-4)$ position experiences the largest velocities, which suggest the initial transport away from the release location may be most evident at that position. However, because of the higher velocities, 
larger mass rate source terms are experienced at the $\mathrm{P} 4$ location as well. The greatest velocities overall occur between January 18 and January 26. By the end of the dredging period (January 14-January 31), the velocities across the placement site appear to have similar magnitudes.

Figure 5-2. Hydrodynamic conditions at source locations.

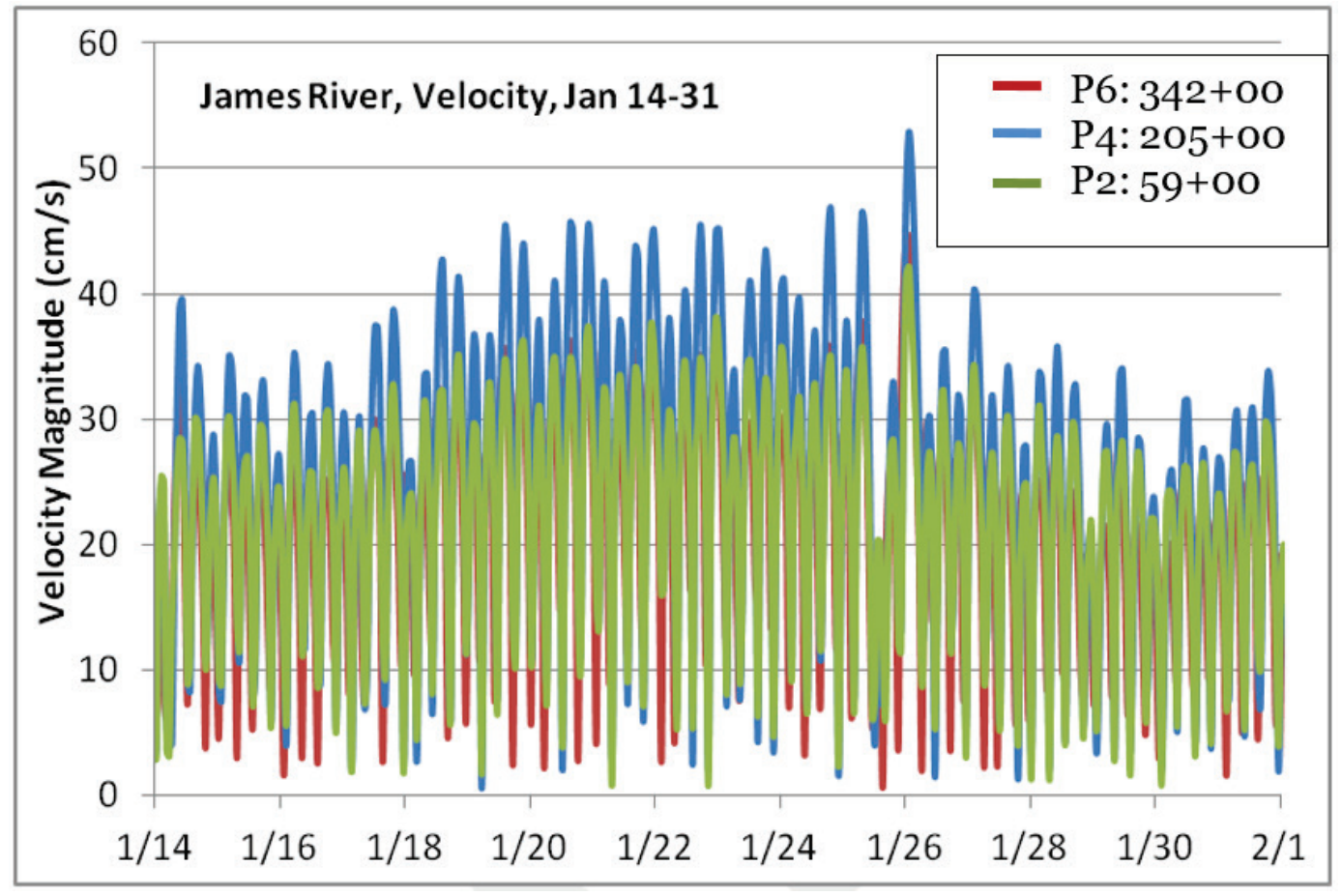

\subsubsection{Sediment characterization}

The PTM sediment source was characterized utilizing the source data described in Chapter 4. The sediment source was divided into three categories: clays, fine silts, and coarse silt. For each size class, a grain size distribution was determined (Table 5-2).

During the source term modeling, it was found that sand-sized particles deposited during placement and were unavailable for transport during the hydrodynamic period modeled. The transport of that sediment was then included in the LTFATE modeling described in Chapter 6.

The PTM source was introduced near the bed in the shape of an ellipsoid. The horizontal spread and vertical thickness are given in Table 4-5. The center point of the ellipsoid is given by the coordinates shown in Table 4-2. 
Table 5-2. PTM Source sediment grain size description.

\begin{tabular}{|l|c|c|}
\hline Sediment Type & D50 (microns) & Standard Deviation \\
\hline Clay & 1.3 & 0.35 \\
\hline File silt & 9.0 & 0.5 \\
\hline Coarse silt & 35.1 & 0.5 \\
\hline
\end{tabular}

\subsubsection{Settling rate and critical shear stress}

Sediments released into the water column during the dredging process are in one of three states: (1) primary particles, (2) bed aggregates, or (3) flocs. Primary particles are individual grains, usually sand or coarse silt, that are not bound with other particles. Bed aggregates are small fragments of the sediment bed that are suspended during the mechanical dredging process. These aggregates have a density of approximately $1.3 \mathrm{~g} / \mathrm{cm}^{3}$ as described in Chapter 3. Flocs are formed in the water column through cohesive particle collision. Floc aggregation rate is influenced by floc size, particle volume concentration, turbulent shear, and particle cohesion. Flocs are broken apart in the water column by particle collisions and internal shear. Representation of the flocculation process requires site-specific data and understanding of the natural system of interest. Lacking these data, bracketing of flocculation parameters was used to bound the potential effects of this process.

Particle settling is governed by the balance of gravity, buoyancy, and drag forces. These forces are determined by the fluid properties of density and viscosity and the particle properties of density, size, shape, and permeability. Extremely fine particles (e.g., non-flocculated clays) may stay in suspension for long periods of time and be transported much farther (as much as several orders of magnitude) than clay bound in bed aggregates and flocs. Therefore, fine-grained sediment settling rates and transport distances are strongly dependent upon the state of aggregation. A range of simulations were performed to bracket the settling rate.

PTM contains an internal theoretical calculation for the settling rate based on Soulsby (1997). Here the settling rate Ws (m/sec), is defined as a function of the dimensionless grain size $\mathrm{D}_{\mathrm{gr}}$, and can be approximated by the following equations proposed by Soulsby (1997). They have been adapted for extremely fine grain sizes $\left(D_{g r}<0.0672\right)$ for PTM. 


$$
\frac{W_{s} D}{v}=\left\{\begin{array}{c}
\sqrt{107.33+1.049 D_{g r}^{3}}-10.36, D_{g r} \geq 0.672 \\
0.0077 D_{g r}^{2}, D_{g r}<0.672
\end{array}\right.
$$

where

$$
D_{g r}=D_{50} \sqrt[3]{\frac{(s-1) g}{v^{2}}}
$$

Here, $\mathrm{D}_{50}$ is the grain size at which $50 \%$ of the sediment is finer by weight, $\mathrm{s}$ is the relative density $\rho_{\mathrm{s}} / \rho_{\mathrm{w}}$, and $v$ is the kinematic viscosity $\left(\mathrm{m}^{2} / \mathrm{sec}\right)$ of the fluid.

The minimum settling rate was initially calculated internally to the model using Equation 5-1, assuming that the clay particles were discrete instead of within flocs. Because of the properties of cohesive sediment, it is understood that this modeling was an extremely conservative treatment of clay particles that are generally not seen in the discrete particle form. More realistic characterization of clay particles is in the flocculated form. Simulations were run assuming the clay particles were in that state. A range of simulations was performed in which the settling rates were calculated based on the size of the flocs (assuming fine silt sized flocs). Finally, from previous communication and data from similar areas in the region *, a settling rate of $0.0003 \mathrm{~m} / \mathrm{s}$ was used for those particles. Overall, from multiple simulations, the clay settling rate ranged from approximately $1 \times 10^{-5} \mathrm{~m} / \mathrm{s}$ to $3.4 \times 10^{-4} \mathrm{~m} / \mathrm{s}$. Modeling results shown within this report applied the $3.4 \times 10^{-4} \mathrm{~m} / \mathrm{s}$ settling rate. Sensitivity analysis showed that both settling rates resulted in similar values on concentration and deposition. Silt particles settling rates were calculated internally to the model.

Data for critical shear stress were acquired based on previous work on the James River. Critical shear stress of deposition and initiation was assumed to be $0.1 \mathrm{~N} / \mathrm{m}^{2}$. Simulations were also performed using theoretically derived values calculated within the PTM model. Results showed very little difference between these two scenarios. Note that within Chapter 3 ,

\footnotetext{
* Dr. Jarrell Smith. Personal communication. Field Data Collection and Analysis Branch, Coastal and Hydraulics Laboratory, US Army Engineer Research and Development Center, Vicksburg, MS. June 2015.
} 
consolidated sediment at the placement site is described to have a critical shear stress of approximately $0.8 \mathrm{~N} / \mathrm{m}^{2}$. The sediment modeled within the PTM simulation is assumed to be transportable and initially available within the water column during placement. Therefore, the critical shear stress used for the PTM modeling is of primarily unconsolidated sediment. This sediment is therefore more accessible than the mound consolidated sediment described in Chapter 3.

\subsubsection{Source strength}

The mass rate of sediment introduced into the water column is determined by location. Table 4-5 gives the value for each location (Points 2,4 , and 6 ) modeled. Each sediment size class has its own mass rate.

\subsection{Computational parameters}

During modeling, additional parameters were required for computing diffusion and other processes that are required for transport (McDonald et al. 2006). Below in Table 5-3 is a list of the values used for the simulation. Values like the bed porosity, temperature, and salinity were site-specific parameters obtained from field data or the NOAA website.

Table 5-3. PTM Computational runtime parameters.

\begin{tabular}{|l|l|l|}
\hline PTM Parameter/Keyword & Description & Value \\
\hline :BED_POROSITY & Bed porosity & 0.8503 \\
\hline$:$ RHOS & Density of the bed sediments & 2642 \\
\hline$:$ MIN_DEPTH & Minimum computation depth in meters & 0.01 \\
\hline$:$ TEMPERATURE & Water temperature & 7.4 \\
\hline$:$ KET & Diffusion scalar & 0.25 \\
\hline$:$ KEW & Diffusion scalar & 0 \\
\hline$:$ KEV & Vertical diffusion coefficient & 0.00859 \\
\hline
\end{tabular}

\subsection{Analysis methods}

PTM analysis methods for this work include contour maps of suspended sediment concentration and sediment accumulation depths. The location of each particle is part of the natural PTM output. Suspended sediment concentration and the depth of accumulated sediment on the bed are calculated using a post-processing tool within the Surface-water Modeling System interface (Zundel 2000). A $30 \times 75$ cell Cartesian grid was 
developed (Figure 5-3) for Cartesian grid data set computations. Each grid cell is approximately $405 \times 287 \mathrm{~m}$. Computations for suspended sediment concentration and depth of deposited sediment were computed for each grid cell at every PTM output time-step (30 minutes).

Figure 5-3. PTM dataset analysis grid.

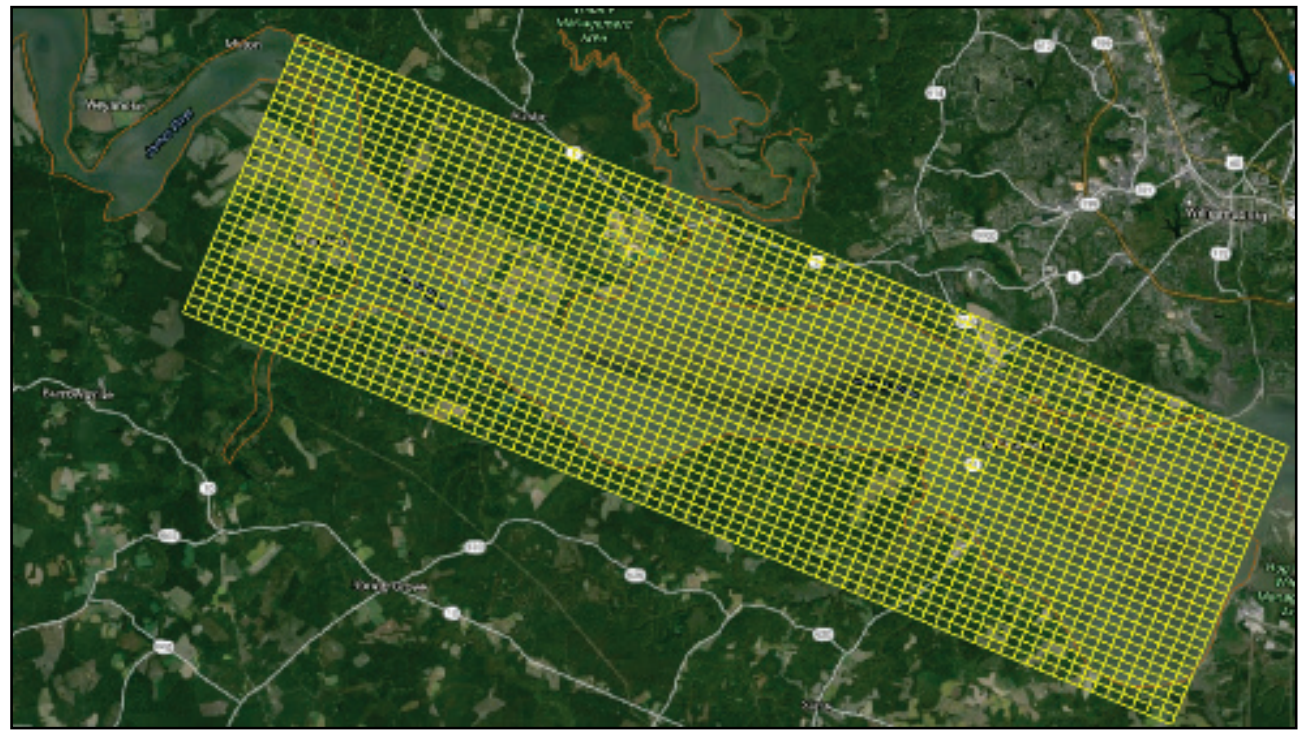

\subsubsection{Calculation of suspended sediment concentration}

The suspended sediment concentration (SSC) is determined per grid cell by determining the volume of water in the cell using the cell dimensions $(405 \times 287 \mathrm{~m})$ and the depth of water within that cell. The water depth is extracted from the hydrodynamic results described in Chapter 2. Each particle transported by PTM has an associated mass. The total mass of particles within the cell is calculated for each computational time-step. Note that multiple grids are developed and sensitivity analysis is performed to develop grid independent results. Grids vary in size to determine if the grid cell size impacts results.

$$
S S C=\frac{\sum \text { Parcel Mass }}{\text { Volume of Water }}
$$

\subsubsection{Calculation of depth of deposited sediment}

The volume of particles is calculated using the particle mass and density for particles that are located on the bed and in the cell. The volume in each cell is divided by the area of the cell to calculate an average depth in the cell. This gives a depth but does not include the void ratio $\left(\mathrm{H}_{\text {sediment }}\right)$. 
The percentage of the bed that is sediment as opposed to water is then calculated:

$$
x=\frac{\left(\rho_{\text {bed }}-1\right)}{\left(\rho_{\text {sediment }}-\rho_{\text {water }}\right)}=0.18
$$

The bed is therefore $18 \%$ sediment.

$$
\rho_{\text {sediment }} x 18 \%=.53 \mathrm{~g} / \mathrm{cm}^{\wedge} 3
$$

Deposited depth can therefore be calculated:

$$
\text { Deposited depth }(\mathrm{cm})=\frac{H_{\text {sediment }}(\mathrm{cm}) * \rho_{\text {sediment }}\left(\frac{\mathrm{g}}{\mathrm{cm}^{3}}\right)}{0.53\left(\frac{\mathrm{g}}{\mathrm{cm}^{3}}\right)}
$$

\subsection{Particle Tracking Model (PTM) results}

\subsubsection{Suspended sediment concentration}

Contour maps of suspended sediment concentration are shown in Figures 5-4 to 5-6 at initial source locations P2, P4, and P6, respectively. Results are shown after 1 day, 1 week, 2 weeks, and 1 month. Maximum concentration at each location is on the order of $100 \mathrm{mg} / \mathrm{L}$ for all locations. That concentration level only occurs at the immediate release point. In Figure 5-4 it can be seen that initially most of the suspended sediment remains in the placement area. After 2 weeks of dredging, sediment has been transported outside of the placement area in the downstream direction, although the simulation continues. By the end of the simulated month, most of the sediment has either deposited out of the water column or has been transported away. Maximum values outside of the immediate release site are less than $30 \mathrm{mg} / \mathrm{L}$.

For the central point $\mathrm{P} 4$, the maximum values at the release site are similar to the P2 location. However, the values outside of the immediate area show greater transport, which is consistent with the hydrodynamic results shown in the velocity time series (Figure 5-2). The footprint of the contour levels greater than $10 \mathrm{mg} / \mathrm{L}$ is spread farther. Relevant levels of suspended sediment concentration (greater than $5 \mathrm{mg} / \mathrm{L}$ ) still remain primarily within the placement site. By the end of the simulated month, the sediment is either deposited or no longer within the area of interest. 
The downstream point P6 shows the most transport away from the placement site. Suspended sediment concentrations from placed material remain less than $35 \mathrm{mg} / \mathrm{L}$ throughout the simulation.

\subsubsection{Accumulated depth}

Results of accumulated depth show maximum deposited sediment at the upstream point $\mathrm{P} 2$ to be approximately $0.50 \mathrm{~cm}$ (Figure 5-7). Note again that this is only for loss term (less than $5 \%$ of sediment that was initially discharged from the pipeline). The majority of the sediment (95\% of pumped material) immediately deposits in the placement area as part of the placement mound. The maximum loss term deposition depth values at $\mathrm{P} 2$ are greater than either $\mathrm{P} 4$ (Figure 5-8) or P6 (Figure 5-9). This is potentially because that area is within a deep bend in the river and is slightly sheltered by the geographical structure of the system. Deposited sediment released from point $\mathrm{P} 2$ appears to stay within the area throughout the simulation increasing with time as more sediment settles out of the water column.

Figure 5-8 shows an interesting pattern of placement at location P-4. The sediment is spread over a much larger area than $\mathrm{P}-2$, so the maximum deposition depth is less than $0.20 \mathrm{~cm}$. It is also possible to see areas of the placement site where deposition is more likely to occur. Initially, sediment accumulates in two separate discrete zones. Within 2 weeks, as more sediment is released and transport occurs with time, the zones connect, but from this visualization it is possible to get a better understanding of how deposition occurs at the placement site and which areas are more likely to retain sediment during placement. Figure 5-9 (P6) shows similar trends to Figure 5-8, though overall there is less sediment that remains in the placement area. Maximum values of accumulated sediment are less than $0.1 \mathrm{~cm}$ for the P6 release point scenario. For this point, most of the sediment is transported away from the placement area farther downstream. 
Figure 5-4. Suspended sediment concentration at P2 after (A) 1 day, (B) 1 week, (C) 2 weeks, and (D) 1 month.

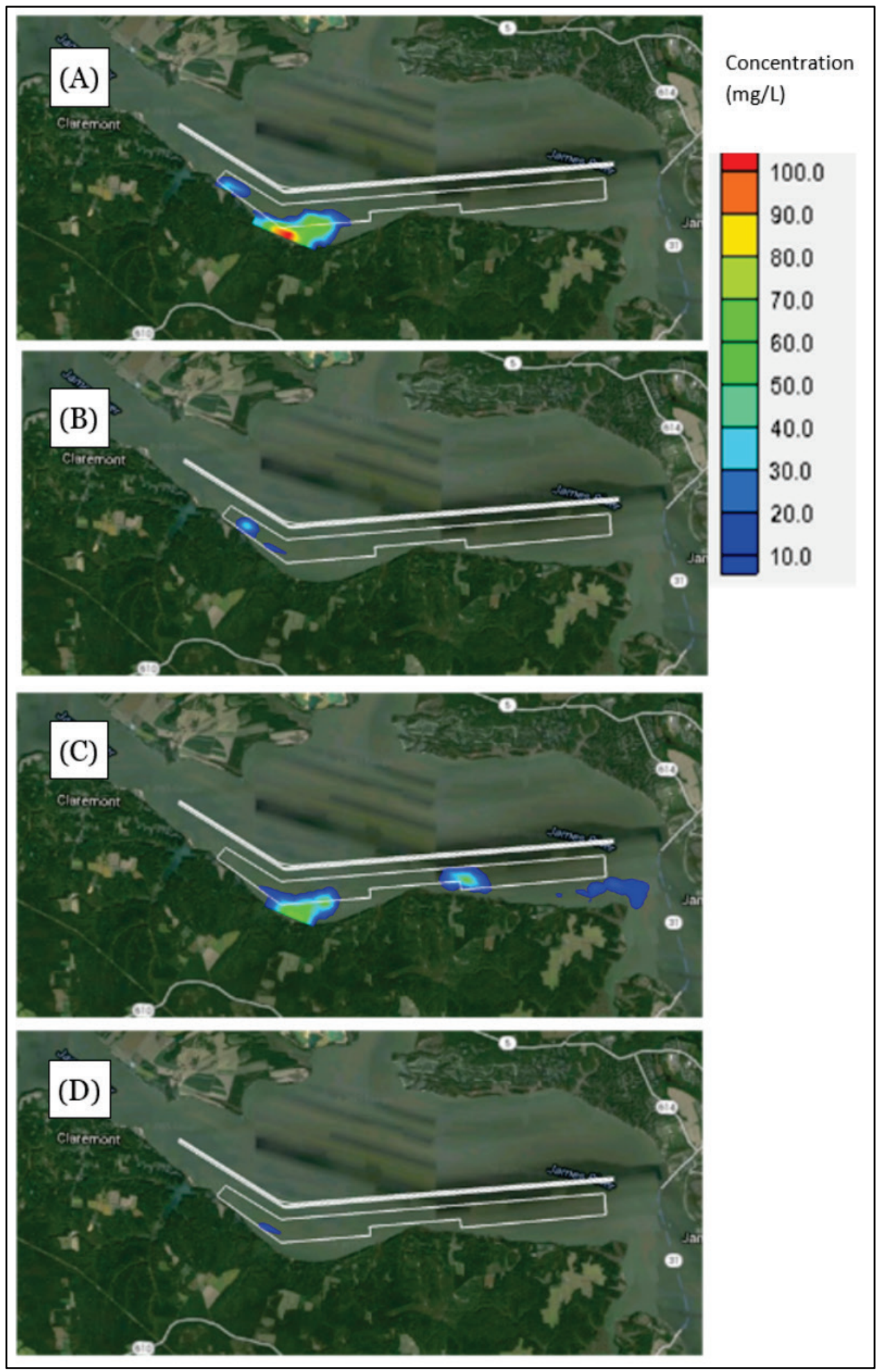


Figure 5-5. Suspended sediment concentration at P4 after (A) 1 day, (B) 1 week, (C) 2 weeks, and (D) 1 month.

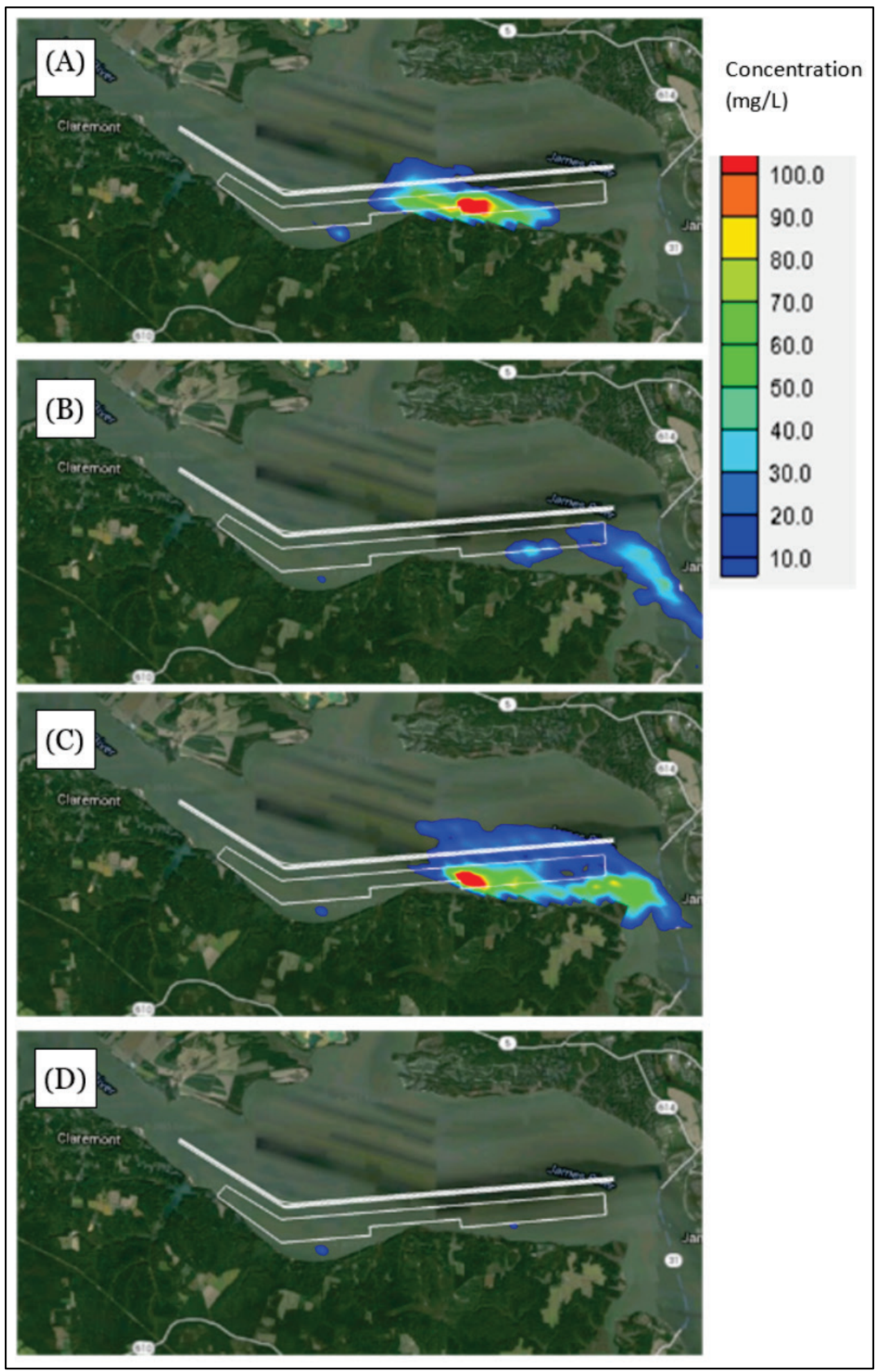


Figure 5-6. Suspended sediment concentration at P6 after (A) 1 day, (B) 1 week, (C) 2 weeks, and (D) 1 month.

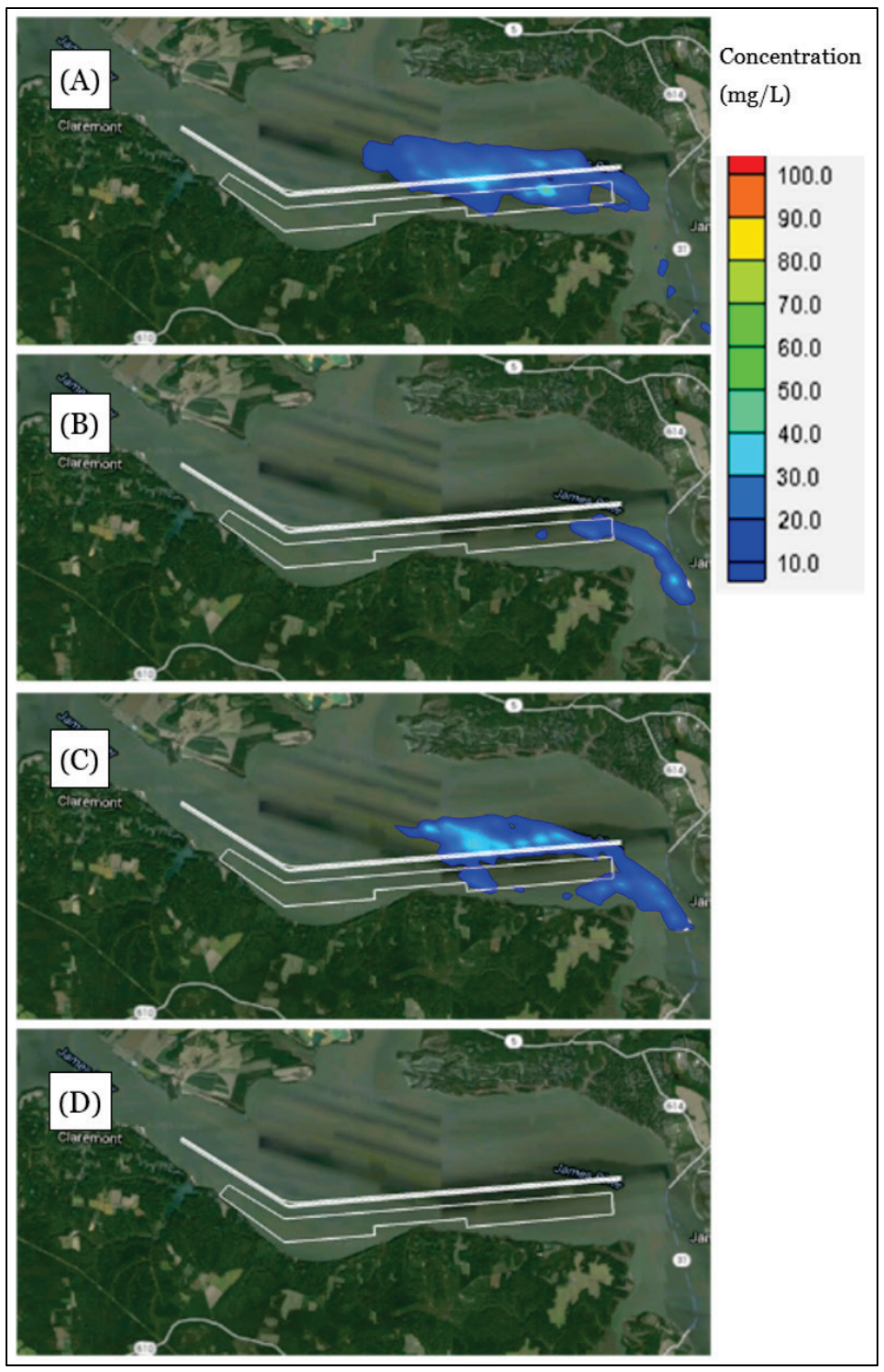


Figure 5-7. Deposition depth at P2 after after (A) 1 day, (B) 1 week, (C) 2 weeks, and (D) 1 month.

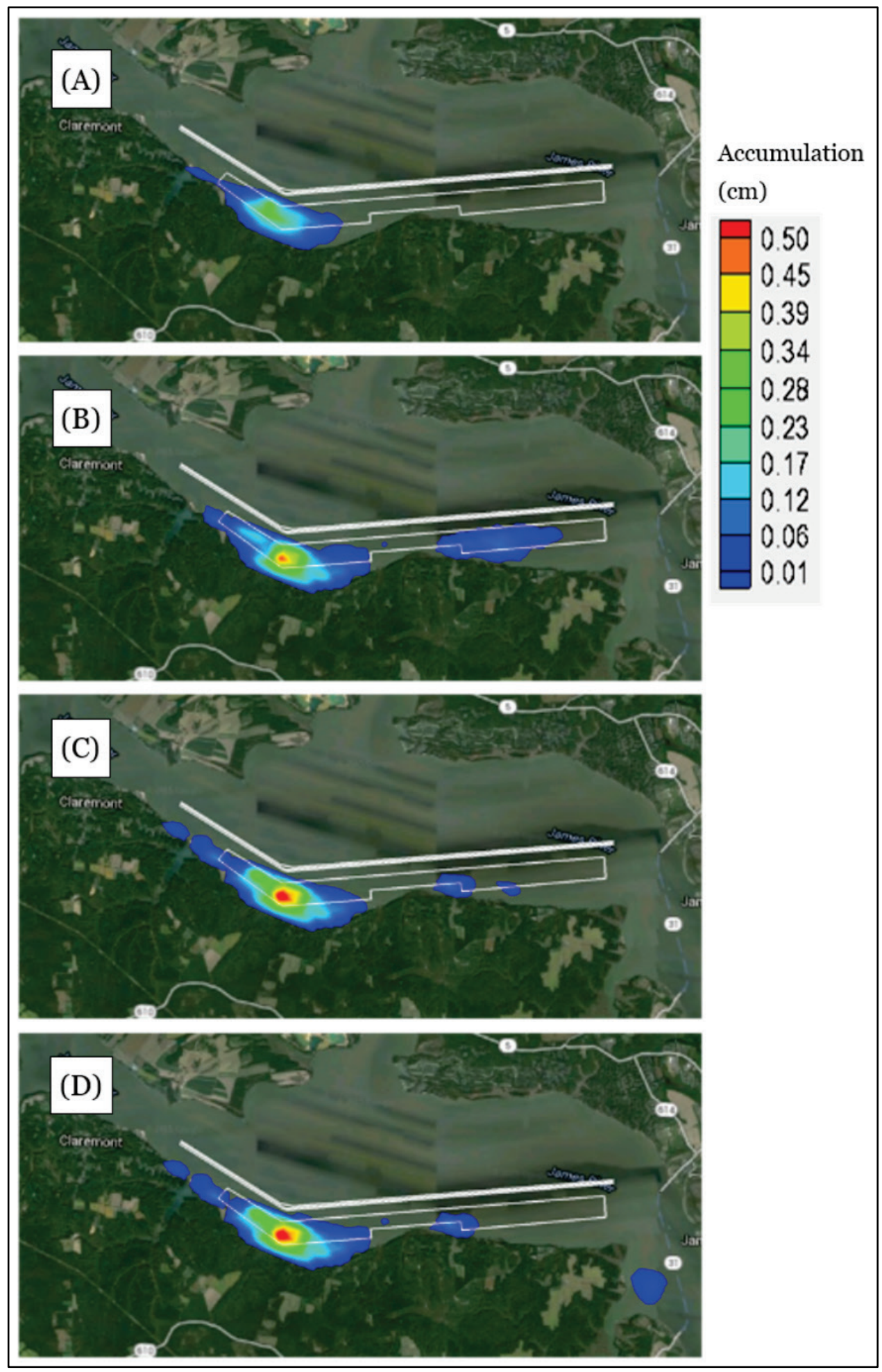


Figure 5-8. Deposition depth at P4 after after (A) 1 day, (B) 1 week, (C) 2 weeks, and (D) 1 month.

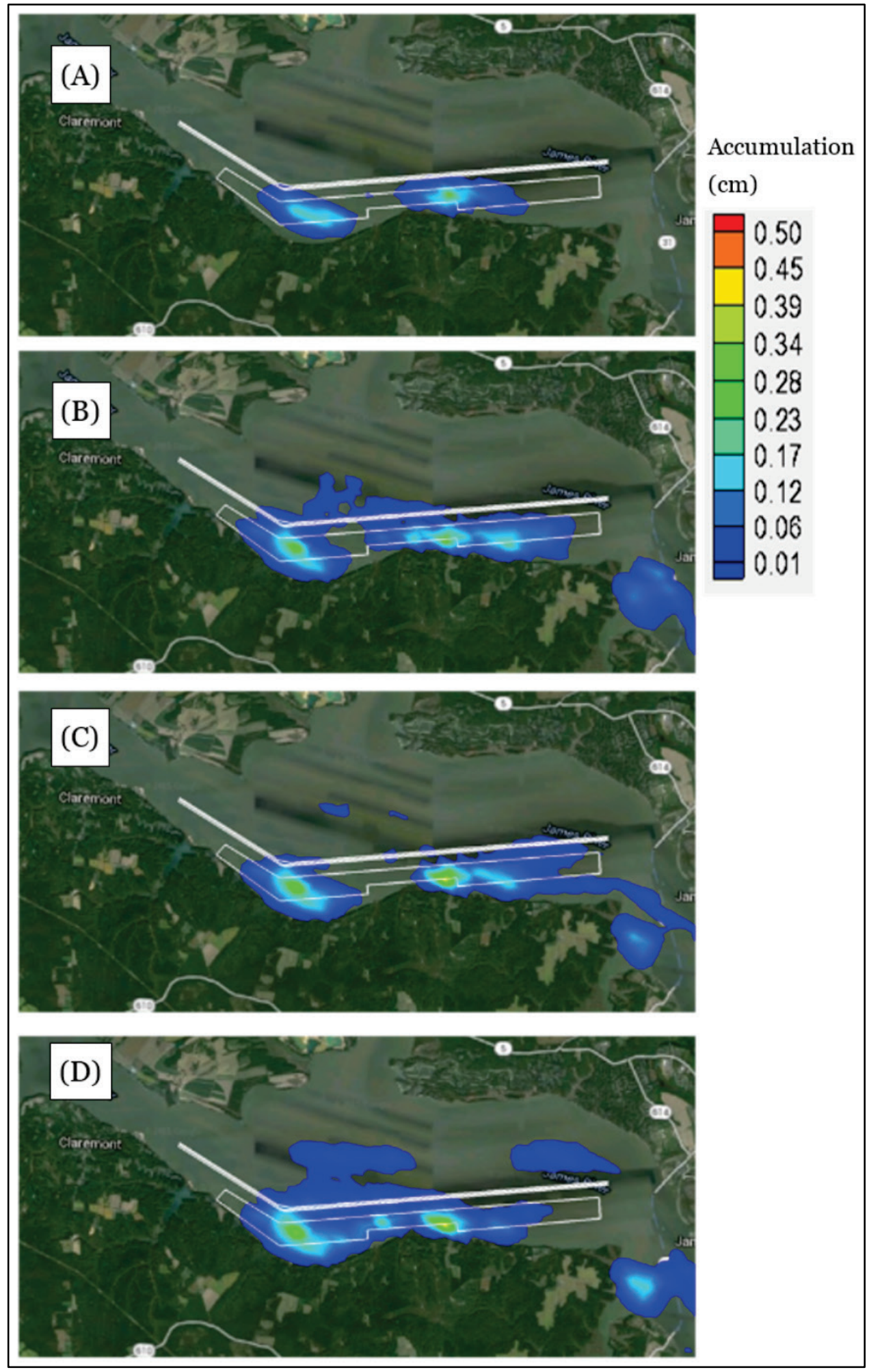


Figure 5-9. Deposition depth at P6 after after (A) 1 day, (B) 1 week, (C) 2 weeks, and (D) 1 month.

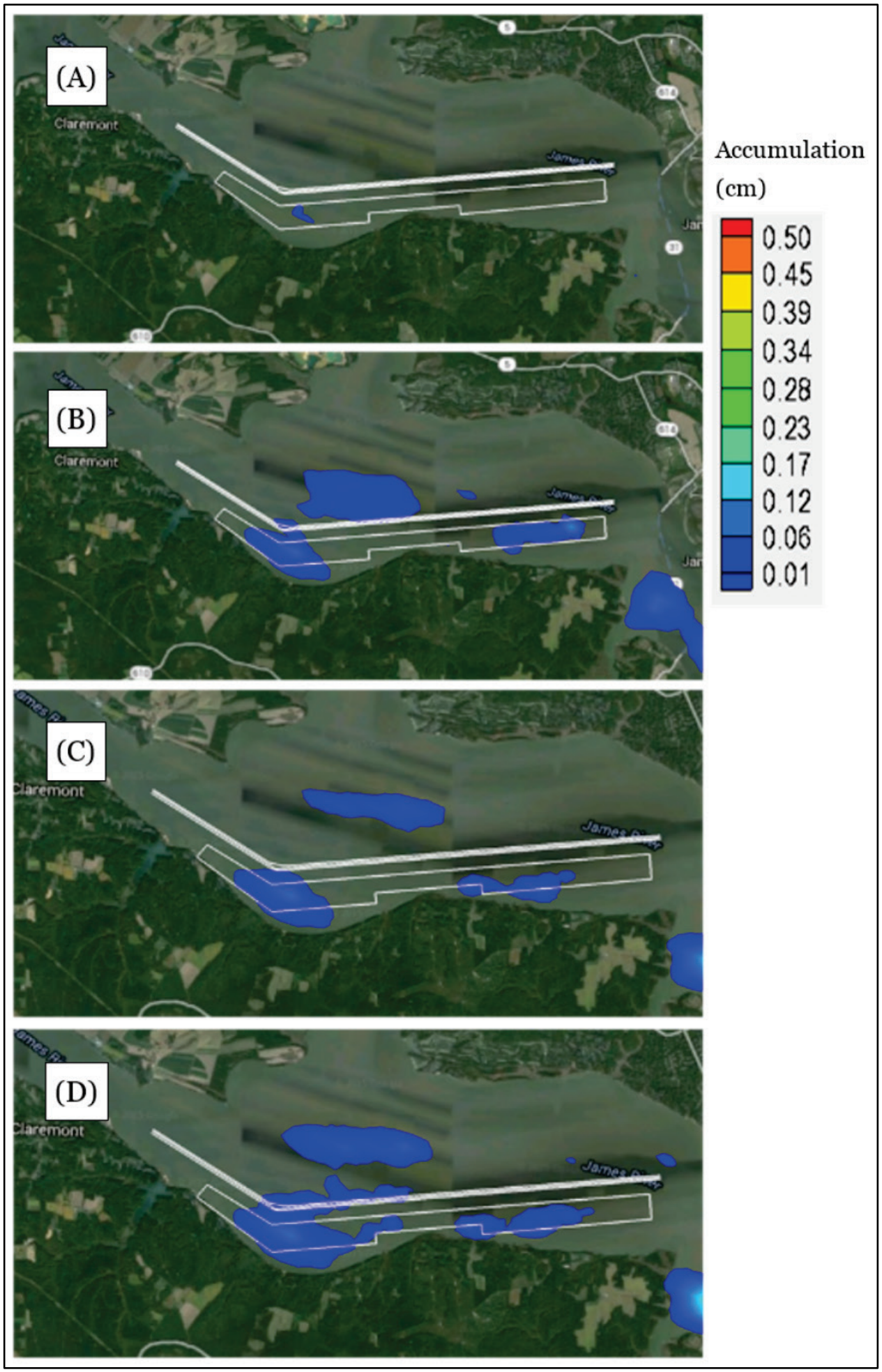




\subsection{Conclusions}

The fate of sediment resuspended during placement of dredged material in James River placement site (Dancing Point-Swann Point) was modeled for 1 month using the PTM. For the simulations, placement occurred during the first 17 days. The transport of the material was modeled for an additional 2 weeks after dredging was completed to determine ultimate fate.

Three locations were chosen as pipeline placement release points, which, as a whole, encompass the entire dredge placement site. It was found that sediment placed on the upstream end tended to deposit and remain near the placement site. The maximum depth of deposited material $(0.50 \mathrm{~cm})$ occurred in that scenario. The largest predicted mass rate of material released to the water column was from the release point near the middle of the placement site. The footprint of deposited material was the most extensive for that case. Model results indicate that the least amount of deposited material was from the downstream release point. In comparison to the other two release points, more sediment is transported away from the area of interest for that scenario.

The maximum suspended sediment concentration for all cases was on the order of $100 \mathrm{mg} / \mathrm{L}$. However, in areas outside of the placement site, suspended sediment concentration values were less than $40 \mathrm{mg} / \mathrm{L}$. These values are relatively modest in comparison to background suspended sediment for this area, which can range from $5 \mathrm{mg} / \mathrm{L}$ to $300 \mathrm{mg} / \mathrm{L}$, depending on the meteorological and hydrodynamic conditions.

Results suggest that the material released into the water column remains in the placement area or is transported out of the area of interest downstream. These types of exposure results can ultimately be paired with effects data to understand the risk to local environmental receptors such as oyster reefs or other species. Results show some sediment pathways back towards the channel and that some of the material modeled does accumulate within the channel; however, understanding the true migration of the entire mound requires an Eulerian modeling method such as that shown in Chapter 6. 


\section{Morphology and Overall Mound Transport (LTFATE Modeling)}

\subsection{LTFATE based on SEDZLJ}

To investigate the fate of sediments and morphology change from the dredged material mound, the MB LTFATE model was applied (Hayter et al. 2012). LTFATE sediment transport computations are performed in conjunction with hydrodynamics on the same MB grids as described in Chapter 2.

The SEDZLJ sediment transport module in LTFATE includes both bedload and suspended load transport. For bedload transport, Van Rijn's (1984) approach is used, and 2D mass balance for the bedload concentration is solved to give bedload flux. For suspended load transport, 3D advectivedispersive transport equation for each of sediment size classes is solved, in which settling velocities of non-cohesive sediments are given by Cheng's formula (Cheng 1997) and those of cohesive sediments are set as inputs. In SEDZLJ, bed processes include erosion and deposition. Erosion parameterization is determined from SEDFLUME experiments (Chapter 3). The bed processes also include bed armoring by coarser sediment classes. SEDZLJ imposes multiple bed layers including an active layer. The bed model also has algorithms for consolidation of bed that influence bed bulk density and the bed critical shear stress. An empiricalbased consolidation algorithm is included in SEDZLJ. Simulation of consolidation requires performing specialized consolidation experiments to quantify the rate of consolidation as described in Chapter 3 .

One of the first steps in performing sediment transport modeling is to use grain size distribution data from sediment samples collected at different locations throughout the model domain to determine how many discrete sediment size classes are needed to adequately represent the full range of sediment sizes. Typically, three to eight size classes are used. For example, for the current modeling study, two size classes are used to represent sediment in the cohesive sediment size range, and three size classes are used to represent the noncohesive sediment size range. The classes are further divided into two sets-one for dredged sediments in the mound and the other for existing bed sediments-so that the model deals with 10 size classes. Each sediment size class is represented in LTFATE using the median or mean diameter within that size range. LTFATE sediment bed is 
initialized by sediment class distribution in each layer of each cell in the model. For application at the James River, one of five core types was assigned to each cell. Core 1 represents the mound (grain size distribution data described in Chapter 3), core 2 represents shoal, core 3 represents navigation channel, and core 4 represents non-cohesive sediment dominant entrance channel bed. Core 5 represents the non-erodible bed away from the study area. Figure 6-1 shows the distribution of cores in the James River grid for the section from Swann - Dancing Point.

Figure 6-1. Distribution map for core types.

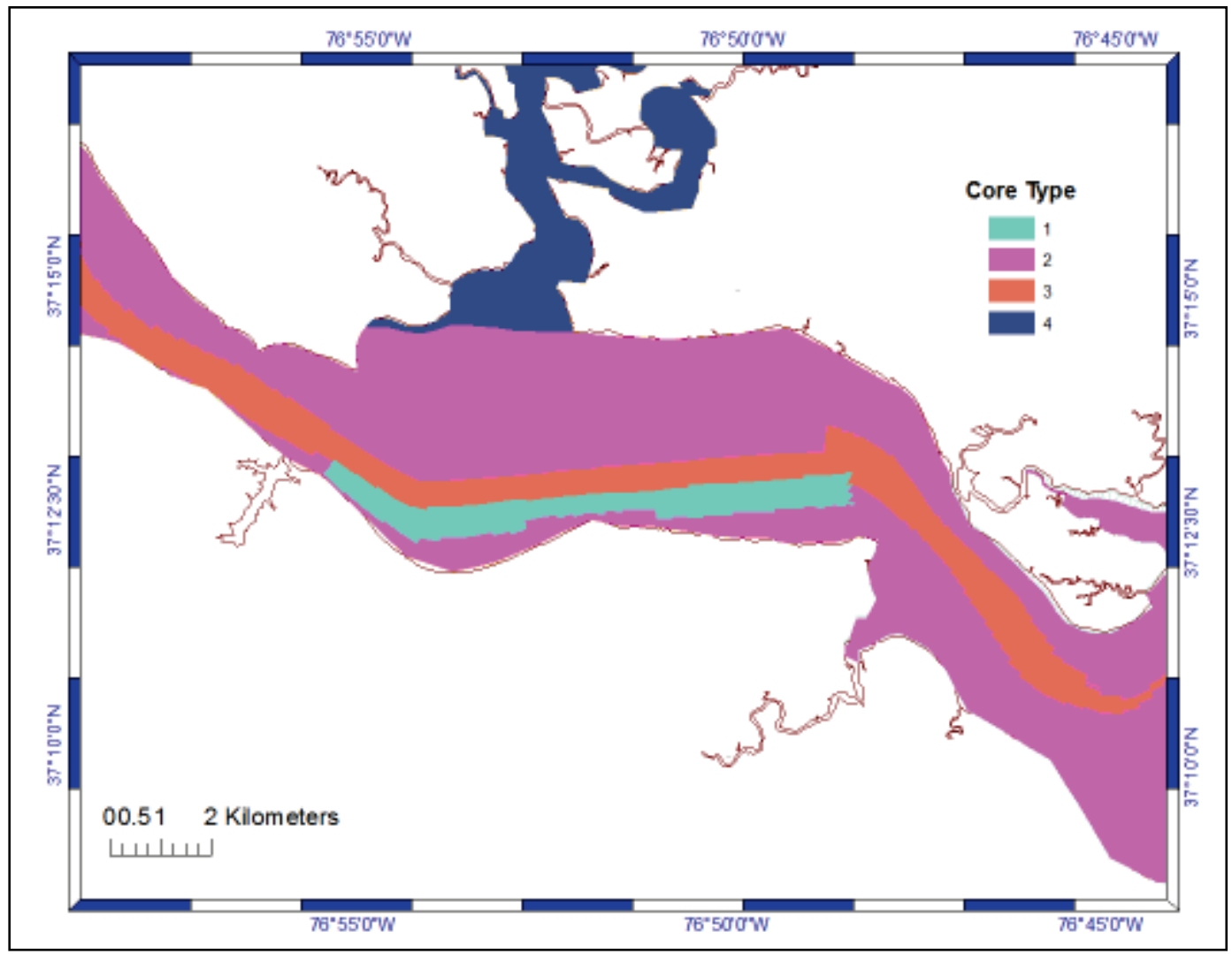

Table 6-1 lists the 10 sediment size classes and additional non-erodible class with properties including particle diameter, $\mathrm{D},(\mu \mathrm{m})$; settling velocity, $\mathrm{wfs}_{\mathrm{fs}},(\mathrm{mm} / \mathrm{s})$; and critical shear stresses for deposition, $\tau$ crd, and for erosion, $\tau$ cre, $\left(\right.$ dynes $\left./ \mathrm{cm}^{2}\right)$. The table also shows percentages of size classes for different core types. 
Table 6-1. Setup bed sediment characteristics.

\begin{tabular}{|l|c|c|c|c|c|c|c|c|c|c|c|}
\hline & C1 & C2 & C3 & C4 & NC1 & NC2 & NC3 & NC4 & NC5 & NC6 & UN \\
\hline $\mathrm{D}$ & 20 & 20 & 20 & 20 & 30 & 100 & 300 & 30 & 100 & 300 & 4000 \\
\hline $\mathrm{W}_{\mathrm{fs}}$ & 0.3 & 0.7 & 0.3 & 0.7 & & & & & & & \\
\hline $\mathrm{T}_{\text {crd }}$ & 1.0 & 2.0 & 1.0 & 2.0 & 0.85 & 1.16 & 2.87 & 0.85 & 1.16 & 2.87 & 98.9 \\
\hline$T_{\text {cre }}$ & 1.0 & 2.0 & 1.0 & 2.0 & 0.85 & 0.71 & 2.03 & 0.85 & 0.71 & 2.03 & 30.8 \\
\hline Core 1 & 0 & 0 & 8 & 5 & 75 & 7 & 5 & 0 & 0 & 0 & 0 \\
\hline Core 2 & 25 & 25 & 0 & 0 & 0 & 0 & 0 & 40 & 5 & 5 & 0 \\
\hline Core 3 & 15 & 15 & 0 & 0 & 0 & 0 & 0 & 30 & 30 & 10 & 0 \\
\hline Core 4 & 0 & 0 & 0 & 0 & 0 & 0 & 0 & 10 & 40 & 50 & 0 \\
\hline Core 5 & 0 & 0 & 0 & 0 & 0 & 0 & 0 & 0 & 0 & 0 & 100 \\
\hline
\end{tabular}

The sediment transport model is a part of the hydrodynamic model. The first 3 months of hydrodynamic model simulation were treated as spin up for the sediment transport model. Sediment transport simulation for the following 6 months between April and September of 2000 were run with SEDZLJ module in LTFATE. River discharge was an input to the hydrodynamic data. However, no data were available to quantify upstream sediment loadings. Therefore, upstream load was not included in the SEDZLJ model. This reduced channel infilling in the model because upstream is a major source of channel sediments. However, the scope of this study was not to quantify channel infilling due to upstream loadings but rather to quantify the amount of dredged material from the mound that re-enters the channel. Consequently, results shown herein are not total sedimentation but rather just sedimentation induced by dredging operation and local resuspension.

\subsection{Simulation results}

Figure 6-2 shows the focus area for post-processing of the simulations.

Figure 6-3 shows the relationships between hydrodynamics and bed evolution. The dredged material mound experiences deposition during the 3 -month simulation. The accretion over the mound is gradual for the first month or so and then reaches a quasi-steady state. The source of sediment to the mound is the upstream bed. The channel also has accretion over time, but the magnitude is much smaller compared to the mound. The channel appears more responsive to the hydrodynamic conditions. Around 8 April, a small event causes erosion in the channel. Then a big freshet 
event occurs around 20 April; the channel starts to accrete sediment with sediment eroded from the bed upstream of this section of the channel.

Figure 6-2. Location of navigation channel (red) and placement mound (marked by blue line) on computational grid blocks 1 (green), 2 (orange), and 3 (cyan).

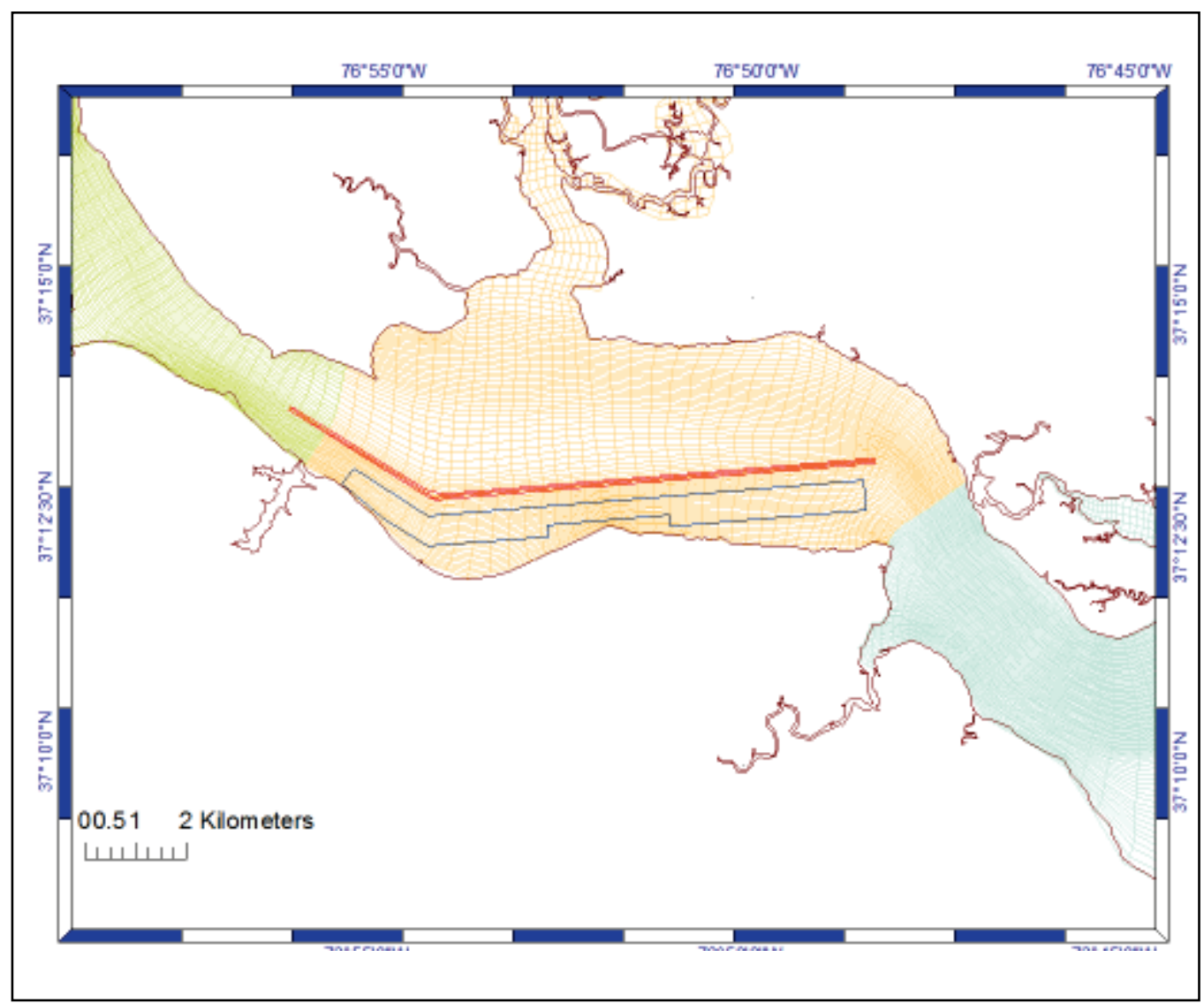


Figure 6-3. Hydrodynamics and bed evolution-from top to bottom (a) freshwater discharge from James River, (b) simulated water levels in the navigation channel, (c) magnitude of mean bottom velocities in the channel, and (d) mean bed elevation deviations from initial bed at the mound (red) and the channel (blue).

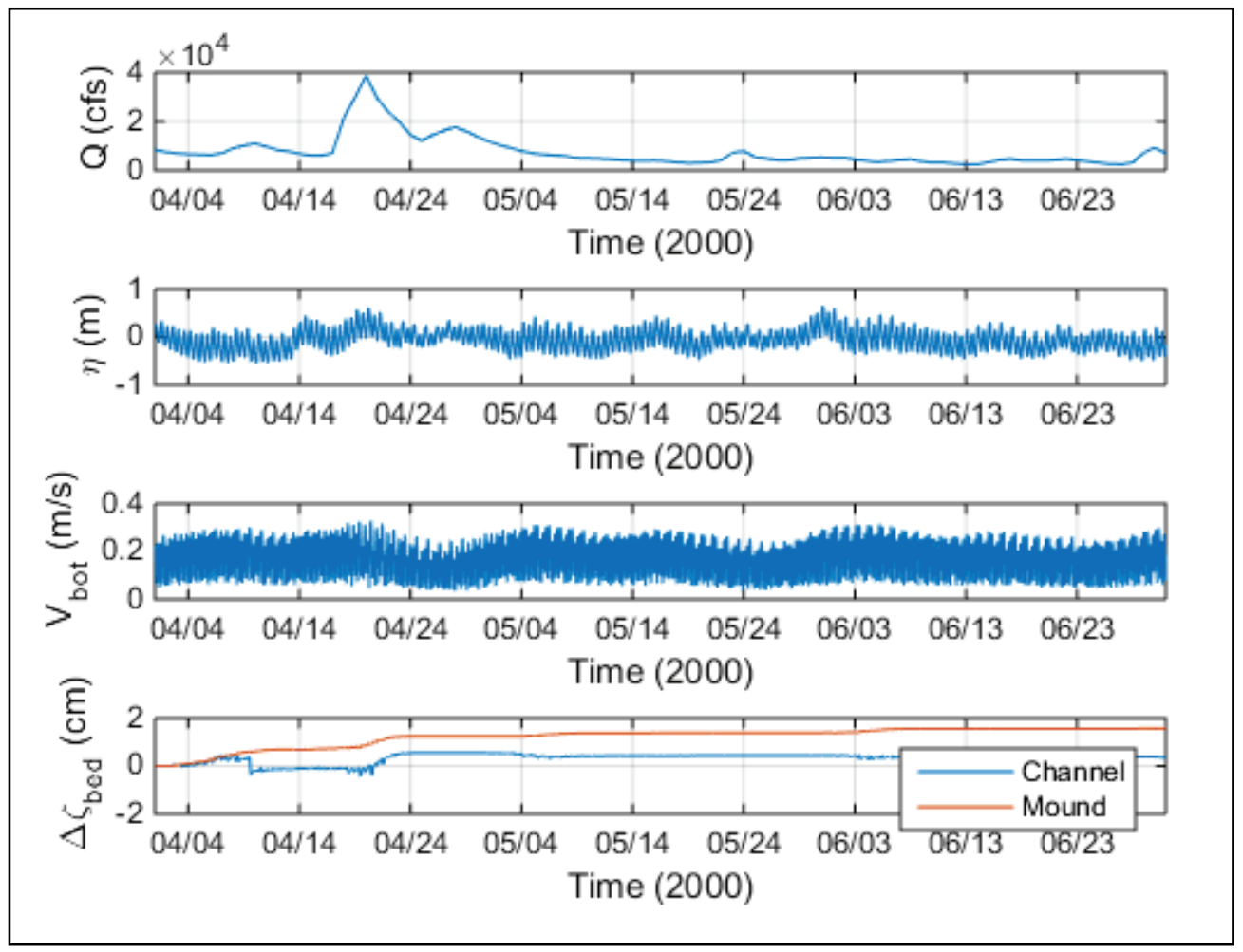

Suspended sediment concentration primarily responds to resuspension from the bed and advection-diffusion in water column. The temporalspatial distribution of suspended sediment concentration varies with tidal phase. Figure 6-4 to Figure 6-6 show suspended sediment variation over different tidal phases. Figure 6-7 to Figure 6-9 show variations during the same flood cycle for bedload. Figure 6-10 to Figure 6-15 show variations during the following ebb cycle. Suspended sediment concentrations are dispersive while bedload concentrations are intermittent. These results are consistent because suspended sediment concentration behaves as a passive matter in a water column subject to diffusion and bedload transport is a function of instantaneous bed stress and bed slope relative to adjacent grid cells.

Model predictions indicate significant sediment erosion and transport occur both upstream and downstream of the channel but not much in the area of the channel and mound. The higher concentrations coincide with stronger current. It is notable that the higher concentrations are near the channel and not over the shoals. Figures 6-16 and 6-17 show bed elevation 
changes during flood and ebb, respectively. Bed changes are a slow process, and it is difficult to observe distinct pattern change over different tidal phases because bed changes are cumulative results.

Figure 6-4. Bottom suspended sediment concentration $\left(\mathrm{g} / \mathrm{cm}^{3}\right)$ during flood at $4 / 8$ 03:00 and 4/8 04:00.

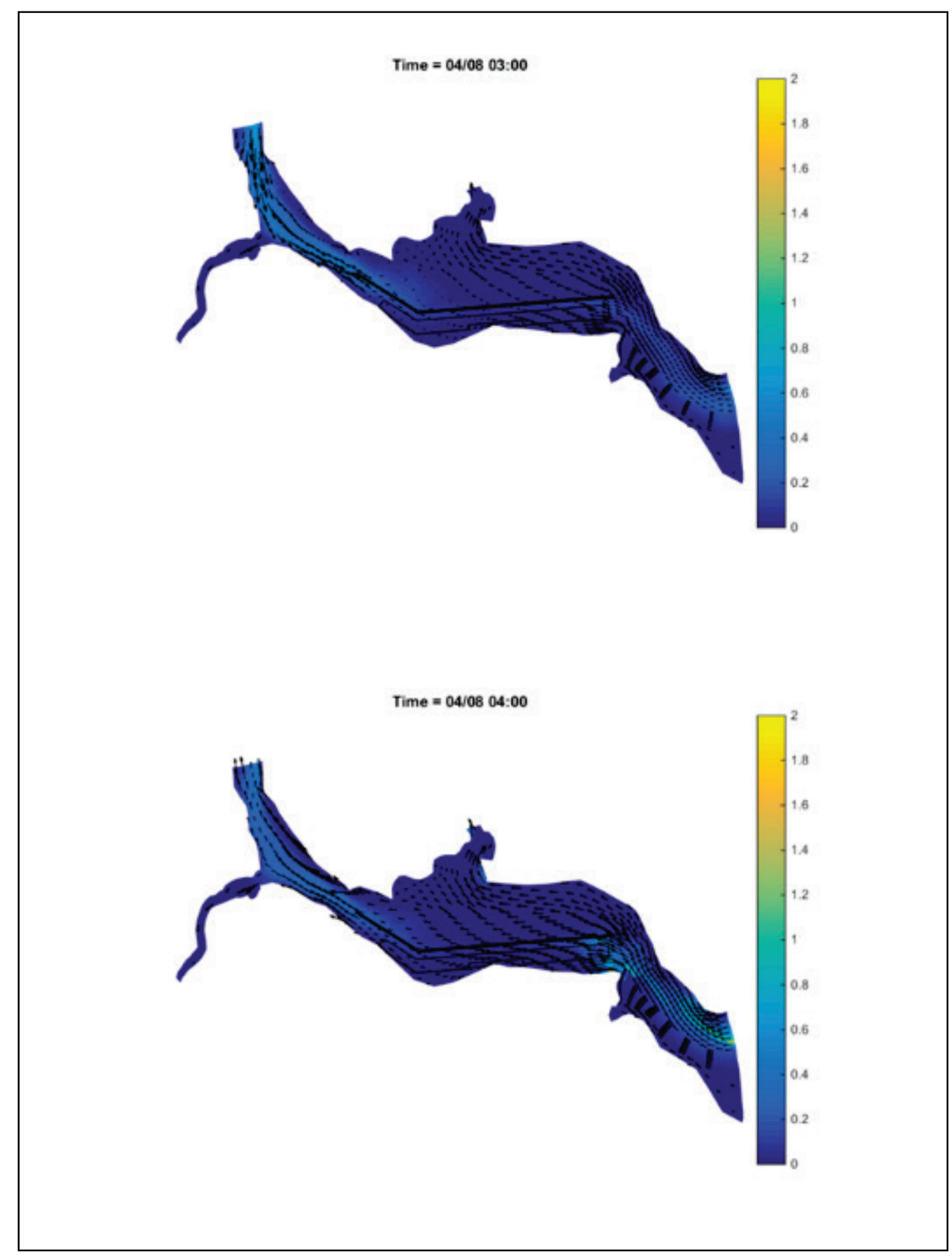


Figure 6-5. Bottom suspended sediment concentration $\left(\mathrm{g} / \mathrm{cm}^{3}\right)$ during flood at $4 / 8$ 05:00 and 4/8 06:00.

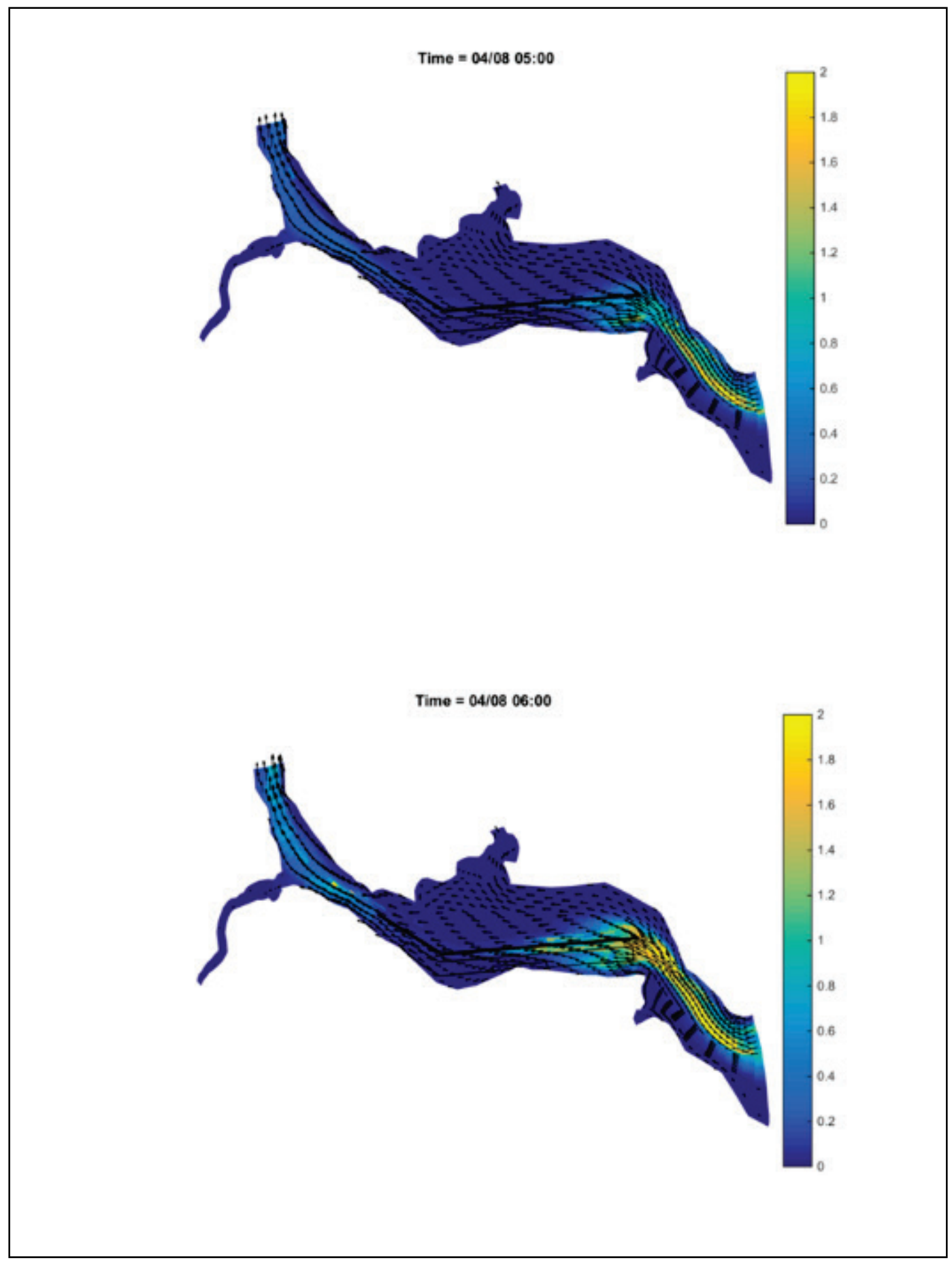


Figure 6-6. Bottom suspended sediment concentration $\left(\mathrm{g} / \mathrm{cm}^{3}\right)$ during flood at $4 / 8$ 07:00 and 4/8 08:00.

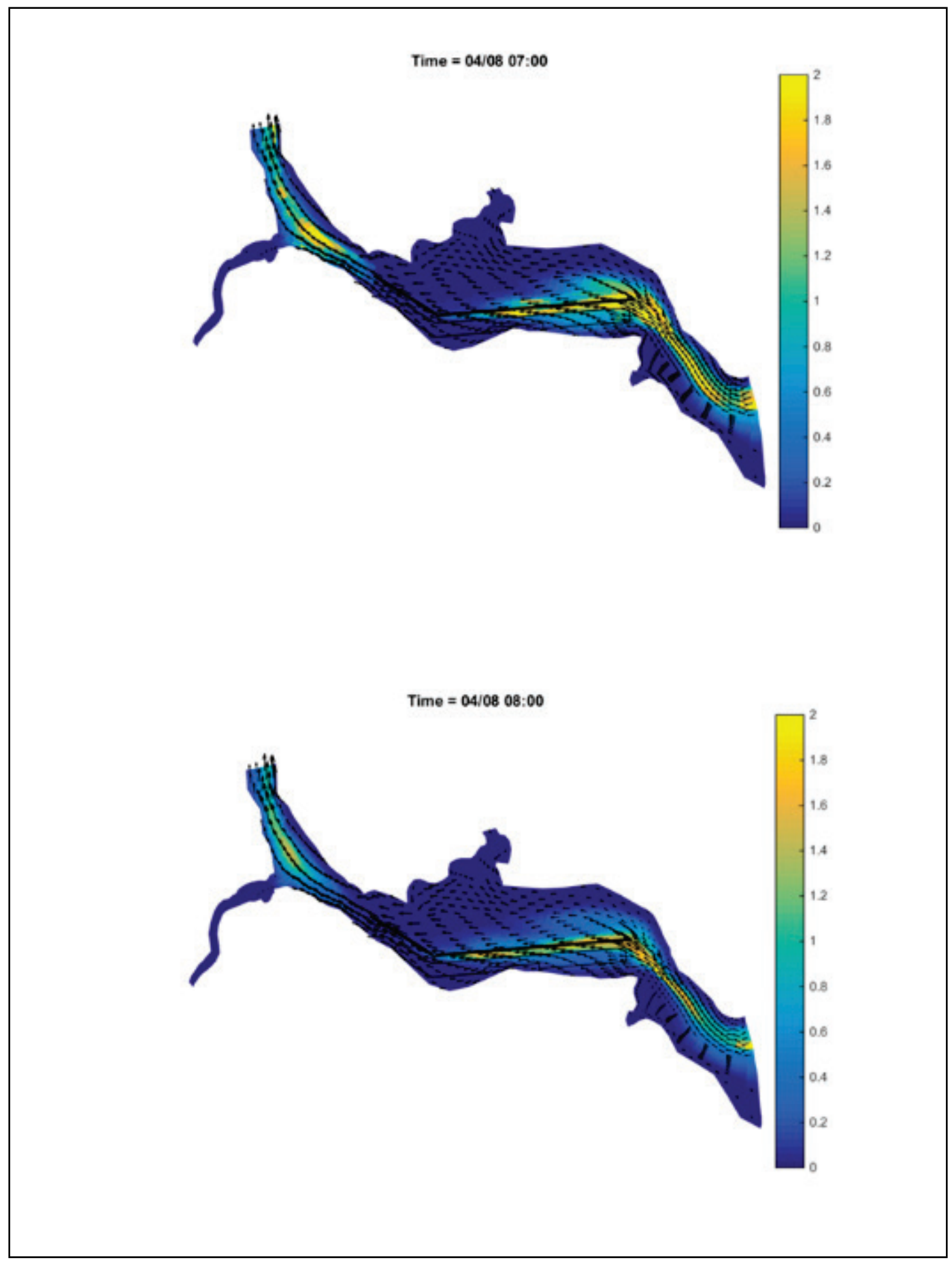


Figure 6-7. Bedload concentration $\left(\mathrm{g} / \mathrm{cm}^{3}\right)$ during flood at 4/8 03:00 and 4/8 04:00.

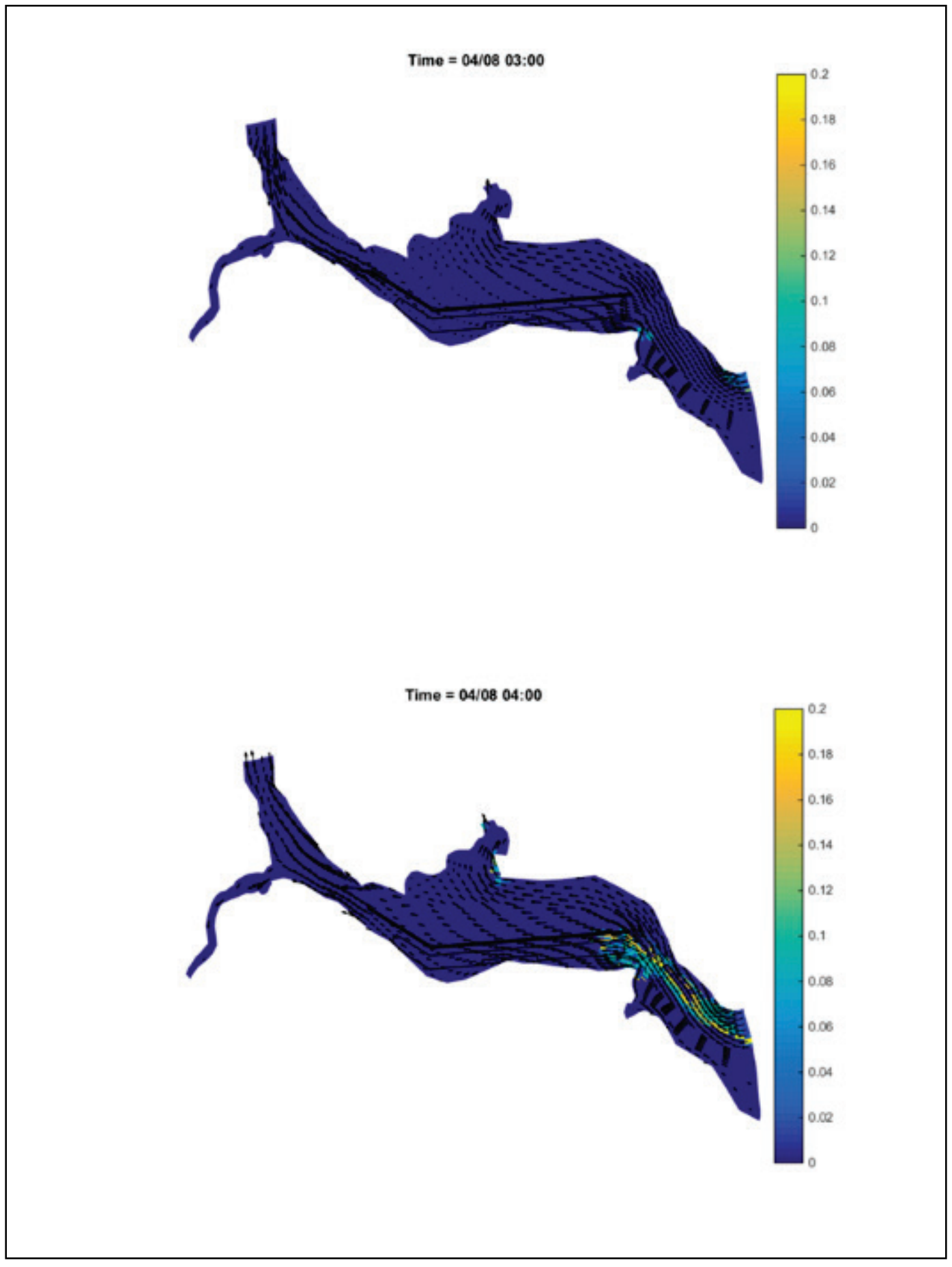


Figure 6-8. Bedload concentration $\left(\mathrm{g} / \mathrm{cm}^{3}\right)$ during flood at 4/8 05:00 and 4/8 06:00.

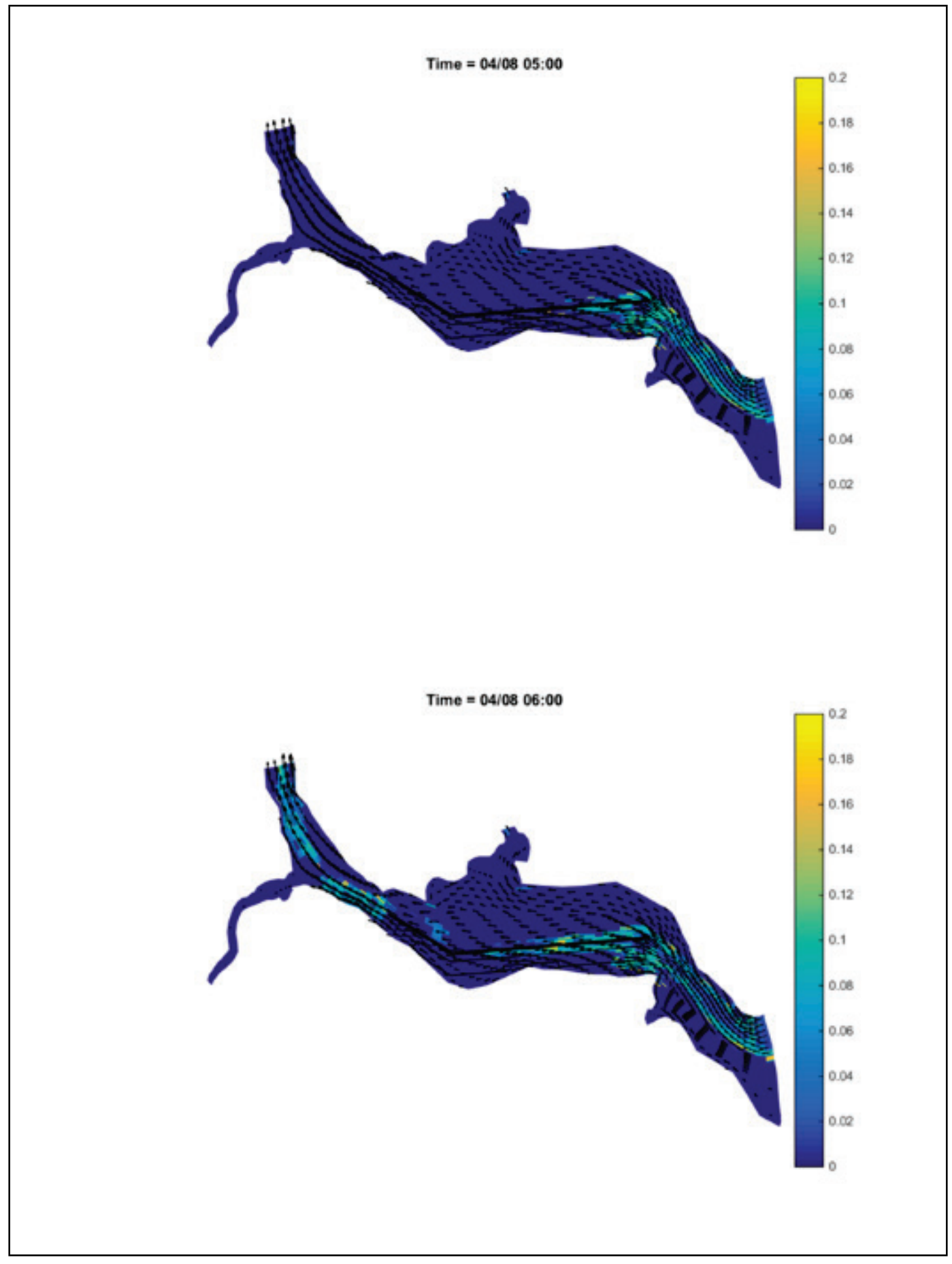


Figure 6-9. Bedload concentration $\left(\mathrm{g} / \mathrm{cm}^{3}\right)$ during flood at 4/8 07:00 and 4/8 08:00.

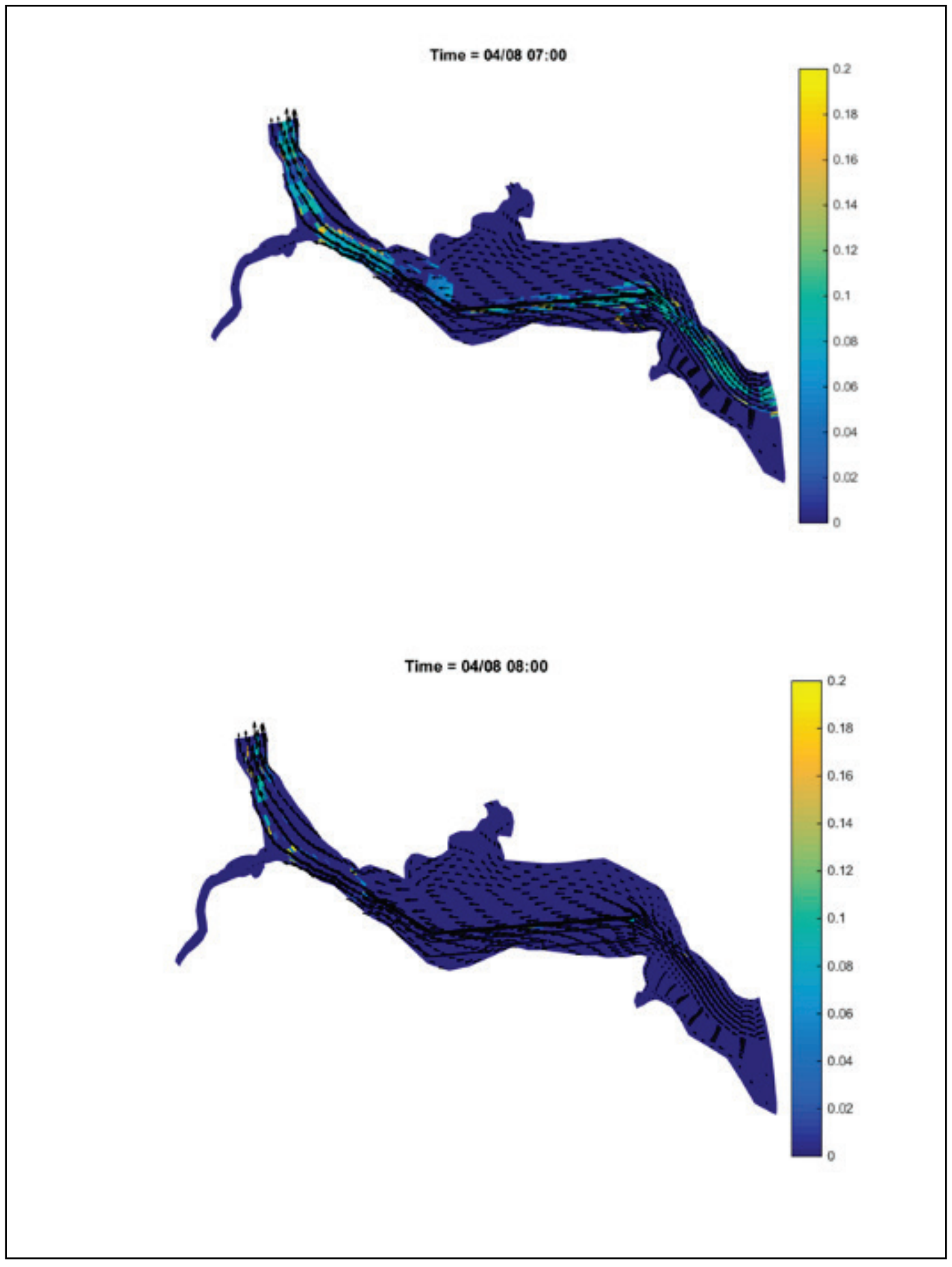


Figure 6-10. Bottom suspended sediment concentration $\left(\mathrm{g} / \mathrm{cm}^{3}\right)$ during ebb at $4 / 8$ 05:00 and 4/8 06:00.

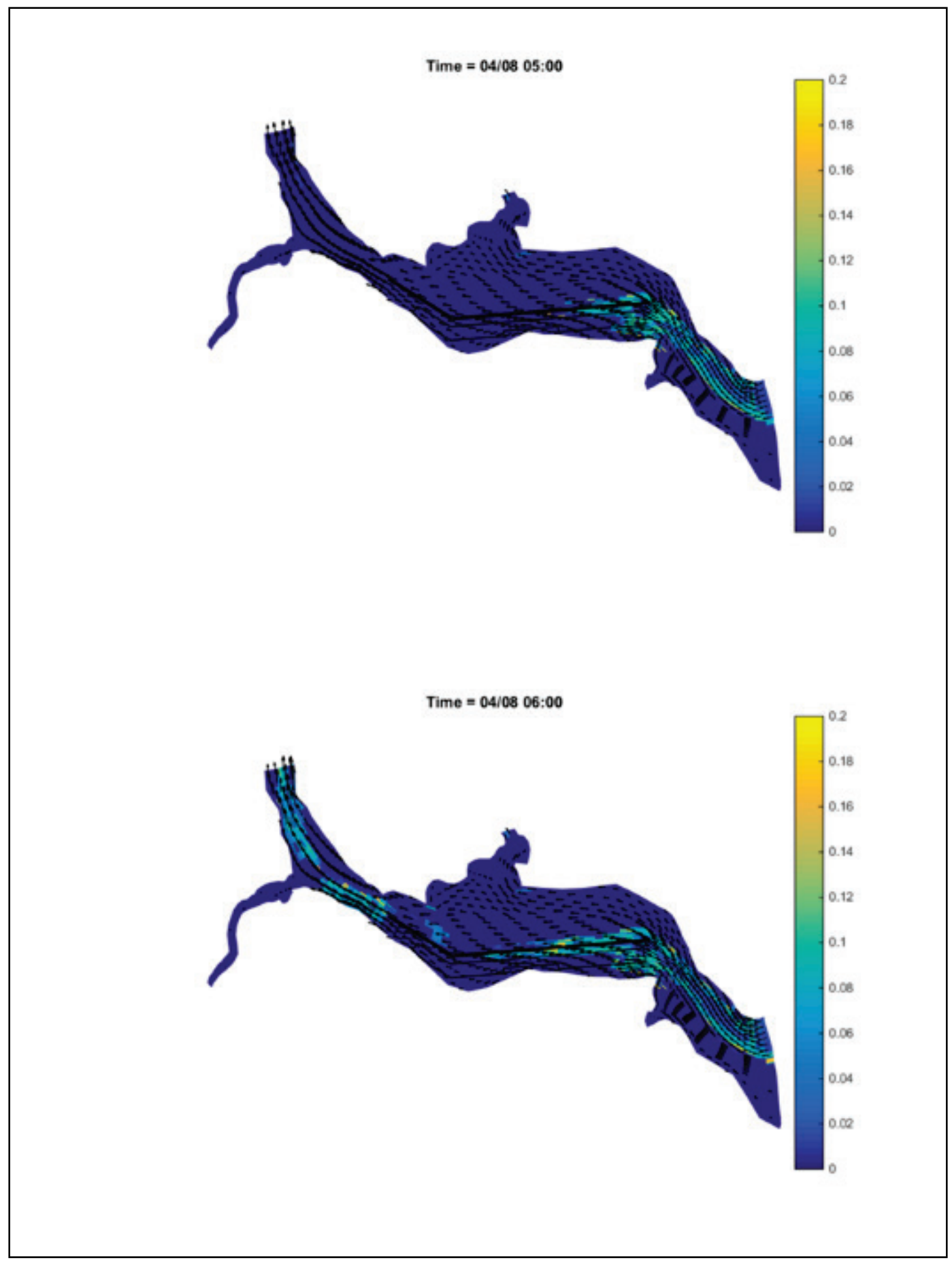


Figure 6-11. Bottom suspended sediment concentration $\left(\mathrm{g} / \mathrm{cm}^{3}\right)$ during ebb at $4 / 8$ 12:00 and 4/8 13:00.

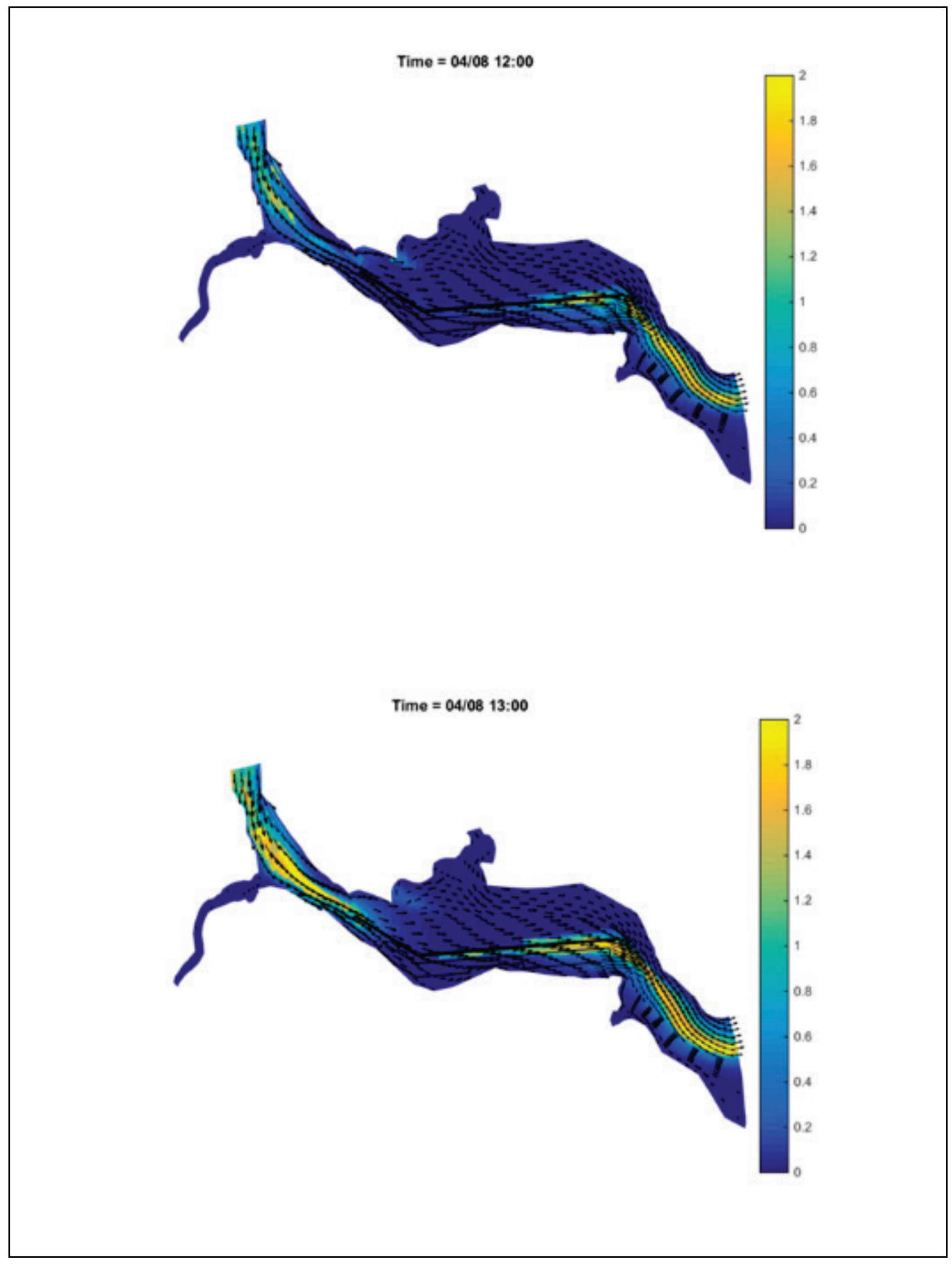


Figure 6-12. Bottom suspended sediment concentration $\left(\mathrm{g} / \mathrm{cm}^{3}\right)$ during ebb at $4 / 8$ 14:00 and 4/8 15:00.

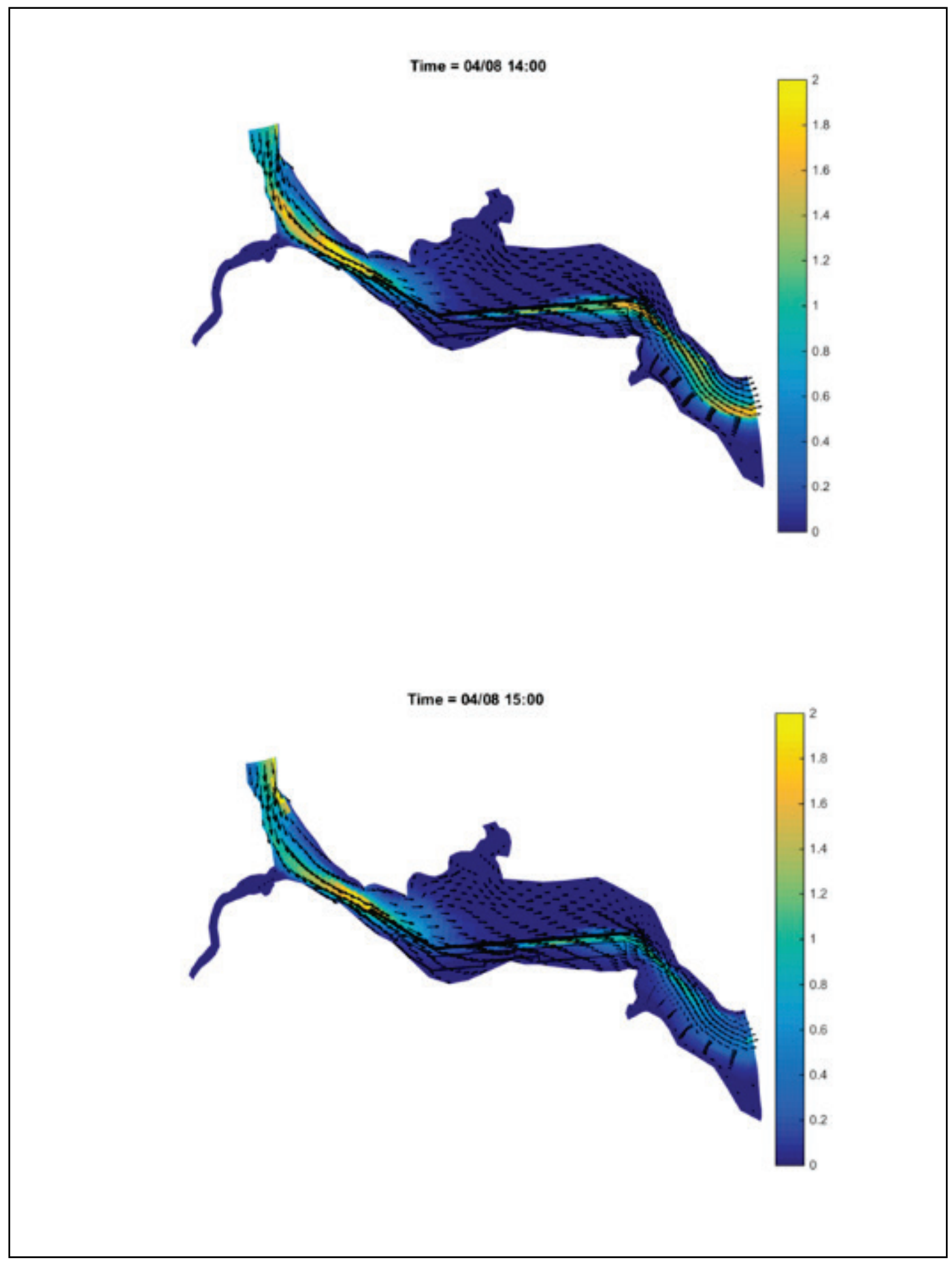


Figure 6-13. Bedload concentration $\left(\mathrm{g} / \mathrm{cm}^{3}\right)$ during ebb at 4/8 10:00 and 4/8 11:00.

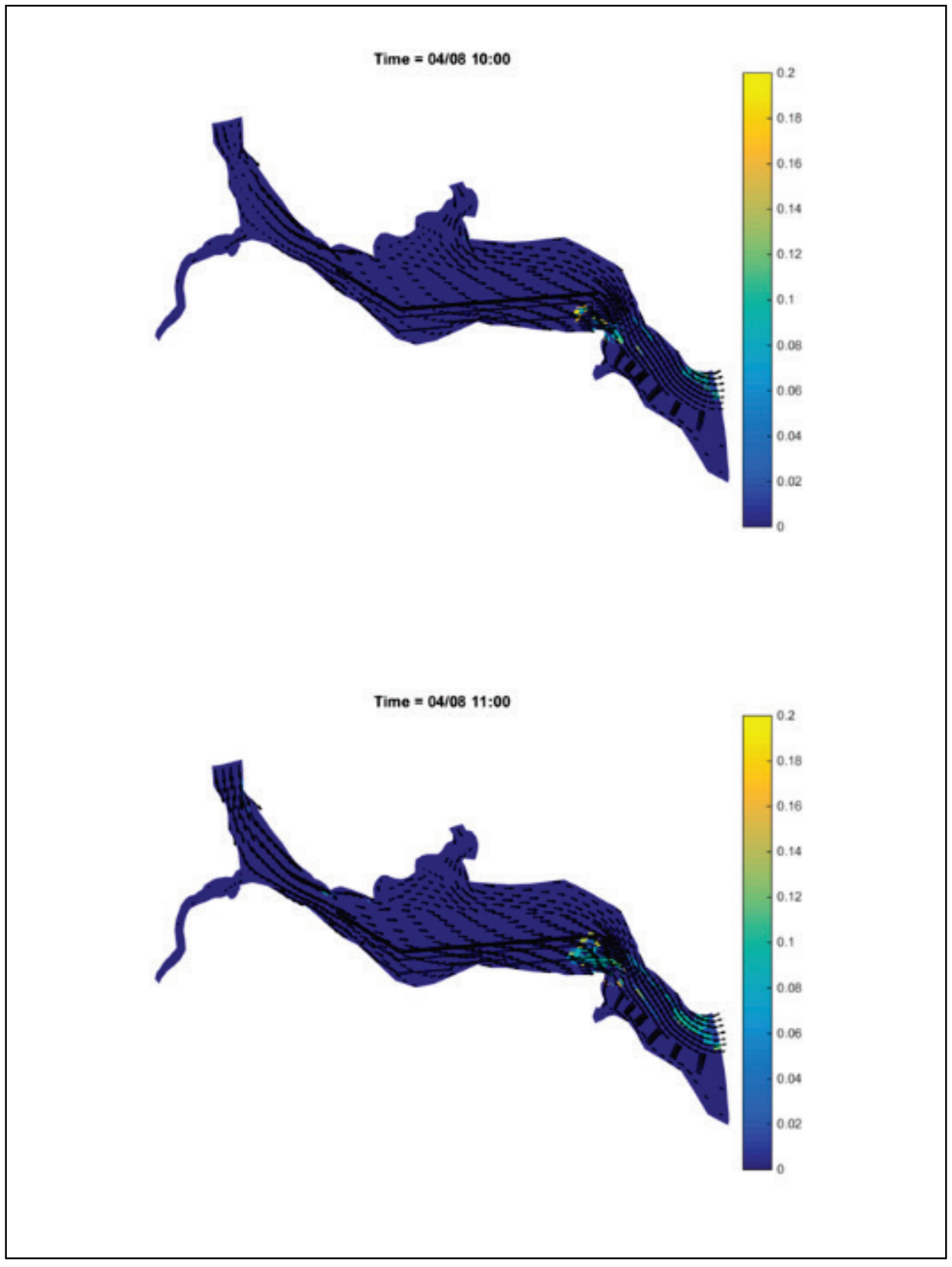


Figure 6-14. Bedload concentration $\left(\mathrm{g} / \mathrm{cm}^{3}\right)$ during ebb at 4/8 12:00 and 4/8 13:00.

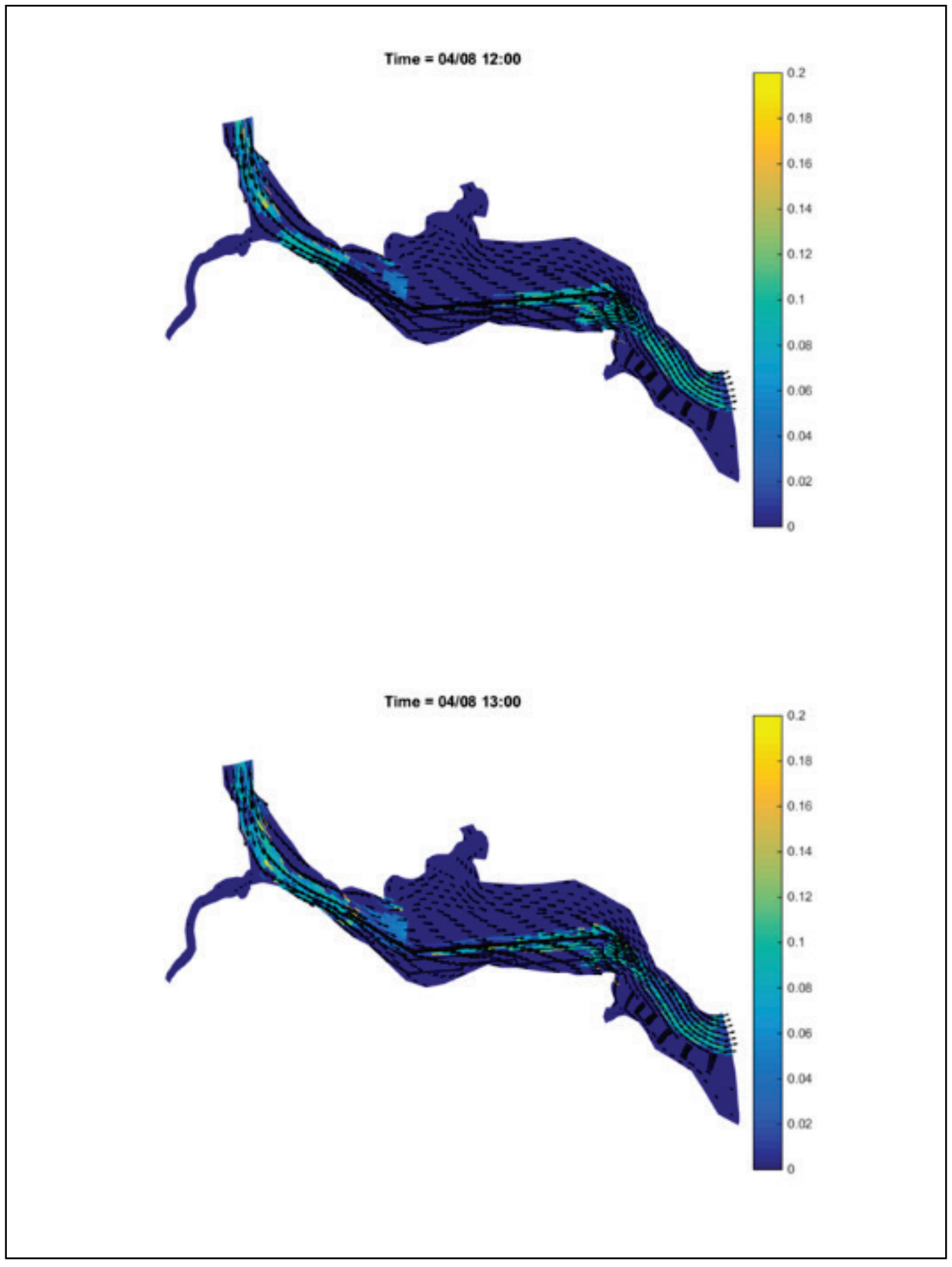


Figure 6-15. Bedload concentration $\left(\mathrm{g} / \mathrm{cm}^{3}\right)$ during ebb at 4/8 14:00 and 4/8 15:00.

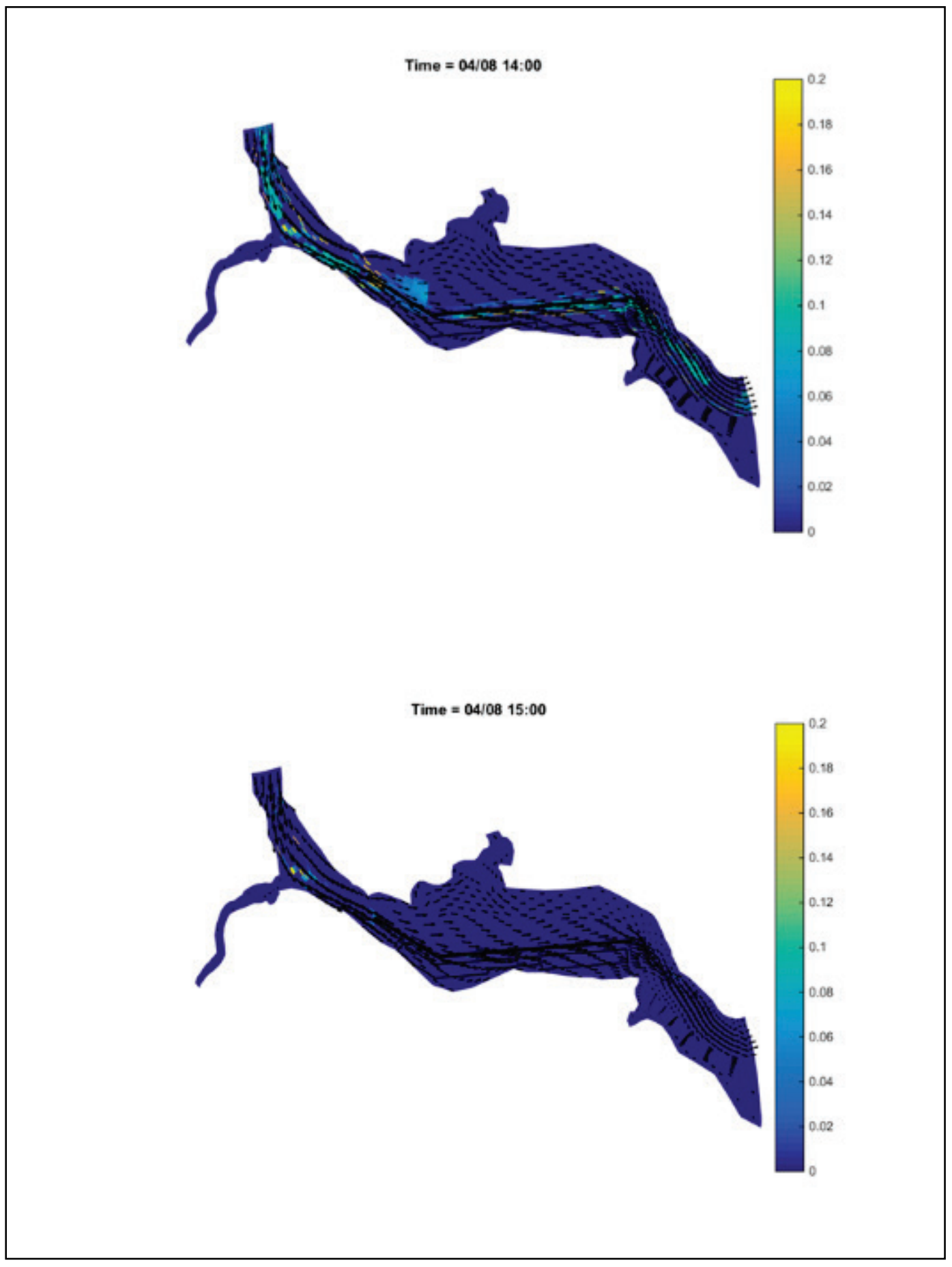


Figure 6-16. Bed thickness change $(\mathrm{cm})$ during flood at 4/8 05:00 and 4/8 06:00.

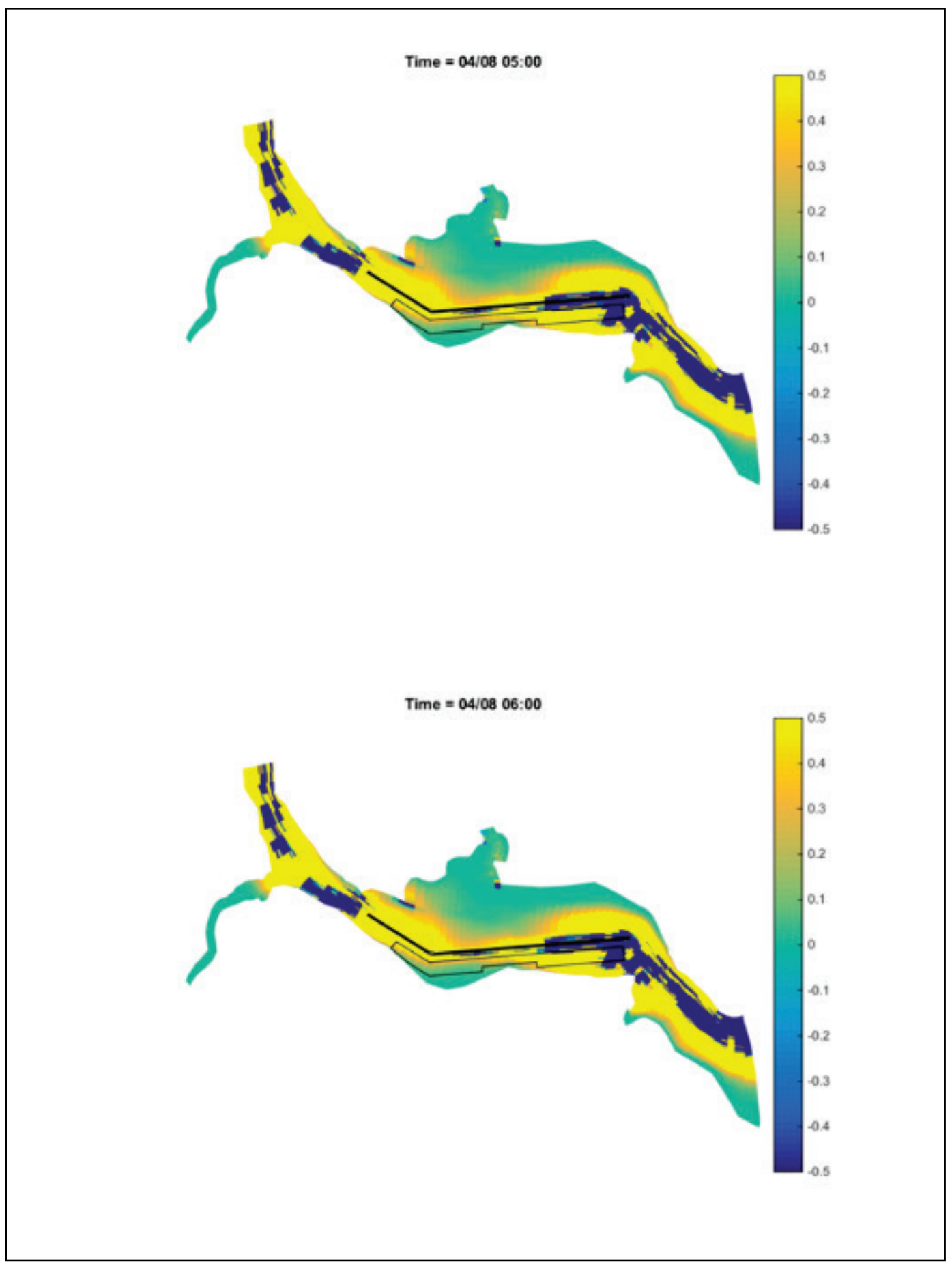


Figure 6-17. Bed thickness change (cm) during ebb at 4/8 12:00 and 4/8 13:00.

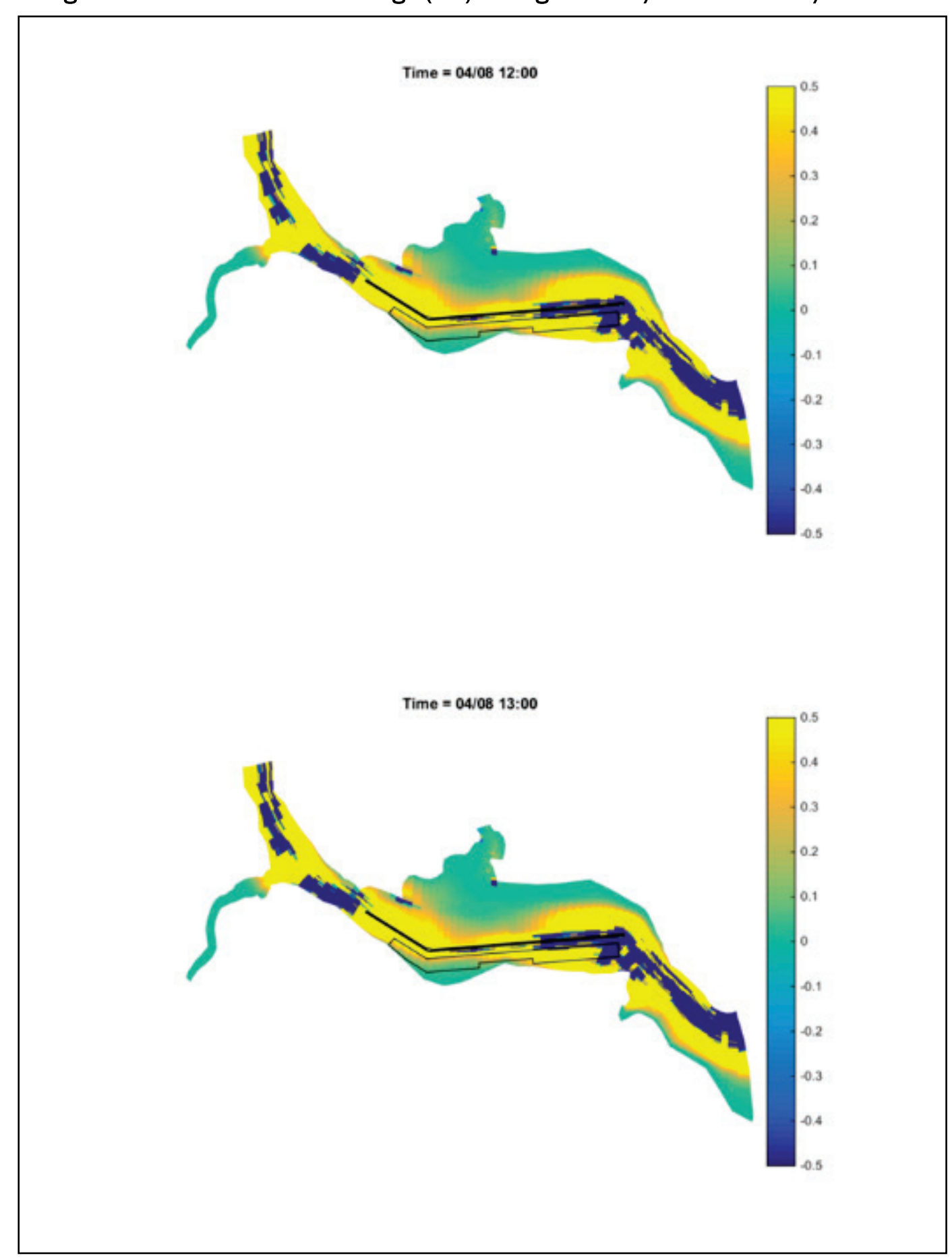

Bed changes suggest deposition over the shoal and erosion over the channel bed. Bed evolution includes all the sediment classes in the simulation. Note that data indicate shoaling in the channel. These simulations indicate that this shoaling is not caused by bed sediments but rather by upstream load, which is not simulated in this effort. To isolate 
the fate of placement sediments from native bed sediments, the mass of placement sediments deposited (classes $\mathrm{C}_{3}, \mathrm{C}_{4}, \mathrm{NC} 1, \mathrm{NC}_{2}$, and $\mathrm{NC}_{3}$ (Table 6-1)) were calculated separately. Figure 6-18 shows the mass per unit area $\left(\mathrm{g} / \mathrm{cm}^{2}\right)$ in bed layers. Most of placement sediments remain in the placement site. The placement sediments accumulated on the shoal on the opposite side of the channel and over shoals downstream of the placement site, indicating deposition. Little to no placement sediments were deposited in the channel due to high currents. Significant amounts of the eroded sediments move downstream outside the study area. To see the status of erosion and deposition of placement sediment, the net gain of sediment mass was calculated (Figure 6-19). This suggests erosion occurs at the Eastern portion of the placement mound. The sediments appear to have moved to the middle of the mound and across the channel as well. The sediments are also moved downstream of the mound and deposited in the southern shoals.

Figure 6-18. Sediment mass $\left(\mathrm{g} / \mathrm{cm}^{2}\right)$ in the bed layers at the end of the simulation period.

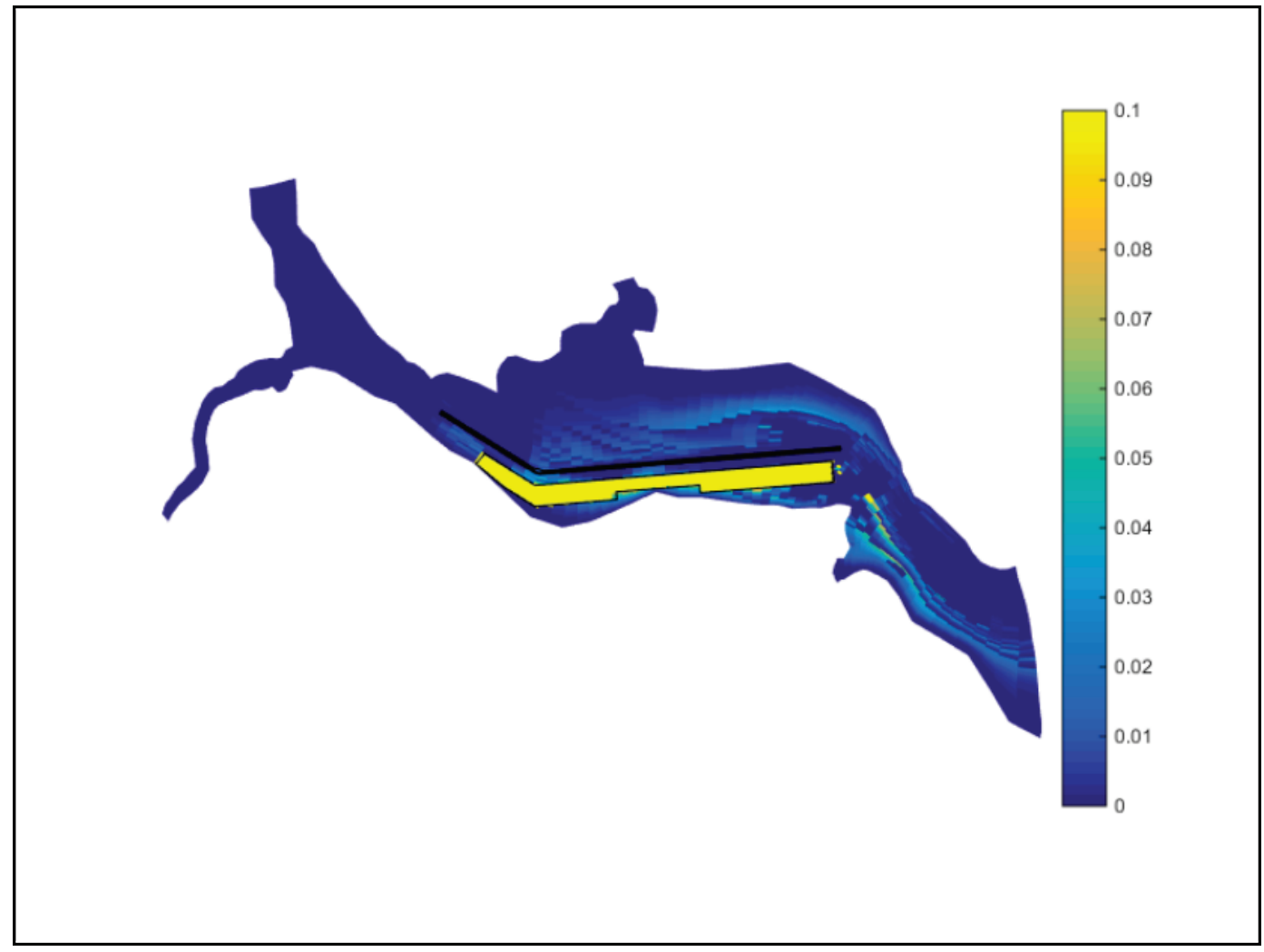


Figure 6-19. Net gain of sediments in the bed per unit area at final stage.

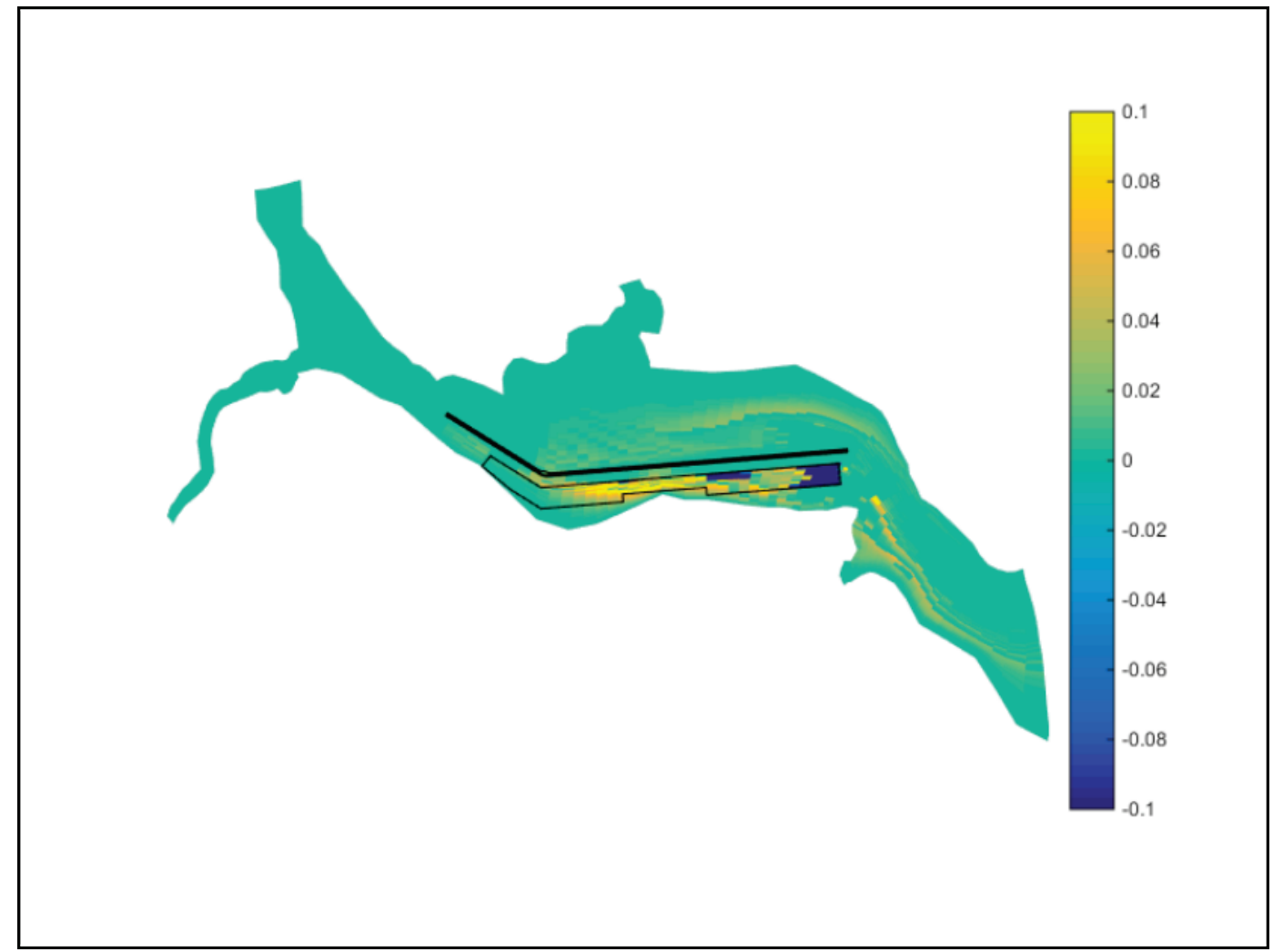

A large portion of the sediments from the placement mound are deposited downstream of the mound. To a lesser degree, deposition occurs the opposite side of the channel. Little or no deposition of mound sediment occurs in the channel due to the large currents, small settling velocities, and low critical shear stress for resuspension.

\subsection{Summary and discussion}

Sediment transport through suspended load and bedload sediments responds as expected to hydrodynamic conditions-stronger current results in higher concentration. While bedload concentration is localized and closely related to bottom stress, suspended sediment load demonstrates more dispersive behavior, indicating transport by advection as well as diffusion-both vertically and horizontally.

Due to bed processes including bed armoring, the interactions between native sediments and placement sediments are complex. Bed thickness change (Figures 6-7 and 6-8) reflects bed response of a composite of native 
bed and placement sediments. Bed response to hydrodynamic conditions appears more pronounced over the shoal than in the channel.

An amount of $75 \%$ of the placement mound is very small non-cohesive sediments $(\mathrm{D}=30 \mu \mathrm{m})$. This is associated with small settling velocities that result in the distribution downstream of the mound and across the channel. The sediment classes were based on the existing database and could have been oversimplified. This simulation did not include sediment supply from upstream of the James River. This simulation represents resuspension and redistribution of sediments over a 6-month period.

Modeling of sediment transport of bed sediments in the Dancing PointSwann Point Reach indicates that little of sediment from the placement mound moves into the channel. The fine-grained nature of these sediments (Table 6-1) precludes these small volumes of sediment from depositing in the channel where the currents are strong. Therefore, channel sedimentation is most likely caused by heavy upstream load of both sandy and fine sediment, which was not represented in these simulations. 


\section{Summary}

The purpose of this study was to determine the fate of material placed during dredging operations within the James River (Dancing Point-Swann Point reach) at a channel adjacent placement mound. This study focuses on the potential migration of the placement mound into the channel as well as the transport of sediment resuspended during placement. To accomplish this objective, five tasks were accomplished:

1. Hydrodynamic modeling using the GSMB Transport Modeling System

2. Sediment characterization using sediment samples collected from the James River

3. Pipeline discharge source term development

4. Modeling of sediment resuspended during placement

5. Determination of overall mound migration.

Based on the GSMB Transport Modeling System, an MB 3D finite difference model was set up for the James River and the adjacent Chesapeake Bay. The model was calibrated for water levels and salinity transport. The tidal current behavior was analyzed and qualitatively compared to NAO drogue survey data.

Modeling was performed to determine the suspended solids available for transport upon pipeline discharge from a cutterhead dredge. Two simple laboratory tests were conducted to validate the source term models. In general, the results of both the modeling and laboratory work seem to suggest the range between $3 \%$ and $7 \%$, which is in agreement with what is generally thought to occur in the field. These results were used to generate source terms for discharge at three specific locations within the placement area.

The fate of sediment resuspended during placement of the dredged material was modeled for 1 month using the PTM. Results suggest that the material released into the water column remains in the placement area or is transported out of the area of interest downstream. Results show some sediment pathways back towards the channel and that some of the material modeled does accumulate within the channel.

Mound migration was modeled using the LTFATE modeling system. Results indicate that little of sediment from the placement mound moves into the 
channel. The fine-grained nature of these sediments precludes these small volumes of sediment from depositing in the channel where the currents are strong. These results suggest that channel sedimentation is most likely caused by upstream sediment sources not represented in this study. 


\section{References}

Brandsma, M. G., and D. J. Divoky. 1976. Development of Models for Prediction of ShortTerm Fate of Dredged Material Discharged in the Estuarine Environment. Contract Report D-76-5. Prepared by Tetra Tech, Inc., Pasadena, CA. Vicksburg, MS: US Army Engineer Waterways Experiment Station.

Bunch, B. W., M. Channel, W. D. Corson, B. A. Ebersole, L. Lin, D. J. Mark, J. P. McKinney, S. A. Pranger, P. R. Schroeder, S. J. Smith, D. H. Tillman, B. A. Tracy, M. W. Tubman, and T. L. Welp. 2003. Evaluation of Island and Nearshore Confined Disposal Facility Alternatives, Pascagoula River Harbor Dredged Material Management Plan. Technical Report ERDC-03-3. Vicksburg, MS: US Army Engineer Research and Development Center.

Cerco, C., and T. Cole. 1994. Three-Dimensional Eutrophication Model of Chesapeake Bay. Technical Report EL-94-4. Vicksburg, MS: US Army Engineer Waterways Experiment Station.

Cerco, C. F, S.-C. Kim, and M. R. Noel. 2010. The 2010 Chesapeake Eutrophication Model. A Report to the US Environmental Protection Agency Chesapeake Bay Program and to the US Army Corps of Engineers Baltimore District. http://www.chesapeakebay.net/content/publications/cbp_55318.pdf

Chapman, R. S., B. H. Johnson, and S. R. Vemulakonda. 1996. Users Guide for the Sigma Stretched Version of $\mathrm{CH}_{3} D$-WES; A Three-Dimensional Numerical Hydrodynamic, Salinity and Temperature Model. Technical Report HL-96-21. Vicksburg, MS: US Army Engineer Waterways Experiment Station.

Chase, D. 1994. CDFATE User's Manual. Vicksburg, MS: US Army Engineer Waterways Experiment Station.

Cheng, N. S. 1997. "A Simplified Settling Velocity Formula for Sediment Particle." Journal of Hydraulic Engineering, ASCE 123(2): 149-152.

Doneker, R. L, and G. H. Jirka. 1991. An Expert System for Hydrodynamic Mixing Zone Analysis of Conventional and Toxic Submerged Single Port Discharges (CORMIX 1). EPA 600/3-90/o12. DeFrees Hydraulics Laboratory School of Civil and Environmental Engineering, Cornell University, Ithaca, NY. (Prepared for US EPA Office of Research and Development)

Doneker, R. L., J. D. Nash, and G. H. Jirka. 2004. "Pollutant Transport and Mixing Zone Simulation of Sediment Density Currents." Journal of Hydraulic Engineering 130(April 2004): 349-359.

Gailani, J. Z., T. C. Lackey, D. B. King, D. Bryant, S.-C. Kim, and D. J. Shafer. 2016. "Predicting Dredging-Associated Effects to Coral Reefs in Apra Harbor, GuamPart 1 Sediment Exposure Modeling." Journal of Environmental Management 168(1 March 2016): 16-26.

Hagen, S. C., J. J. Westerink, and R. L. Kolar. 2000. "One-Dimensional Finite Element Grids Based on a Localized Truncation Error Analysis.” International Journal for Numerical Methods in Fluids 32: 241-261. 
Harris, C.K., J. P. Rinehimer, and S.-C. Kim. 2012. "Estimates of Bed Stresses within a Model of Chesapeake Bay. Edited by M. L. Spaulding. Estuarine and Coastal Modeling, Proceedings of 12th International Conference, ASCE, 415-434.

Harris, C. K., J. P. Rinehimer, and S.-C. Kim. 2010. Representation of Bed Stresses within a Model of Chesapeake Bay. Special Report in Applied Marine Science and Ocean Engineering 424. Virginia Institute of Marine Science.

Havis Environmental. 1994. Mixing Zone Simulation Model for Dredge Overflow and Discharge into Inland and Coastal Water. Vicksburg, MS: US Army Engineer Waterways Experiment Station.

Hayes, D. F., and C. Je. 2000. DREDGE Module User's Guide. University of Utah.

Hayter E. J., R. S. Chapman, P. V. Luong, S. J. Smith, and D. B. Bryant. 2012. Demonstration of Predictive Capabilities for Fine-Scale Sedimentation Patterns within the Port of Anchorage, AK. Final Report prepared for U. S. Army District, Anchorage, AK.

Holton, J. W., J. B. Walsh, and J. C. Duchock. 2002. Navigation Project EvaluationDancing Point/Swann Point Channel. Final Report to NAO.

Jensen, R. E., M. A. Cialone, R. S. Chapman, B. E. Ebersole, M. Anderson, and L. Thomas. 2012. Modeling of Lake Michigan Storm Waves and Water Levels. ERDC/CHL TR-12-26. Vicksburg, MS: US Army Engineer Research and Development Center.

Johnson, B. H. 1990. User's Guide for Models of Dredged Material Disposal in Open Water. Technical Report D-90-5. Vicksburg, MS: US Army Engineer Waterways Experiment Station.

Kim, S.-C. 2013. "Evaluation of a Three-dimensional Hydrodynamic Model Applied to Chesapeake Bay through Long-Term Simulation of Transport Processes." Journal of the American Water Resources Association 49: 1078-1090.

Komen, G. J., L. Cavaleri, M. Donelan, K. Hasselmann, S. Hasselmann, and P.A.E.M. Janssen. 1994. Dynamics and Modelling of Ocean Waves. Cambridge: Cambridge University Press.

Lackey, T. C., and S. J. Smith. 2008. "Application of the Particle Tracking Model to Predict the fate of Dredged Suspended Sediment at the Willamette River." Proceedings Western Dredging Association Twenty-Eighth Annual Technical Conference, St. Louis, MO, USA.

Lin, L., Z. Demirbilek, H. Mase, J. Zheng, and F. Yamada. 2008. CMS-Wave: A Nearshore Spectral Wave Processes Model for Coastal Inlets and Navigation Projects. ERDC-CHL TR-08-13. Vicksburg, MS: US Army Engineer Research and Development Center.

Luong, P. V., and R. S. Chapman. 2009. Application of Multi-Block Grid and Parallelization Techniques in Hydrodynamic Modeling DoD High Performance Computing Modernization Program: User Group Conference (HPCMP-UGC), San Diego, CA. 
MacDonald, N. J., M. H. Davies, A. K. Zundel, J. C. Howlett, Z. Demirbilek, J. Z. Gailani, T. C. Lackey, and J. Smith. 2006. PTM: Particle Tracking Model: Report 1; Model Theory, Implementation, and Example Applications. ERDC/CHL TR-o620. Vicksburg, MS: US Army Engineer Research and Development Center.

McNeil, J., C. Taylor, and W. Lick. 1996. "Measurements of Erosion of Undisturbed Bottom Sediments with Depth." Journal of Hydraulic Engineering 122(6): 316324 .

Rosati, J. D., and N. C. Kraus. 1999. Sediment Budget Analysis System (SBAS). CETNIV-20. Vicksburg, MS: US Army Engineer Research and Development Center.

Saha S., S. Moorthi, H-L. Pan, X. Wu, J. Wang, S. Nadiga, P. Tripp, R. Kistler, J. Woollen, D. Behringer, H. Liu, D. Stokes, R. Grumbine, G. Gayno, J. Wang, Y-T. Hou, H-Y. Chuang, H-MH. Juang, J. Sela, M. Iredell, R. Treadon, D. Kleist, P. V. Delst, D. Keyser, J. Derber, M. Ek, J. Meng, H. Wei, R. Yang, S. Lord, H. V. D. Dool, A. Kumar, W. Wang, C. Long, M. Chelliah, Y. Xue, B. Huang, J-K. Schemm, W. Ebisuzaki, R. Lin, P. Xie, M. Chen, S. Zhou, W. Higgins, C-Z. Zou, Q. Liu, Y. Chen, Y. Han, L. Cucurull, R. W. Reynolds, G. Rutledge, and M. Goldberg. 2010. "The NCEP Climate Forecast System Reanalysis.” Bull. Amer. Meteor. Soc. 91: 10151057. doi:10.1175/2010bams3001.1

Smith, J. M., D. T. Resio, and A. K. Zundel. 1999. STWAVE: Steady-State Spectral Wave Model; Report 1: User's Manual for STWAVE Version 2.o. Instructional Report CHL-99-1. Vicksburg, MS: US Army Engineer Research and Development Center.

Smith, S. J., and C. Friedricks. 2010. "Size Distributions and Settling Velocities of Cohesive Flocs and Suspended Sediment Aggregates in a Trailing Suction Hopper Dredge Plume." Continental Shelf Research. doi:10.1016/j.crs.2010.04.002

Soulsby, R. L. 1997. Dynamics of Marine Sands. London, UK: Thomas Telford.

van Rijn, L. C. 1984. "SEDIMENT TRANsport. Part I: Bed Load Transport.” J. Hydraul. Eng. 110(10): 1431-1456.

Zundel, A. K. 2000. Surface-Water Modeling System Reference Manual. Provo, UT: Brigham Young University, Environmental Modeling Research Laboratory. 


\section{Unit Conversion Factors}

\begin{tabular}{|l|c|l|}
\hline Multiply & By & To Obtain \\
\hline cubic feet & 0.02831685 & cubic meters \\
\hline cubic inches & $1.6387064 \mathrm{E}-05$ & cubic meters \\
\hline cubic yards & 0.7645549 & cubic meters \\
\hline feet & 0.3048 & meters \\
\hline knots & 0.5144444 & meters per second \\
\hline microinches & 0.0254 & micrometers \\
\hline microns & $1.0 \mathrm{E}-06$ & meters \\
\hline miles (nautical) & 1,852 & meters \\
\hline miles (US statute) & $1,609.347$ & meters \\
\hline miles per hour & 0.44704 & meters per second \\
\hline mils & 0.0254 & millimeters \\
\hline pounds (force) & 4.448222 & newtons \\
\hline quarts (US liquid) & $9.463529 \mathrm{E}-04$ & cubic meters \\
\hline slugs & 14.59390 & kilograms \\
\hline square feet & 0.09290304 & square meters \\
\hline square inches & $6.4516 \mathrm{E}-04$ & square meters \\
\hline square miles & $2.589998 \mathrm{E}+06$ & square meters \\
\hline square yards & 0.8361274 & square meters \\
\hline yards & 0.9144 & meters \\
\hline
\end{tabular}




\section{Acronyms and Abbreviations}

$\begin{array}{ll}\text { 2D } & \text { two-dimensional } \\ \text { 3D } & \text { three-dimensional } \\ \text { CBBT } & \text { Chesapeake Bay Bridge Tunnel } \\ \text { CDFATE } & \text { Continuous Discharge Fate } \\ \text { CH3D } & \text { Curvilinear Hydrodynamic in 3-dimensional } \\ \text { CH3D } & \text { Curvilinear Hydrodynamics in Three Dimension } \\ \text { CH3D-WES } & \text { Curvilinear Hydrodynamic in 3-dimensional, Waterways } \\ \text { DIFCD } & \text { Experiment Station } \\ \text { DM } & \text { DIsposal From a Continuous Discharge } \\ \text { GSMB } & \text { Geophysical Scale Multi-Block } \\ \text { HAMELS } & \text { Harmonic Analysis, Method of Least Squares } \\ \text { LTFATE } & \text { Longterm Fate } \\ \text { MB } & \text { multi-block } \\ \text { NAO } & \text { Norfolk District } \\ \text { NOAA } & \text { National Oceanic and Atmospheric Administration } \\ \text { OWI } & \text { Ocean Weather, Inc } \\ \text { PTM } & \text { Particle Tracking Model } \\ \text { USACE } & \text { US Army Corps of Engineers } \\ \text { USGS } & \text { US Geological Survey } \\ \text { VMRC } & \text { Virginia Marine Resources Commission } \\ \text { WQ } & \text { water quality } \\ \end{array}$




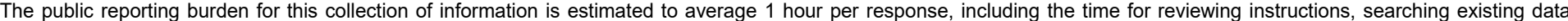

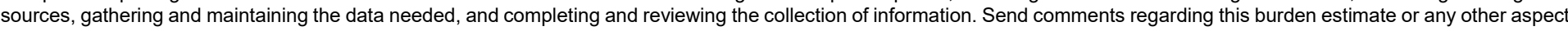

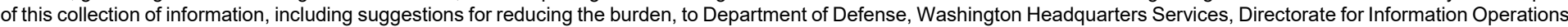

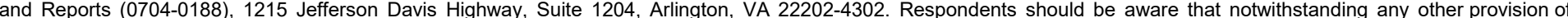
law, no person shall be subject to any penalty for failing to comply with a collection of information if it does not display a currently valid OMB control number. PLEASE DO NOT RETURN YOUR FORM TO THE ABOVE ADDRESS.

\begin{tabular}{l|l|l}
\hline 1. REPORT DATE & $\begin{array}{l}\text { 2. REPORT TYPE } \\
\text { Final Report }\end{array}$ & 3. DATES COVERED (From - To) \\
September 2020 & Dinal
\end{tabular}

\section{TITLE AND SUBTITLE}

Hydrodynamic and Sediment Transport Modeling for James River Dredged Material Management 5a. CONTRACT NUMBER

5b. GRANT NUMBER

5c. PROGRAM ELEMENT NUMBER

5d. PROJECT NUMBER

448771

5e. TASK NUMBER

5f. WORK UNIT NUMBER

8. PERFORMING ORGANIZATION REPORT

NUMBER

US Army Engineer Research and

Development Center

3909 Halls Ferry Road

ERDC TR-20-21

Vicksburg, MS 39180-6199

\section{Development Center}

3909 Halls Ferry Road

Vicksburg, MS 39180-6199

\section{SPONSORING/MONITORING AGENCY NAME(S) AND ADDRESS(ES)}

US Army Corps of Engineers

Washington, DC 20314-1000

\section{SPONSOR/MONITOR'S ACRONYM(S) USACE}

\section{SPONSOR/MONITOR'S} REPORT NUMBER(S)

\section{DISTRIBUTION/AVAILABILITY STATEMENT}

Approved for public release; distribution is unlimited.

\section{SUPPLEMENTARY NOTES}

\section{ABSTRACT}

The fate of material placed during dredging operations within the James River (Dancing Point-Swann Point reach) at a channel adjacent placement mound was modeled within this work. The study focuses on the potential migration of the placement mound into the channel as well as the transport of sediment resuspended during placement. A select combination of US Army Engineer Research and Development-developed models was utilized in this work to appropriately simulate hydrodynamic conditions, pipeline discharge near field suspended sediment estimates, far field transport of the pipeline discharge source term, and mound migration. Results show that the material released into the water column during placement remains in the placement area or is transported out of the area of interest downstream. A small fraction of sediment from the placement mound migrates into the channel after placement. The fine-grained nature of these sediments precludes these small volumes of sediment from depositing in the channel where the currents are strong.

\section{SUBJECT TERMS}

Dredging, Dredging spoil, Hydrodynamics, Hydrologic models, James River (Va.), Sedimentation and deposition, Sediment transport, Suspended sediments

\begin{tabular}{|c|c|c|c|c|c|}
\hline \multicolumn{3}{|c|}{ 16. SECURITY CLASSIFICATION OF: } & \multirow{3}{*}{$\begin{array}{l}\text { 17. LIMITATION OF } \\
\text { ABSTRACT } \\
\text { SAR }\end{array}$} & 18. NUMBER & \\
\hline a. REPORT & b. ABSTRACT & c. THIS PAGE & & $\begin{array}{l}\text { OF } \\
\text { PAGES }\end{array}$ & \\
\hline Unclassified & Unclassified & Unclassified & & 104 & $\begin{array}{l}\text { 19b. TELEPHONE NUMBER (Include area code) } \\
601-634-3552\end{array}$ \\
\hline
\end{tabular}

